九州大学学術情報リポジトリ

Kyushu University Institutional Repository

\title{
Biostratigraphy of the Upper Cretaceous Santonian Stage in Northwestem Hokkaido
}

Toshimitsu, Seiichi

Faculty of Sciences, Kyushu University

https://doi.org/10.5109/1546322

出版情報：九州大學理學部紀要：Series D, Geology. 26 (2)，pp. 125-192，1988-01-20. Faculty of Science, Kyushu University バージョン：

権利関係 : 
Mem. Fac. Sci., Kyushu Univ., Ser, D, Geol., Vol XXVI, No. 2, pp. 125-192, text-figs. 1-27, tables 1-8, plates 23-29, January 20, 1988

\title{
Biostratigraphy of the Upper Cretaceous Santonian Stage in Northwestern Hokkaido
}

\author{
Seiichi ToshIMITsU
}

\begin{abstract}
This paper describes the biostratigraphy of the upper part of the Upper Yezo Group (Upper Cretaceous) exposed in the Haboro and adjacent areas of northwestern Hokkaido to define the Santonian Stage in Japan by establishing a revised scheme of zonation.

The Upper Yezo Group in the Haboro area is made up mainly of sandstone, siltstone and claystone, and is divided on the basis of predominant lithology into the Lower, Middle and Upper Haborogawa Formations. This lithostratigraphic division can be also applicable to the northerly adjacent Chikubetsu and southerly neighbouring Kotanbetsu and Obira areas. Some of relatively thick sandstone interbeds in the mudstone succession are laterally traceable as marker beds from the Chikubetsu area to the Obira area.

Of these three formations, the Middle and Upper Haborogawa Formations which encompasses the so-called Santonian Stage are almost continuously exposed and yield abundant fossils. As a result of a biostratigraphic study of these two formations, the following four inoceramid zones were recognized; in ascending order, the Inoceramus uwajimensis-I. mihoensis Zone, the I. amakusensis Zone, the Platyceramus japonicus Zone, the Sphenoceramus orientalis Zone and the S. schmidti Zone. A subzone characterized by the association of $S$. sanrikuensis, $S$. cristatus sp. nov. and Inoceramus (Cordiceramus) kanmerai is discriminated in the upper main part of the $P$. japonicus Zone. On the other hand, the successions studied can be divided into two ammonite zones based on the Texanitinae, i.e. the Texanites collignoni-T. quinquenodosus Zone below and the Plesiotexanites kawasakii-P. pacificus Zone above. It is also suggested that the latter zone is subdivided into the subzones of $T$. amakusensis (lower), Protexanites (Anatexanites) fukazawai-P. (P.) bontanti shimizui and/or Submortoniceras cf. condamyi (upper). The T. collgnoni-T. quinquenodosus Zone occupies the basal part of the I. amakusensis Zone, and is correlated with the Lower Santonian. The occurrences of Submortoniceras cf. condamyi, Menabites mazenoti and Globotruncana arca from the Platyceramus japonicus Zone indicate that this zone should be regarded as the Lowest Campanian. Consequently the zone of $I$. amakusensis corresponds precisely to the Santonian.
\end{abstract}

\section{Introduction}

The Santonian Stage of Japan has hitherto been divided into two inoceramid zones, the Inoceramus amakusensis Zone below and the Platyceramus japonicus Zone above. The zonal index species are, however, endemic, and short-ranged and widespread ammonites are rather few in the Santonian of Japan. On account

Manuscript received July 20, 1987. 
of these facts not only the inter-regional correlation of the Santonian Stage but also the setting of the stage boundary between the Santonian and the Campanian have remained unsettled. MATSUMOTO and TASHIRo (1982) integrated the macrobiostratigraphy (MATSUmoto, 1982; MATsumoto et al., 1982; TASHIRo and KozAI, 1982) and micro-biostratigraphy (OKAMURA et al., 1982; TAKAYANAGI et al., 1982 ) of the Cretaceous sequence of the Monobe area, Shikoku, and suggested that the Santonian-Campanian boundary in terms of the micro-biostratigraphy may be placed within the zone of Platyceramus japonicus, which had been regarded as the Upper Santonian. Matsumoto and Takahashi (1986) reported the occurrence of Menabites mazenoti CollignoN, a Middle Campanian species in Madagascar, from the zone of Platyceramus japonicus in the Migino-sawa, a branch of the Haboro River (Toshimitsu, 1985). Therefore the idea that at least part of the Platyceramus japonicus Zone belongs to the Campanian is supported not only by micro-fossils but also by an ammonite.

Recently, KENNEDY (1983 and 1984a) restudied the ammonite faunas of the Coniacian, Santonian and Campanian stratotypes in the Aquitaine Basin, France, and clarified that the previous ammonite records from the Aquitaine Basin should be treated with great caution because of insufficient taxonomic revision, and that the zonation based on the ammonites faunas from the Upper Coniacian to the Lower Campanian in that area is practically difficult because of their poor occurrences. Under these circumstances, the Subcommission on Cretaceous Stratigraphy of IUGS held a Symposium at Copenhagen in 1983 and proposed the tentative stratotypes of those stages and their boundaries. Of course, these proposals should be examined thoroughly by later studies.

The Upper Cretaceous succession exposed in northwestern Hokkaido provides good material for a study of this type, in particular to get evidence suitable for the definition and zonation of the Santonian Stage.

For these five years I have carried out field work along numerous routes in the Chikubetsu, Haboro, Kotanbetsu and Obira areas (Fig. 1) to examine in detail the stratigraphic successions of the upper part of the Middle Yezo Group and the Upper Yezo Group and at the same time to obtain samples of both micro- and mega-fossils, with special reference to the sequence which encompasses the zone of Platyceramus japonicus.

\section{Lithostratigraphic summary}

The Cretaceous deposits in the Haboro to the Obira areas consist of the Middle and Upper Yezo Groups and the disconformably overlying Hakobuchi Group in the Chikubetsu area. The strata of the Middle and Upper Yezo Groups in the study area trend north-northwest to south-southwest, as shown in Fig. 1. The Middle Yezo Group crops out on the northeastern side and the Upper Yezo Group is progressively younger towards the west, although there are some repetition of beds due to folding and faulting. The two groups are well exposed, from north to south, along the Sankebetsu-gawa, a tributary in the upper reaches of the Chikubetsu River, the Detofutamata-gawa, Nakanofutamata-gawa, Sakasagawa, Otodo-zawa and, Chimei-zawa of the Haboro River, and the upper reaches 


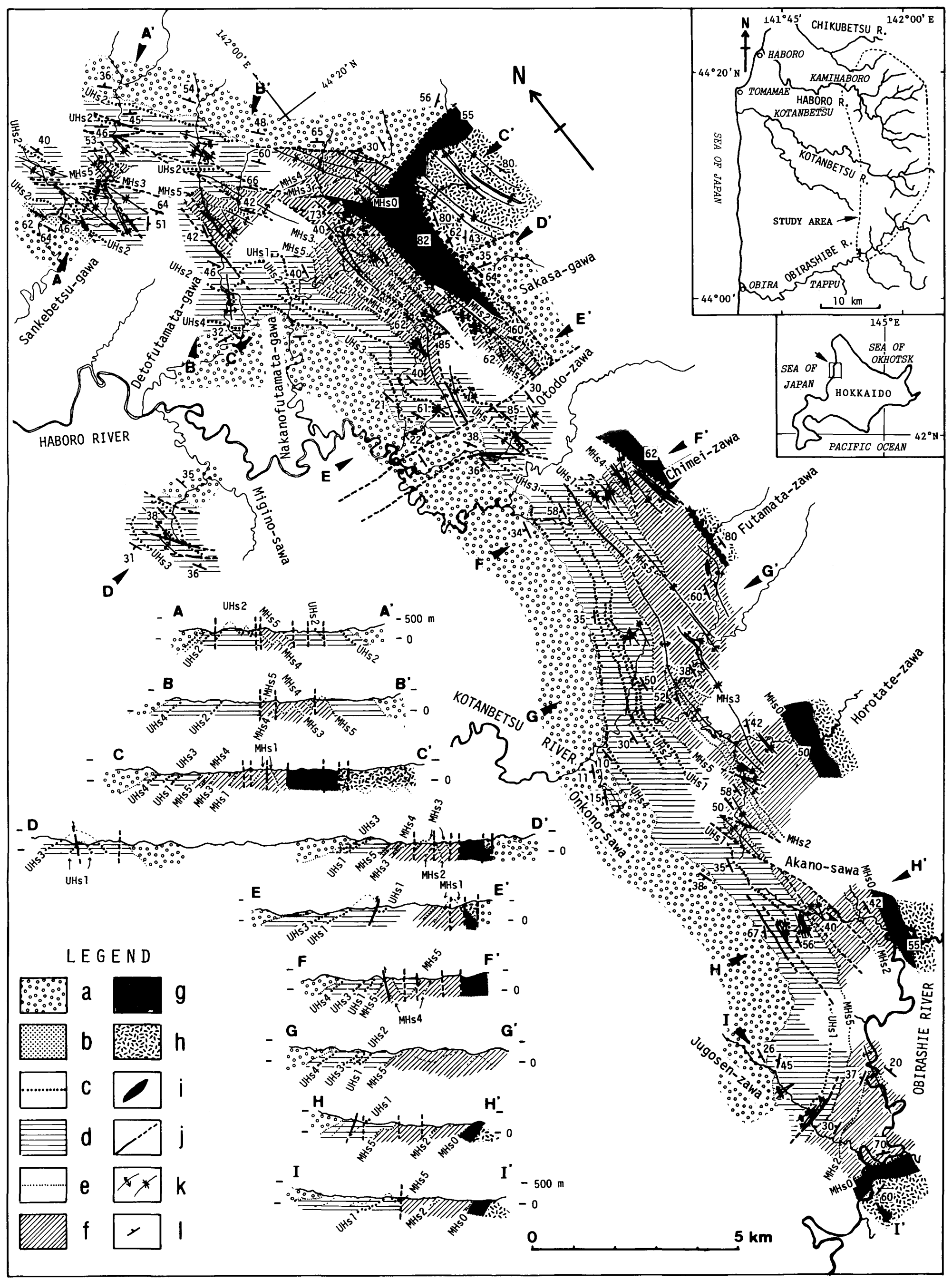

Fig. 1. Geological map and profiles of the Chikubetsu, Haboro, Kotanbetsu and Obira areas, northwest Hokkaido. Inset at the upper right corner is the index map showing the area studied.

legend; a: Tertiary, b: Pankezawa Formation (Hakobuchi Group), c: sandstone members of the Upper Haborogawa Formation, d: Upper Haborogawa Formation, e: sandstone members of the Middle Haborogawa Formation, f: Middle Haborogawa Formation, g: Lower Haborogawa Formation, $h$ : Shirochi Formation, i: basic dyke and sill rocks, $j$ : fault, $\mathrm{k}$ : fold, l: strike and dip. 


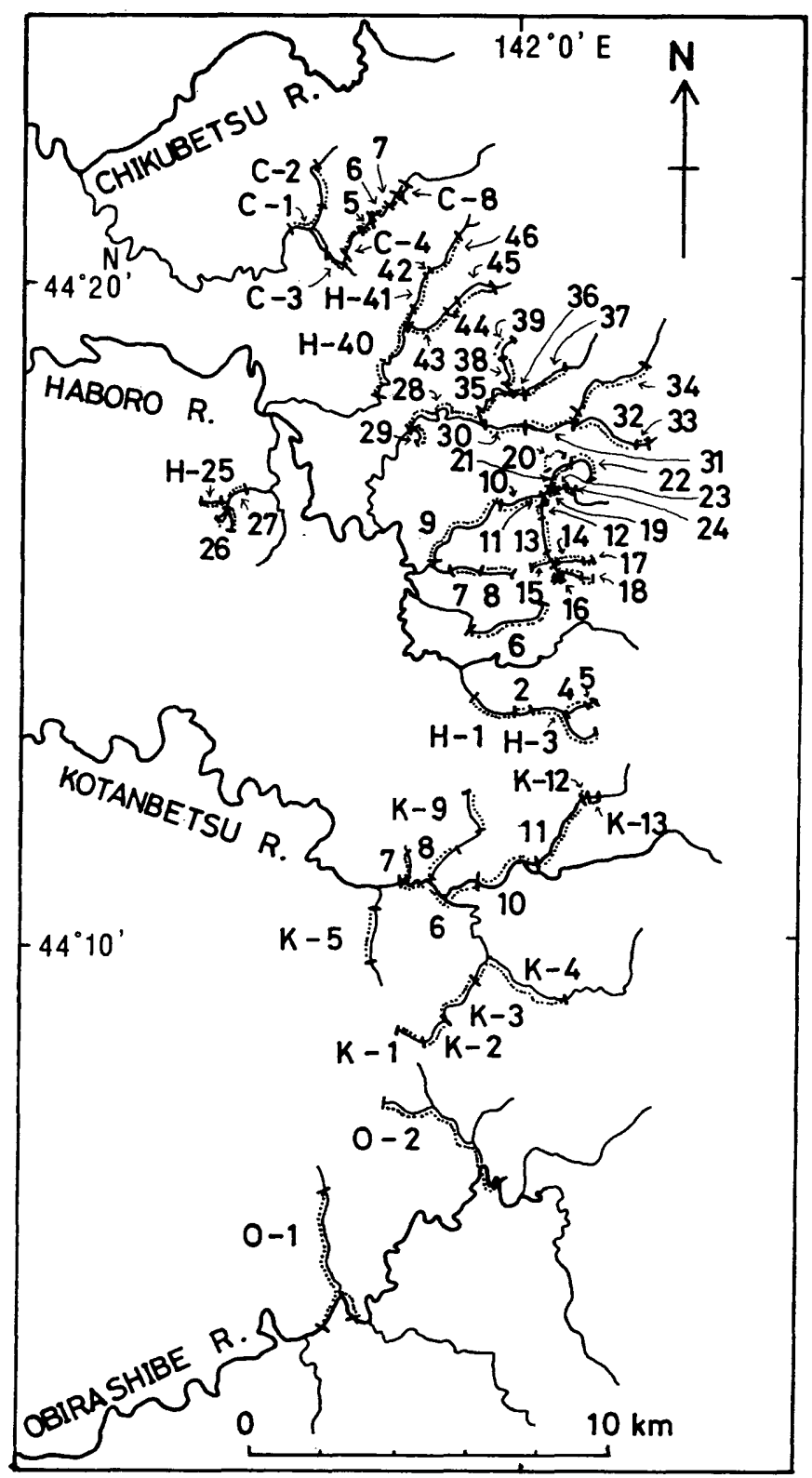

Fig. 2. Index map of the Chikubetsu, Haboro, Kotanbetsu and Obira areas indicating the routes $\mathrm{C}-1$ to $\mathrm{O}-2$ along which the Cretaceous sequences were measured and illustrated in Fig. 3.

of the Kotanbetsu River and the Akano-sawa and the Jugosen-zawa, western branches of the Obirashibe River (Figs. 1, 2, 3). The Upper Yezo Group crops out again as dome shaped inlier surrounded by the Neogene Tertiary in the Migino-sawa, a tributary of the Haboro River to the west.

The geology of the Upper Cretaceous areas in northwestern Hokkaido, such as the Chikubetsu, Haboro, Kotanbetsu and Obira areas, was mapped and described 
by several workers. TANAKA's (1963) lithostratigraphic subdivision in the Obira area has often been referred by the subsequent workers, but it is difficult to apply it to the northerly adjacent Kotanbetsu and Haboro areas. Meanwhile, I divided the Cretaceous deposits of the Haboro area into four formations, paying attention to the sedimentary cycle and associated sandstone members intercalated in the mudstone (Toshimitsu, 1985). As my investigation proceeded, it has become clear that this division is available also to the upper part of the Middle Yezo Group and the Upper Yezo Group exposed in the southerly adjacent Kotanbetsu and Obira areas (Fig. 3).

The stratigraphy of the Yezo and Hakobuchi Groups exposed in the study area is described briefly below. The full descriptions of the stratotype areas are given by Toshimitsu (1985) and MATsuno and Kino (1960), respectively.

\section{A. Middle Yezo Group}

(1) Shirochi Formation (corresponding to the Saku Formation of MATsumoto, 1942a) : mudstone with many interbeds of turbidite sandstone; about $830 \mathrm{~m}$ in thickness. This formation can be divided into the Inoceramus hobetsensis Zone and the $I$. teshioensis Zone in the ascending order.

\section{B. Upper Yezo Group}

(2) Lower Haborogawa Formation: clayey mudstone predominant, with frequent intercalations of acidic tuff and some thin interbeds of sandstone; about $950 \mathrm{~m}$ thick in the Haboro area and $350 \mathrm{~m}$ in the Obira area. This formation can be referred to as the uppermost part of the Inoceramus teshioensis Zone and the superjacent I. uwajimensis-I. mihoensis Zone.

(3) Middle Haborogawa Formation: largely silty mudstone with several sandstone interbeds, each several meters thick; about $800 \mathrm{~m}$ thick in the Haboro area and approximately $1000 \mathrm{~m}$ in the Obira area. This formation belongs to the upper part of the Inoceramus uwajimensis-I. mihoensis Zone and the Inoceramus amakusensis Zone.

(4) Upper Haborogawa Formation: Consisting of at least three, 100 to $250 \mathrm{~m}$ thick, coarsening-upward sequences (called "Haboro cycle" by OKADA and MAтsumoто, 1969) which begin with mudstone, passing through bioturbated siltstone to end with a 5 to $20 \mathrm{~m}$ thick bed of cross-laminated glauconitic sandstone. Some sandstones are tuffaceous; at least $850 \mathrm{~m}$ thick. I recognized the fourth cycle, which grades upward from clayey mudstone into a several-meter thick tuffaceous sandstone in the uppermost part of this formation exposed along the Detofutamata-gawa, Nakanofutamata-gawa, Chimei-zawa and Kotanbetsu River. This formation ranges biostratigraphically from the upper part of the Inoceramus amakusensis, Platyceramus japonicus, Sphenoceramus orientalis and S. schmidti Zones.

\section{Hakobuchi Group}

(5) Pankezawa Formation: consisting of large-scale cross-stratified coarsegrained sandstone, tuffaceous claystone and acidic tabular-bedded tuff; about $130 \mathrm{~m}$ thick. This formation yielded Baculites cf. occidentalis MEEK, Canadoceras 


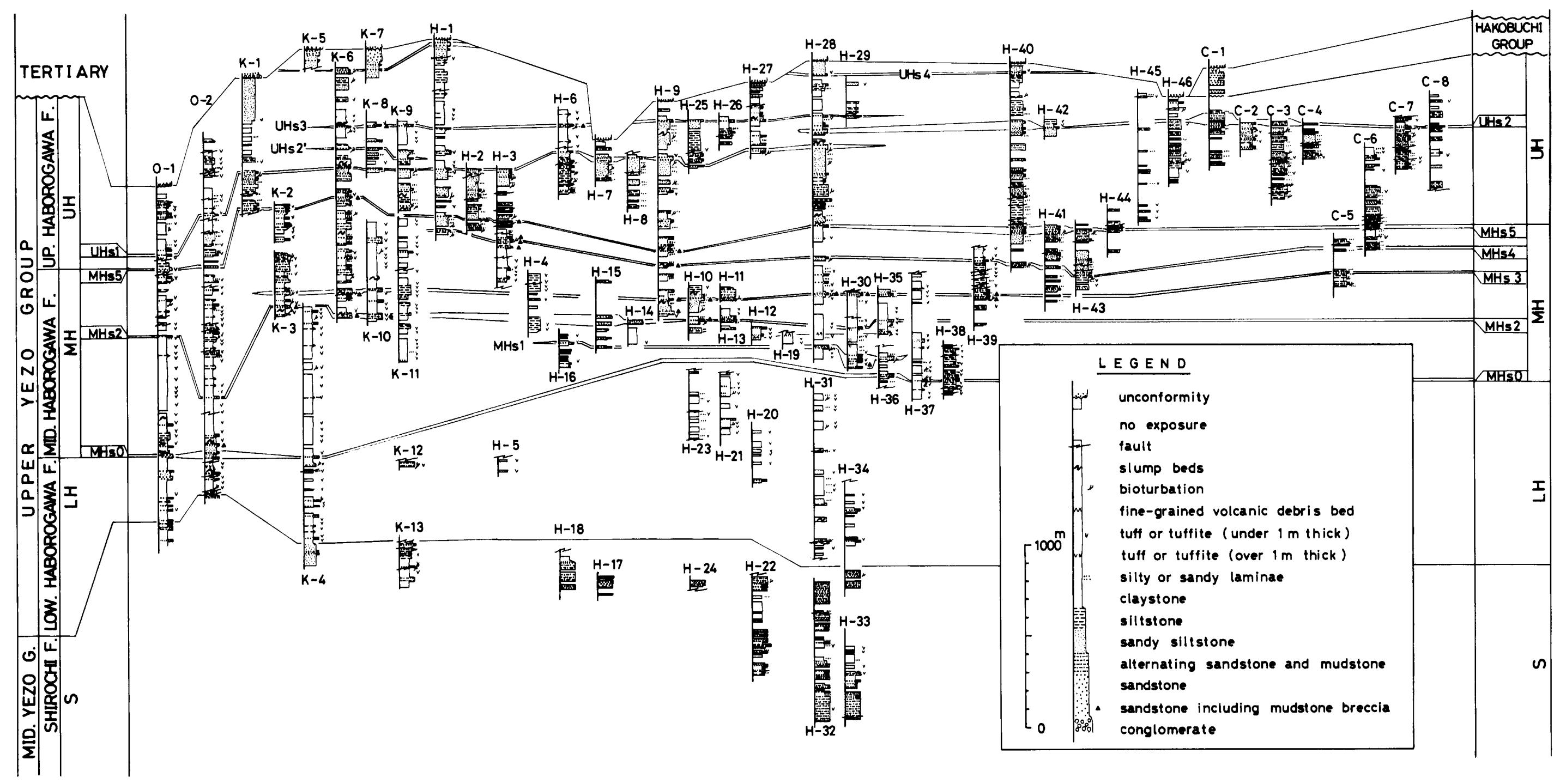

Fig. 3. Stratigraphic columnar sections of the uppermost part of the Middle Yezo Group, the Upper Yezo Group and the Hakobuchi Group in the Chikubetsu, Haboro, Kotanbetsu and Obira areas, northwest Hokkaido. 
multicostatum MATSUмото, Ryugasella cf. ryugasensis WRIGHT and MATSUMoto, cf. Pachydiscus ootacodensis (STOLICZKA) and Inoceramus cf. balticus toyajoanus NAGAO and MATSUMoto (HATTORI, 1965). This assemblage suggests the upper part of the Campanian.

Among these formations, the Middle and Upper Haborogawa Formations are distributed in a continuous belt from the Chikubetsu area to the Obira area, and several to $20 \mathrm{~m}$-thick sandstone interbeds can be traced throughout these areas as key beds. Therefore, these sandstone beds are named MHs0 to MHs5 in the Middle Haborogawa Formation and UHs1 to UHs3 in the Upper Haborogawa Formation (Toshimitsu, 1985). Furthermore the newly named UHs2' and UHs4 sandstone beds are also useful as a marker bed. The former is situated at the top of the second cycle in the Upper Haborogawa Formation of the Kotanbetsu area, and is stratigraphically equivalent to the UHs2 of the Haboro area. The latter lies at the upper part of the fourth cycle in the Upper Haborogawa Formation of the Haboro and Kotanbetsu areas.

\section{Biostratigraphy of the so-called Santonian Stage in the Haboro and adjacent areas}

The Cretaceous deposits in the study area yield abundant fossils of various kinds such as mollusca, simple corals, echinoids, crustaceans, fish scales and teeth, and plant remains. I examined in detail the biostratigraphic sequence of the so-called Santonian Stage including the zones of Inoceramus amakusensis and Platyceramus japonicus by means of inoceramid bivalves and ammonoids. The identified species and their locations of occurrence are shown in Tables 1 to 8, and their stratigraphic horizons are plotted on the measured columnar sections shown in Figs. 7 to 15, with locailty maps (Figs. 16 to 26). In this paper the columnar sections are numbered as follows (see Figs. 2, 3): H-40 to H-46: Detofutamata-gawa, H-28 to H-39: Nakanofutamata-gawa, H-25 to H-27: Miginosawa, H-7 to H-10: Sakasa-gawa, H-6: Otodo-zawa, H-1 to H-5: Chimei-zawa, K-1 to K-13: Kotanbetsu River, O-1 and O-2: Obirashibe River.

In these columnar sections, the line drawn from the first occurrence to the last occurrence of a given species is tentatively regarded as a local range of that species. After these local ranges of the identified species in all of the measured sections were acquired by this operation, they were unified into a generalized columnar section (Figs. 3, 27a-f) compiled on the basis of the correlation by means of the aformentioned sandstone marker beds such as MHs and UHs, which can be regarded as approximately isochronous planes. Therefore, the total range of individual species was deduced by linking the lowest and highest levels of their occurrences in the generalized columnar section. Furthermore, the biostratigraphic ranges of inocerami and selected ammonites yielded from the two routes in the Saku area, about $50 \mathrm{~km}$ north of the Haboro area are also taken as supplementary data (Figs. 4a, b).

As the results of the detailed examination of the assemblages and stratigraphic ranges of the contained species, the Upper Cretaceous of the study 


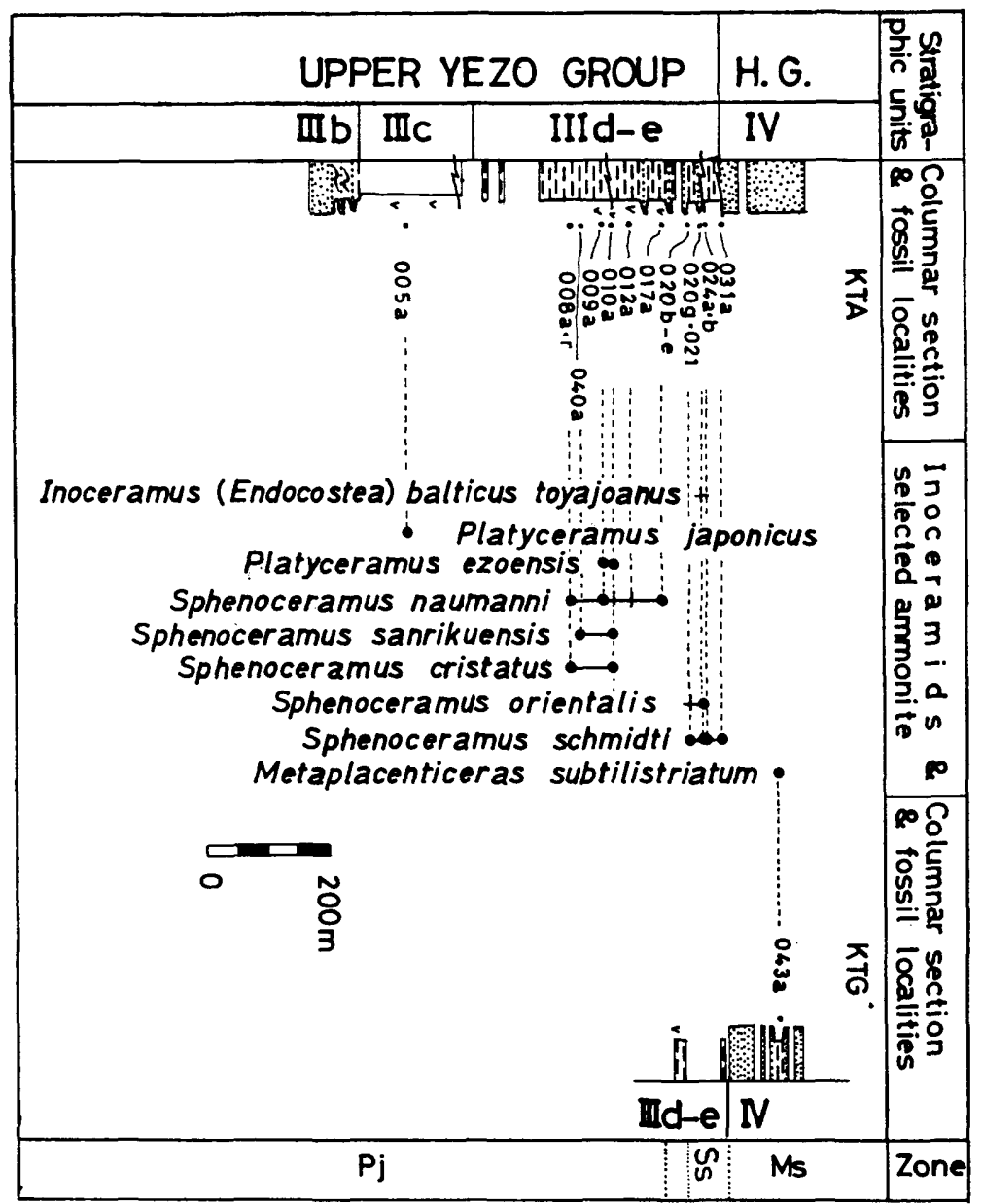

Fig. 4a. Biostratigraphic successions of the Upper Yezo Group and the Hakobuchi Group along the Tanno-sawa (left column) and Gakkono-sawa (right column) in the Saku area, Hokkaido. Legend is shown in Fig. 7. Stratigraphic units are after MATSUMOTо (1942b).

$\mathrm{Pj}$ : Platyceramus japonicus Zone, Ss: Sphenoceramus schmidti Zone, Ms: Metaplacenticeras subtilistriatum Zone.

area can be divided on the basis of inoceramid into the zones of Inoceramus uwajimensis-I. mihoensis, I. amakusensis, Platyceramus japonicus, Sphenoceramus orientalis, and S. schmidti. According to the inoceramid zonation previously presented by MATsumoto (1977) and TAKAYANAGI and MATSumoto (1981), these zones are correlated with the Coniacian, Lower Santonian, Upper Santonian and Lower Campanian, respectively. To be newly added is that the main part of the $P$. japonicus Zone is characterized by the assemblage of Sphenoceramus sanrikuensis MATSUmoto and Sugryama, S. cristatus sp. nov. and Inoceramus (Cordiceramus) kanmerai TosHIMITSU, and can be recognized as a distinct subzone. Representative species of these zones are shown in Plates 1 to 7 . 


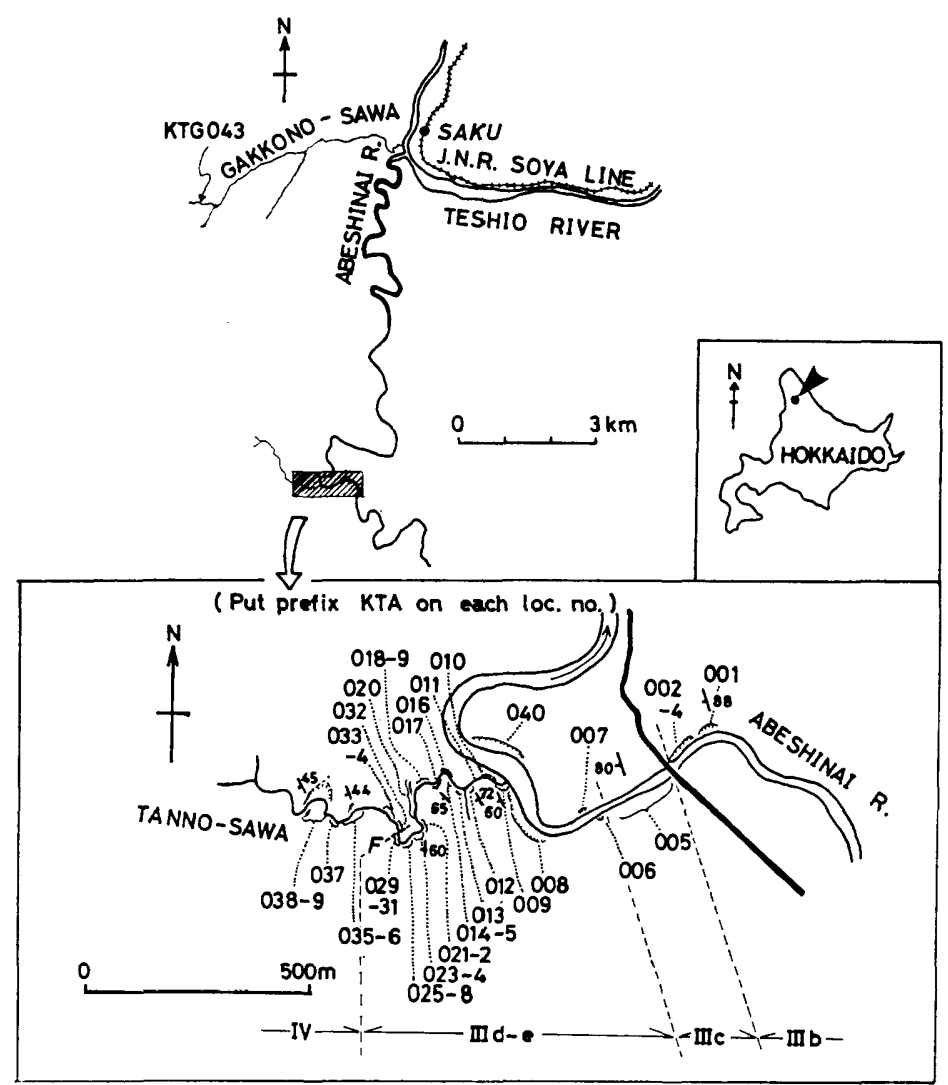

Fig. 4b. Route map in the Saku area.

\section{(1) Inoceramus uwajimensis-I. mihoensis Zone}

This zone ranges from the Lower Haborogawa Formation to the lowermost part of the Middle Haborogawa Formation. The inoceramid species obtained from the upper part of this zone are, in addition to the index species, as follows: Inoceramus aff. mihoensis MATSUMоTо, I. sp. A, I. sp. C, I. sp. D, Inoceramus (Cordiceramus) cf. cordiformis SowERBY, I. (C.) kawashitai NODA, P. yubariensis (NAGAo and MATSUmoto), Sphenoceramus naumanni (YoкоYAMA), Mytiloides aff. incertus (JIMBO).

The ammonoid species obtained from the same part are follows: Neophylloceras cf. ramosum (MEEK), Damesites cf. damesi (JIMBo), Mesopuzosia cf. pacifica MATSUMOTо, $M$. cf. yubarensis (JIMBO), Jimboiceras cf. mihoense MATSUмото, Tetragonites glabrus (Jімво), T. popetensis YABE, Gaudryceras tenuiliratum Y $\mathrm{ABE}, G$. denseplicatum (JIMBO), Anagaudryceras cf. limatum (YABE), Scaphites cf. pseudoequalis YABE, Otoscaphites sp., Clioscaphites sp., Scalarites sp., Nipponites(?) sp., Yezoceras sp., Baculites cf. princeps MATsumoto and OBata.

(2) Inoceramus amakusensis Zone

This zone ranges from the lower part of the Middle Haborogawa For- 
mation to the lower part of the Upper Haborogawa Formation. The base of this zone is defined by the first occurrence of the Inoceramus amakusensis NAGAO and Matsumoto. Inoceramus sp. A and I. (C.) cf. kawashitai occur, though rarely, in the basal part of this zone. In addition to I. amakusensis, the following inoceramids and ammonoids, occur in this zone:

Inoceramids: Inoceramus (Cordiceramus) cf. cordiformis, I. (C.) mukawaensis Nagao and Matsumoto, Platyceramus yubariensis (NAgao and Matsumoto), Sphenoceramus cf. yokoyamai (NAGAo and MATSUmoto), S. naumanni, S. nagaoi (MAtsumoto and UEDA), S. africanus (HeINZ), S. aff. cristatus, Mytiloides aff. striatoconcentricus (GÜMBEL), Inoceramus (Cordiceramus) gilberti WHITE, Ammonoids: Neophylloceras subramosum Spath, N. ramosum, Phyllopachyceras ezoense (YoкоYамA), Yokoyamaoceras kotoi (Jімво), Y. jimboi MAтsumoto, Damesites damesi, D. semicostatus MATsumoto, D. sugata (ForBes), Hauericeras (Gardeniceras) angustum (YABE), Kitchinites (Neopuzosia) ishikawai (JIMBO), $K$. (N.) haboroensis Matsumoto and INoma, $K$. (N.) cf. japonicus Spath, Eupachydiscus haradai (ЈIMBO), Anapachydiscus deccanensis yezoensis MATSUмото, A. sutneri (Yokоуама), Menuites pusillus Matsumoto, M. japonicus Matsumoto, Tetragonites glabrus, T. popetensis, T. cf. epigonus (Kossmat), Zelandites kawanoi (JIMBo), Gaudryceras tenuiliratum, G. denseplicatum, G. intermedium, Anagaudryceras yokoyamai (YABE), Polyptychoceras obstrictum (JIMBo), P. haradanum (YокоҮАма), P. subquadratum (YокоYАMA), P. pseudogaultinum (YoKочама), P. subundulatum (YoKoYама), P. yubarense, Neocrioceras spingerum (JIмBO), Eubostrychoceras densicostatus MATSUмото, Hyphantoceras cf. oshimai (YABE), H. orientale (YABE), Baculites bailyi WooDs, B. uedae Matsumoto and OBATA, B. boulei Collignon, B. capensis Woods, B. princeps, Pseudoxybeloceras quadrinodosum (JiмBo), Glyptoxoceras(?) sp., Sornayceras omorii MATsumoto, S. proteus Matsumoto, Protexanites (Anatexanites) fukazawai (YABE and SHIMIZU), $P$. (A.) aff. fukazawai, $P$. (Miotexanites) minimus MATSUмото, Paratexanites compressus MATsumoto, $P$. aff. orientalis (YABE), Texanites cf. collignoni KLINGER and KENNEDY, T. cf. quinquenodosus (REDTENBACHER), Plesiotexanites kawasakii (KAWADA), P. pacificus (MATSUmoto), cf. $P$. shiloensis Young, P. (Eutexanites) sp., Haboroceras haboroense gen. et sp. nov., $H$. aff. haboroense.

\section{Explanation of Plate 23}

Fig. 1. Inoceramus uwajimensis (YeHARA)

GK. H8230 from loc. RH2435b1, in the Machiyoi-zawa. Left valve. $\times 1$.

Fig. 2. Inoceramus (Cordiceramus) kawashitai NoDA

GK. H8231 from loc. RH2439, in the Machiyoi-zawa. Right valve. $\times 1$.

Fig. 3. Inoceramus mihoensis Matsumoto

GK. H8234 from loc. RH2134a4, in the Nakanofutamata-gawa. Left valve. $\times 1$.

Fig. 4. Platyceramus yubariensis Nagao and Matsumoto

GK. H8233 from loc. RH2153a2, in the Nakanofutamata-gawa. Left valve. $\times 1$

Fig. 5. Inoceramus amakusensis NAGAO and MATSUMoto

GK. H8232 from loc. RH2506a, in the Nakanofutamata-gawa, collected by K. Muramoto, S. Uchida, S. Yamaguchi and S. T. Left valve. $\times 0.4$. 

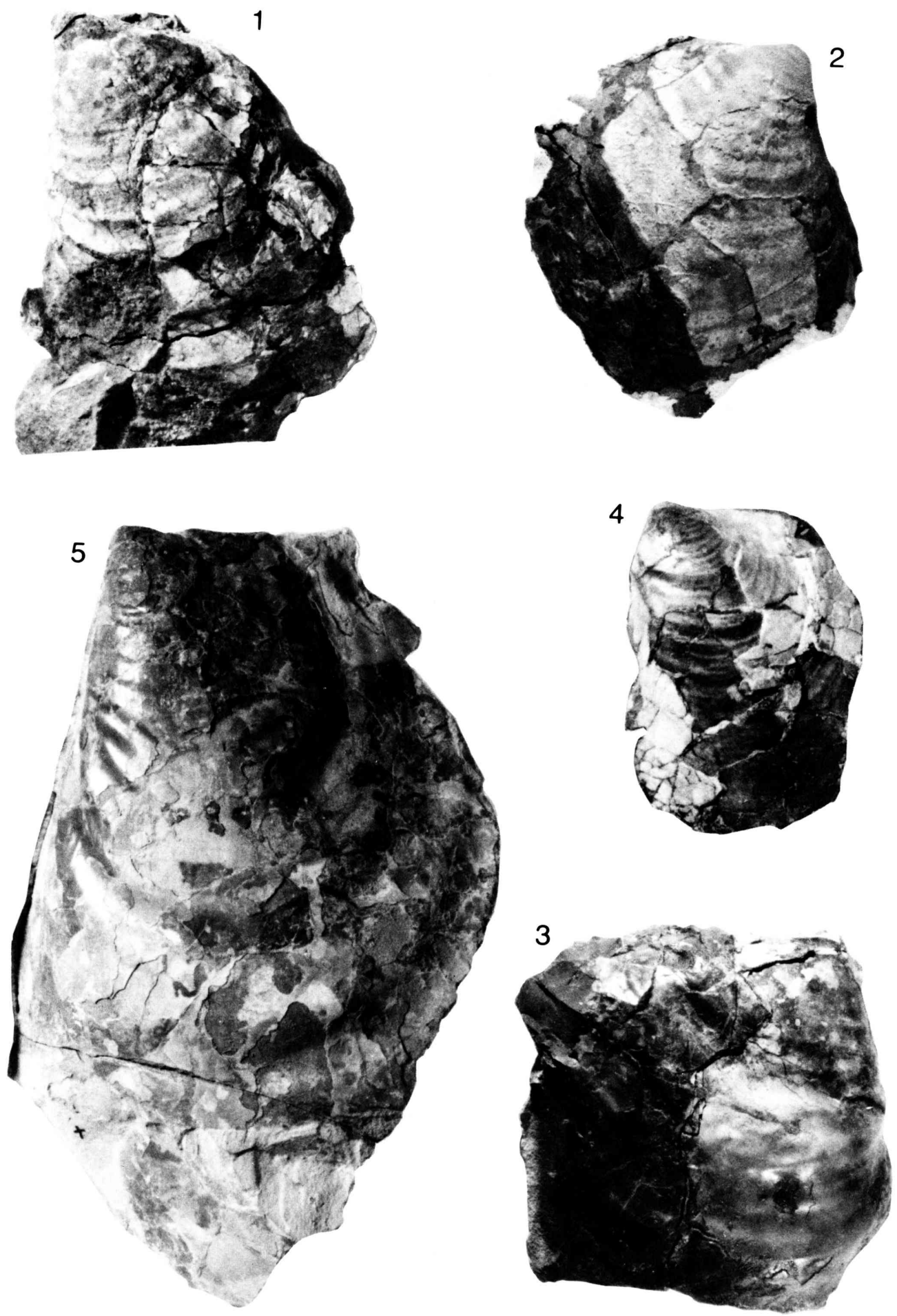

S. Toshimitsu: Biostratigraphy of the Santonian 

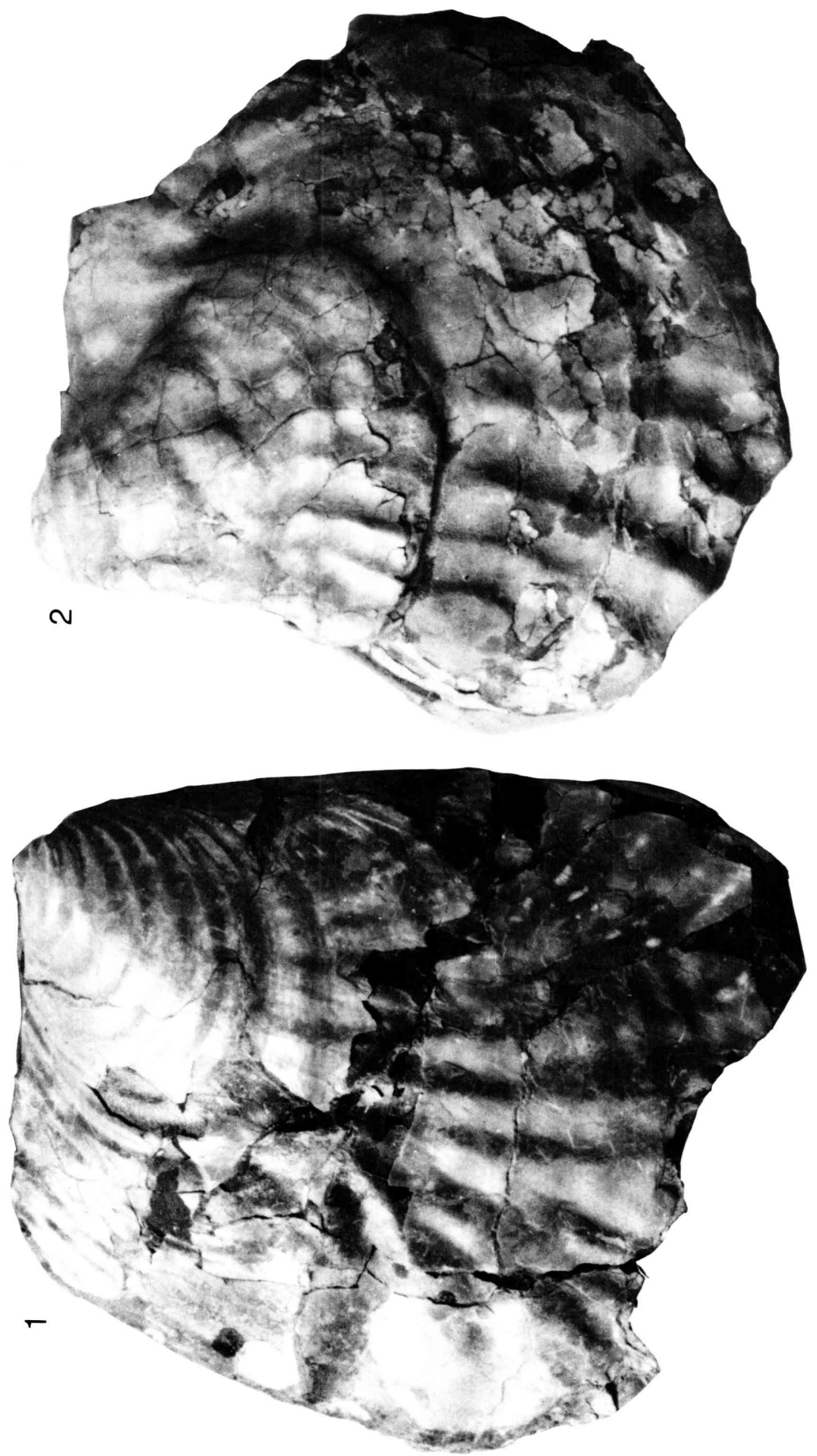

S. Toshimitsu: Biostratigraphy of the Santonian 


\section{(3) Platyceramus japonicus Zone}

This zone comprises the strata above the base of the middle part of the Upper Haborogawa Formation. This zone is subdivided into the following two parts.

(A) Lowermost part; The lowermost part is represented by mudstone of several ten meters in thickness above the UHs1 sandstone. The base of this subzone is drawn at the level of the first occurrence of Platyceramus japonicus (NAGao and Matsumoto). In addition to the zonal index species, this subzone contains the following inoceramid and ammonoid species:

Inoceramids: 1 . (Endocostea) balticus balticus BöHM, I. (Endocostea) balticus toyajoanus NAGao and MATsumoto, Platyceramus ezoensis (YoKoYama), P. cf. cycloides (WEGNER), Sphenoceramus cf. yokoyamai, S. naumanni, S. nagaoi, Ammonoids: Neophylloceras subramosum, Damesites damesi, Hauericeras cf. angustum, Eupachydiscus haradai, cf. Anapachydiscus deccanensis yezoensis, $A$. (Neopachydiscus) cf. naumanni (YoKoYAмA), Menuites pusillus, M. cf. japonicus, Gaudryceras tenuiliratum, G. denseplicatum, G. intermedium, Polyptychoceras haradanum, P. cf. yubarense, Baculites capensis, Neocrioceras spingerum, Submortoniceras cf. condamyi (CoLLIGNON).

(B) Main part; The upper main part of the Upper Haborogawa Formation is designated as the subzone of Sphenoceramus sanrikuensis-S. cristatusInoceramus (Cordiceramus) kanmerai. This subzone is recognized by the occurrence of at least one of the three index species. It contains, besides the index species, the following species:

Inoceramids: Inoceramus (Cordiceramus) cf. cordiformis, Inoceramus (Endocostea) balticus balticus, I. (E.) balticus toyajoanus, Platyceramus japonicus, $P$. ezoensis, Sphenoceramus naumanni, S. haboroensis sp. nov., S. cf. kiritachiensis sp. nov.,

Ammonoids: Neophylloceras subramosum, N. ramosum, Phyllopachyceras ezoense, Damesites damesi, D. sugata, Hauericeras angustum, Kitchinites (Neopuzosia) ishikawai, K. (N.) haboroensis, K. (N.) japonicus, Anapachydiscus aff. fascicostatus (YABE), Eupachydiscus haradai, E. teshioensis (JIMBO), Menuites pusillus, M. japonicus, Tetragonites glabrus, T. popetensis, T. epigonus, Gaudryceras tenuiliratum, G. denseplicatum, G. intermedium, G. striatum (JIмво), Polyptychoceras haradanum, $P$. cf. subquadratum, $P$. cf. pseudogaultinum, $P$. subundulatum, P. yubarense, Neocrioceras (?) sanushibensis WRIGHT and MATSUMOTO, Hyphantoceras orientale, Baculites bailyi, B. capensis, B. princeps, Protexanites $(P$.) bontanti shimizui Matsumoto, P. (Anatexanites) cf. fukazawai, Plesiotexanites kawasakii, P. pacificus, P. (Eutexanites(?)) sp., Haboroceras haboroense, Submortoniceras cf. condamyi.

\section{Explanation of Plate 24}

Fig. 1. Platyceramus japonicus (NAGAo and Matsumoto)

GK. H8235 from loc. RH2530a, in the Nakanofutamata-gawa. Right valve. $\times 1$.

Fig. 2. Inoceramus (Cordiceramus) kanmerai Toshimitsu

GK. H8111, holotype, from loc. $\mathrm{RH} 4023 \mathrm{c1}$, in the Otodo-zawa. Left valve. $\times 1$. 
In addition, Menabites mazenoti Collignon reported by MATSUMoto and TAKahashi (1986) is probably assigned to this zone. OKADA and Matsumoto (1969, p. 316) listed Inoceramus (Cordiceramus) n. sp. aff. I. mukawaensis from loc. R421 ( $=$ RH1211) in the middle part of the Upper Haborogawa Formation along the Sakasa-gawa. It is identified with $I$. (C.) kanmerai.

\section{(4) Sphenoceramus orientalis Zone}

This zone is represented by the uppermost part of the Upper Haborogawa Formation. It is differentiated by the occurrence of $S$. orientalis (SokoLOw) from the subjacent zone. It contains, besides the zonal index species, Sphenoceramus naumanni, S. cf. nagaoi, S. cristatus, rarely $S$. cf. sanrikuensis, Hauericeras angustum and Polyptychoceras sp.

(5) Sphenoceramus schmidti Zone

This is a superjacent zone represented by the occurrence of $S$. schmidti, S. naumanni, S. cf. nagaoi, S. kiritachiensis, Polyptychoceras haradanum and Kitchinites (Neopuzosia) sp.

The above explained zones abound in long ranging ammonoid species. Some species of the Texanitinae, however, have a short range (Fig. 27f). On the basis of these species, the Middle and Upper Haborogawa Formations can be divided into two zones: Texanites collignoni-T. quinquenodosus Zone below and Plesiotexanites kawasakii-P. pacificus Zone above. The boundary of these two zones is defined by the first occurrence of the latter species, and is placed at the Middle part of the Middle Haborogawa Formation. Moreover, the succession from the lowest part of the Upper Haborogawa Formation to the middle part of this formation can be designated as the total range zone of Protexanites fukazawai-Protexanites bontanti shimizui. These species are reported by Matsumoto (1970, p. 146, pl. 23, fig. 4) from loc. 82206 (near loc. RH4074) in the Otodo-zawa and by Matsumoto and Hirano (1976, p. 335, pl. 35, fig. 2) from near loc. CK80 of UEDA et al. (1963) (= RH7021-7022) in the Detofutamatagawa. Their stratigraphic positions are, together with others, shown in Fig. $27 f$. Texanites cf. amakusensis, Submortoniceras cf. condamyi and Menabites mazenoti reported by MATSUMOTO and TAKAHASHI (1986) are important for correlation, although they were rarely found. Texanites cf. amakusensis and Menabites mazenoti are based on the specimens from two different floated calcareous

\section{Explanation of Plate 25}

Fig. 1. Texanites sp. cf. T. collignoni KLINGER and KENNEDY GK. H8240 from loc. RH1271b in the Sakasa-gawa. $\times 1$.

Fig. 2. Texamites sp. cf. T. quinquenodosus (REDTENBACHER) GK. H8241 from loc. RH1267a in the Sakasa-gawa. $\times 1$.

Fig. 3. Texanites sp. cf. T. amakusensis (YABE) GK. H8244 from loc. RH2802p1 in the Shimizu-zawa, collected by T. MATSUмото, M. NodA and S. T. Lateral views $(\mathrm{a}, \mathrm{b})$; ventral (c); cross-section (d). $\times 1$. 

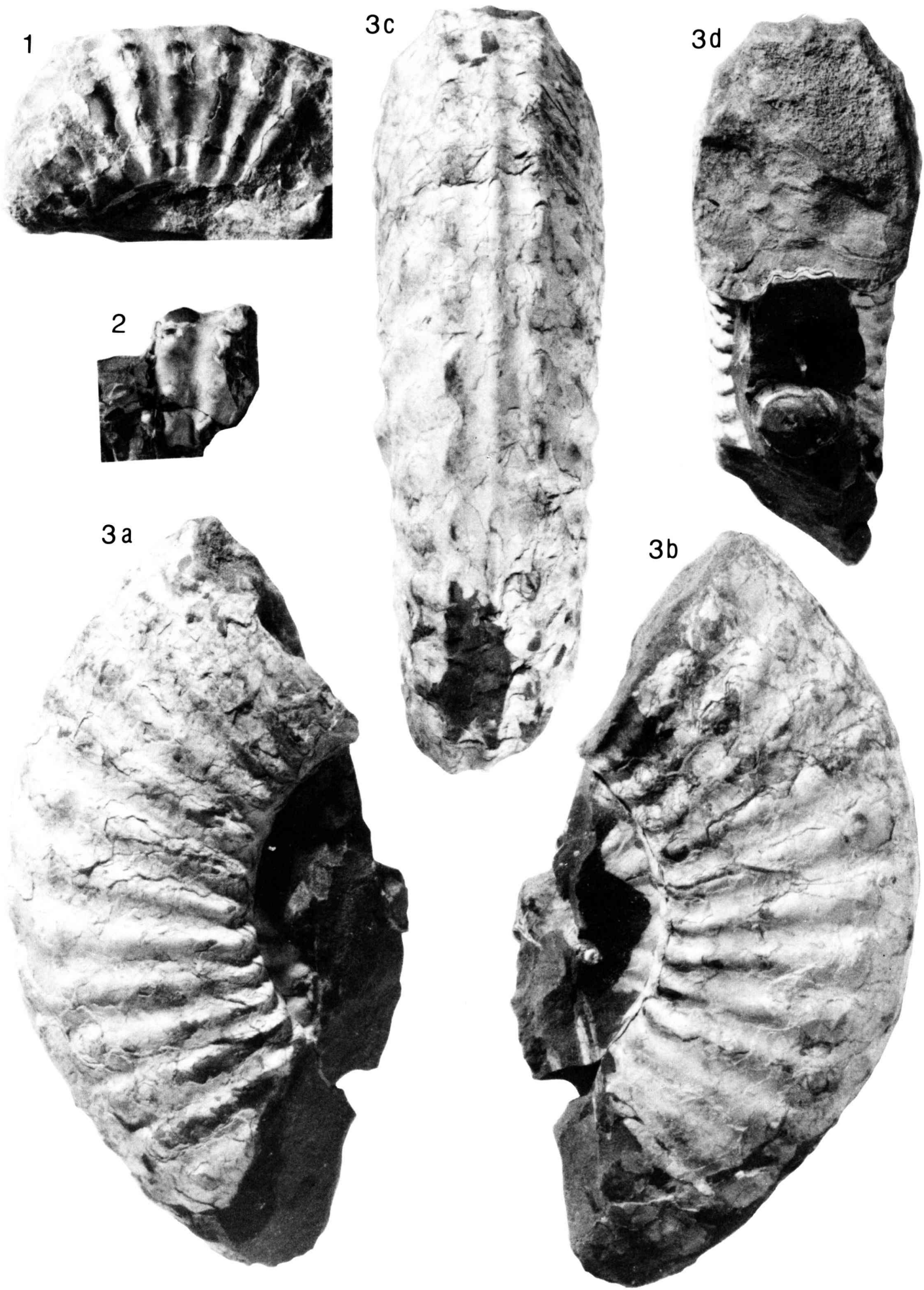

S. Toshimitsu: Biostratigraphy of the Santonian 

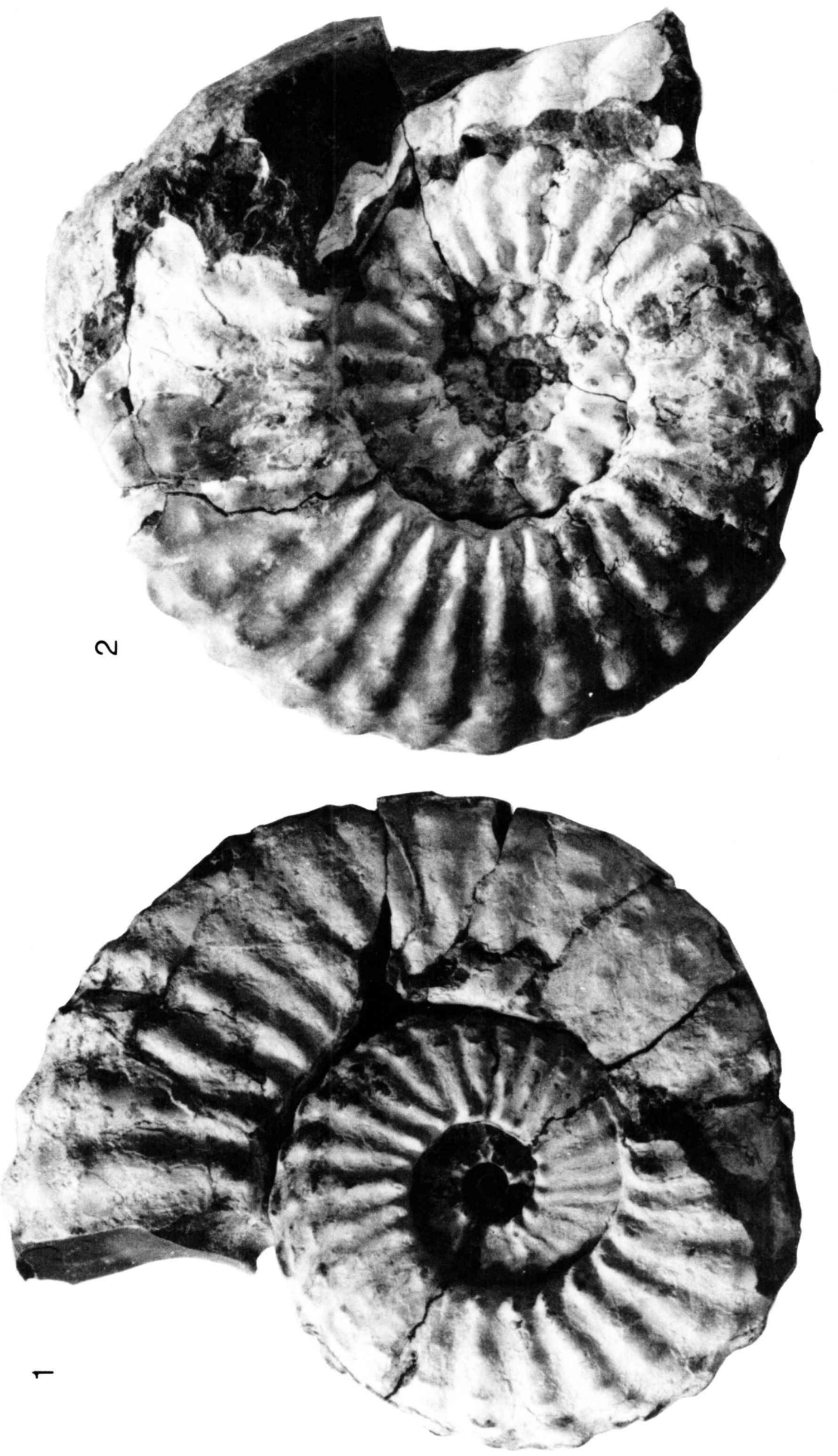

S. Toshimitsu: Biostratigraphy of the Santonian 
nodules, but the stratigraphic position of the former is inferred to be restricted to the upper part of the Middle Haborogawa Formation and that of the latter to the upper part of the Upper Haborogawa Formation from the surrounding geological conditions.

The stratigraphic distribution of inoceramids and selected ammonoids in the area southerly adjacent to Haboro, such as the Kotanbetsu and Obira areas, and the northerly neighbouring Saku area are shown in Figs. 14a, b, $15 \mathrm{a}, \mathrm{b}$ and $4 \mathrm{a}$. Their stratigraphic positions in these areas are quite similar to those of the Haboro area. The ranges of Sphenoceramus sanrikuensis, $S$. cristatus, S. haboroensis, S. kiritachiensis and S. aff. lingua GoLDFuss are clearly retained within the $S$. orientalis Zone. In the Saku area, Metaplacenticeras subtilistriatum (JIMBO) occurs from a sandy siltstone bed at loc. KTG043a (near loc. T1194 of MATSUMOTO and OKADA, 1973, fig. 3) of the middle part of the Hakobuchi Group. Its stratigraphic position is above the Sphenoceramus schmidti Zone. The same relationships has been confirmed by Matsumoto and MiYauchi (1984, p. 35) in the Upper Cretaceous of the Soya area, northern Hokkaido.

\section{Interregional Correlation}

Only a few species of ammonoids which are useful for the interregional correlation are known from the Inoceramus uwajimensis-I. mihoensis Zone in the studied sections. They are Barroisiceras onilahyense BASSE obtained from the Obira area (TANABE et al., 1977; MATsumoto et al., 1981) and Forresteria aff. itwebae vaN HoEPEN from the Haboro area (TOSHIMITSU, 1985). The stratigraphic positions of these species are assigned to the middle Coniacian. TosHIMITSU and MAIYA (1986) obtained two species of planktonic Foraminifera, Whiteinella archaeocretacea PESSAGNo and Dicarinella imbricata (MORNOD), from the basal part of the Middle Haborogawa Formation (H-30, loc. RH2146) in the Haboro area. ROBASZYNSKI et al. (1984) and CARON (1985) have allocated the last occurrences of these two species at the latest Coniacian, which conforms with the age indicated by inoceramid species, although they are not associated with each other. Therefore the Inoceramus uwajimensis-I. mihoensis Zone is certainly correlated with the Coniacian.

The base of the Inoceramus amakusensis Zone is defined by the first appearance of the zonal index, but this species is endemic. Fortunately, however, in the lower part of this zone occur Texanites cf. collignoni and T. cf. quinquenodosus which are common and worldwide in the Lower Santonian. The latter

\section{Explanation of Plate 26}

Fig. 1. Plesiotexanites pacificus (MATSUMOTO) GK. H8242 from loc. RH5144a in the Chimei-zawa. $\times 1$.

Fig. 2. Plesiotexanites kawasakii (KAWADA)

GK. H8243 from loc. RH1214b in the Sakasa-gawa, collected by S. UcHIDA and S. T. $\times 1$. 
species is exceptionally recorded also from the upper part of the Santonian in Madagascar (CollignoN, 1966). It is uncertain whether the first appearances of $I$. amakusensis and T. collignoni or T. quinquenodosus are coincident in northwestern Hokkaido, because of the sporadic occurrence of the texanitine ammonites. The co-occurrence of $I$. amakusensis and $T$. collignoni, which had been identified as $T$. oliveti (BLANCKENHORN), is recorded from the Himenoura Group in the western part of Hinoshima, Amakusa area, Southwest Japan (MATsumoto and UEDA, 1962). Anyway, the levels of the first occurrence of these two species are very close. Paratexanites aff. orientalis, Sornayceras omorii and S. proteus obtained from the lower part of the Middle Haborogawa Formation belong to this zone. S. omorii and S. proteus which are common in the $I$. mihoensis Zone (Upper Coniacian) of the Ikushumbetsu area of central Hokkaido (MAтsumoto, 1970) range up to the lower part of the Santonian.

The Plesiotexanites kawasakii-P. pacificus Zone follows the above mentioned Texanites collignoni-T. quinquenodosus Zone. P. kawasakii and $P$. pacificus are relatively common in the middle part of the Inoceramus amakusensis Zone to Platyceramus japonicus Zone in the Japanese province, but are unknown from other provinces of the world, except for $P$. cf. kawasakii reported from California (MAтsUмото, 1959, p. 124). Only a single specimen of Texanites cf. amakusensis was found from the probably lower part of the $P$. kawasakii-P. pacificus Zone. Three specimens of Protexanites (Anatexanites) fukazawai were obtained from the middle and upper parts of the $P$. kawasakii- $P$. pacificus Zone in the Haboro and Kotanbetsu areas, forming a subzone. Although the stratigraphic position of Texanites amakusensis has not been precisely known in Amakusa, Kyushu, the type locality of this species (YABE, 1902), KASE et al. (1984) obtained this species from somewhat below the horizon of Protexanites (Anatexanites) fukazawai in the Kuji area of Northeast Japan. It is noted that this stratigraphic relationship is the same as that of the Haboro area. It is thus suggested that $T$. amakusensis may form the subzone in the lowest part of the P. kawasakii$P$. pacificus Zone, slightly below the $P$. fukazawai Subzone. Three specimens of Protexanites (Protexanites) bontanti shimizui are obtained and other two specimens of the same species are reported by Matsumoto (1970) and Matsumoto and HIRANo (1976). Their stratigraphic positions are situated in the middle part of the $P$. kawasakii-P. pacificus Zone. The subzone of this species largely overlaps the $P$. fukazawai Subzone, but the former is generally younger than the latter. Therefore both subzones are better to be united and regarded as a total range zone of $P$. fukazawai and $P$. bontanti shimizui, as mentioned above. Another subzone suggested at present by only two small specimens of $S u b$ mortoniceras condamyi can be placed in the upper part of the $P$. kawasakii$P$. pacificus Zone, beginning somewhat later than the $P$. $(P$.) bontanti shimizui Subzone.

The Platyceramus japonicus Zone probably starts at the same level as the Submortoniceras cf. condamyi Subzone, although they have not been found at one and the same locality. Recently, Matsumoto and TAshiro (1982) and Matsumoto et al. (in press) pointed out that Platyceramus japonicus zone, which has been correlated with the Upper Santonian, contains the Campanian 


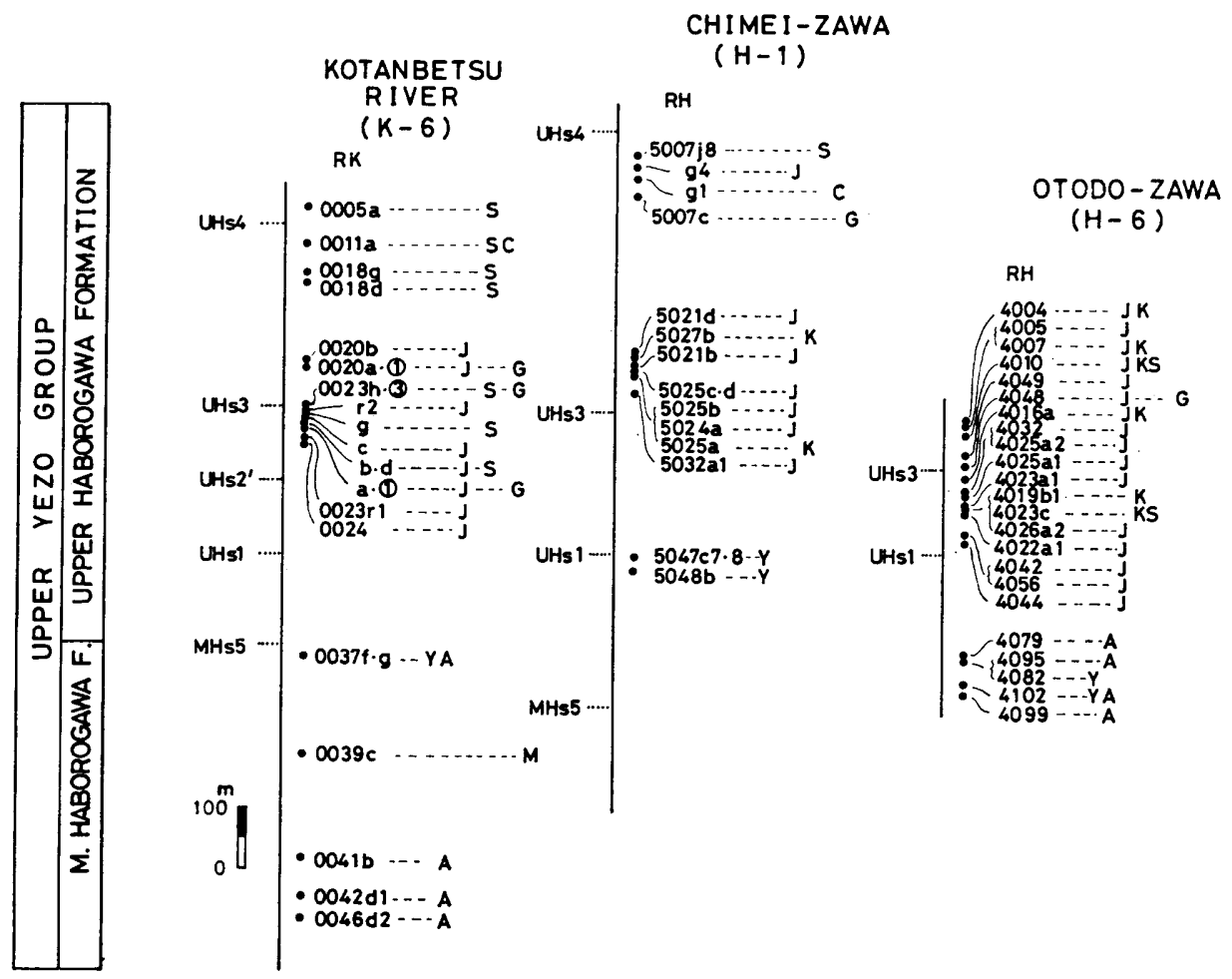

Fig. 5. Stratigraphic relationships between the selected mega- and micro-fossils, along the Otodo-zawa, Chimei-zawa and Kotanbetsu River.

$\mathrm{Y}$ : Platyceramus yubariensis, A: Inoceramus amakusensis, J: Platyceramus japonicus, K: Inoceramus (Cordiceramus) kanmerai, S: Sphenoceramus sanrikuensis, C: Sphenoceramus cristatus, G: Globtruncana arca, M: Marginotruncana pseudolinneiana.

microfossils in the Monobe area, Southwest Japan and Ikushunbetsu area, central Hokkaido, respectively. The investigation of Foraminifera is being carried on in northwestern Hokkaido, and Dr. S. MAIYA has kindly helped me in the identification of foraminiferal species on the samples which I collected. According to him (letter of December 23th, 1986), Globotruncana arca (CUSHMAN) occurs from loc. RH4048 in the Otodo-zawa, RH5007c in the Chimei-zawa, RK0020 (1), 0023 (1) and 0023 (3) in the Kotanbetsu River (Fig. 5). All of these localities belong to the Platyceramus japonicus Zone. The first appearance of Globotruncana arca corresponds with the base of the Campanian in Japan (MAIYA and TAKAYANAGI, 1977; MAIYA, 1985) and California (Douglas, 1969), West Carpathians (SAlaj and GašParikovA, 1983), Poland (PozARYska and PerYt, 1979) and Tunisia (SAlAJ, 1984). On the other hand, Marginotruncana pseudolinneiana PESSAGNO occurs at loc. RK0039c in the Kotanbetsu River. It ranges from the middle part of the Turonian to the latest Santonian (CARON, 1985). Therefore the boundary between the Santonian and Campanian in the sense of the foraminiferal biostratigraphy is drawn between the horizons of RK0023 (1) and RK0039c. 
KLINGER and KENNEDY (1980) regard the range of $S$. condamyi as the Upper Santonian to the Lower Campanian in Zululand and Pondoland, South Africa, but the clear evidence indicating the Upper Santonian has not been found, as far as the stratigraphical descriptions by KENNEDY and KLINGER (1975) and KLINGER and KENNEDY $(1980,1981)$ are concerned. BiRkelund et al. (1984) have proposed a possibility that the evolution of Submortoniceras from Texanites is a good marker of the base of the Campanian. If this proposal is accepted, the occurrence of Submortoniceras cf. condamyi certainly indicates the Campanian.

As I mentioned above, the first appearances of Platyceramus japonicus, Submortoniceras cf. condamyi and Globotruncana arca are nearly contemporaneous. Therefore, the occurrence of $P$. japonicus really indicates the Lowest Campanian, although generally it has been thought as the zonal index of the Upper Santonian. The horizon of Menabites mazenoti reported by MATsumoto and TAKAHASHI (1986) is probably assigned to the upper part of the $P$. japonicus Zone. They have inferred that $M$. mazenoti as well as $M$. menabensis CoLlignon ranges from the Lower to the Middle Campanian.

The Sphenoceramus sanrikuensis-S. cristatus-I. (C.) kanmerai Subzone occupies the main part of the $P$. japonicus Zone, and persists to the $S$. orientalis Zone. The three species are the indices of the Lowest Campanian. The species diversity of Sphenoceramus in this subzone is high. A similar feature is known in the Upper Santonian to the Lower Campanian of Europe (SEITZ, 1965) and also in the Upper Santonian of USSR Far East (PeRgament, 1974, 1978). In other words, the diversity of Sphenoceramus occurred in parallel in Europe and Japan or the northwestern Pacific province.

The specimens of $S$. sanrikuensis described by Matsumoto and SugrYama (1985) have been obtained from the upper part of the Okonai Member of the Taneichi Formation in northern Honshu. That member is probably correlated with the Kunitan Formation of the Kuji Group in the northern Honshu. From the Kunitan Formation the lectotype and other specimens of Platyceramus japonicus were obtained long ago (SASA, 1932) and some species of Texanites and Plesiotexanites have been recently found (KAWAKAMI et al., 1983). Unfortunately the precise stratigraphic relationships among these species are uncertain in the Kuji area.

Sphenoceramus orientalis is the index of the Lowest Campanian and is stratigraphically distributed below the first occurrence of S. schmidti in Japan and British Columbia (WARD, 1978). The former species, however, persists into the "Lower Campanian" (=S. schmidti Zone) in the Tomiuchi and Saku areas of central and northern Hokkaido (MAтSUмото, 1943), and then the co-occurrence of both species was confirmed in the Saku area in this study (loc. KTA020g; Pl. 5, Figs. 1, 2, 3). The Sphenoceramus orientalis Zone and S. schmidti Zone has been regarded as the Lower Campanian in Japan and California (MATsumoto, 1960) and British Columbia (WARD, 1978). However, it was confirmed to be the upper Lower Campanian because of the existence of the underlying Lowest Campanian Platyceramus japonicus Zone.

On the basis of the above mentioned correlation, the ranges of the selected 


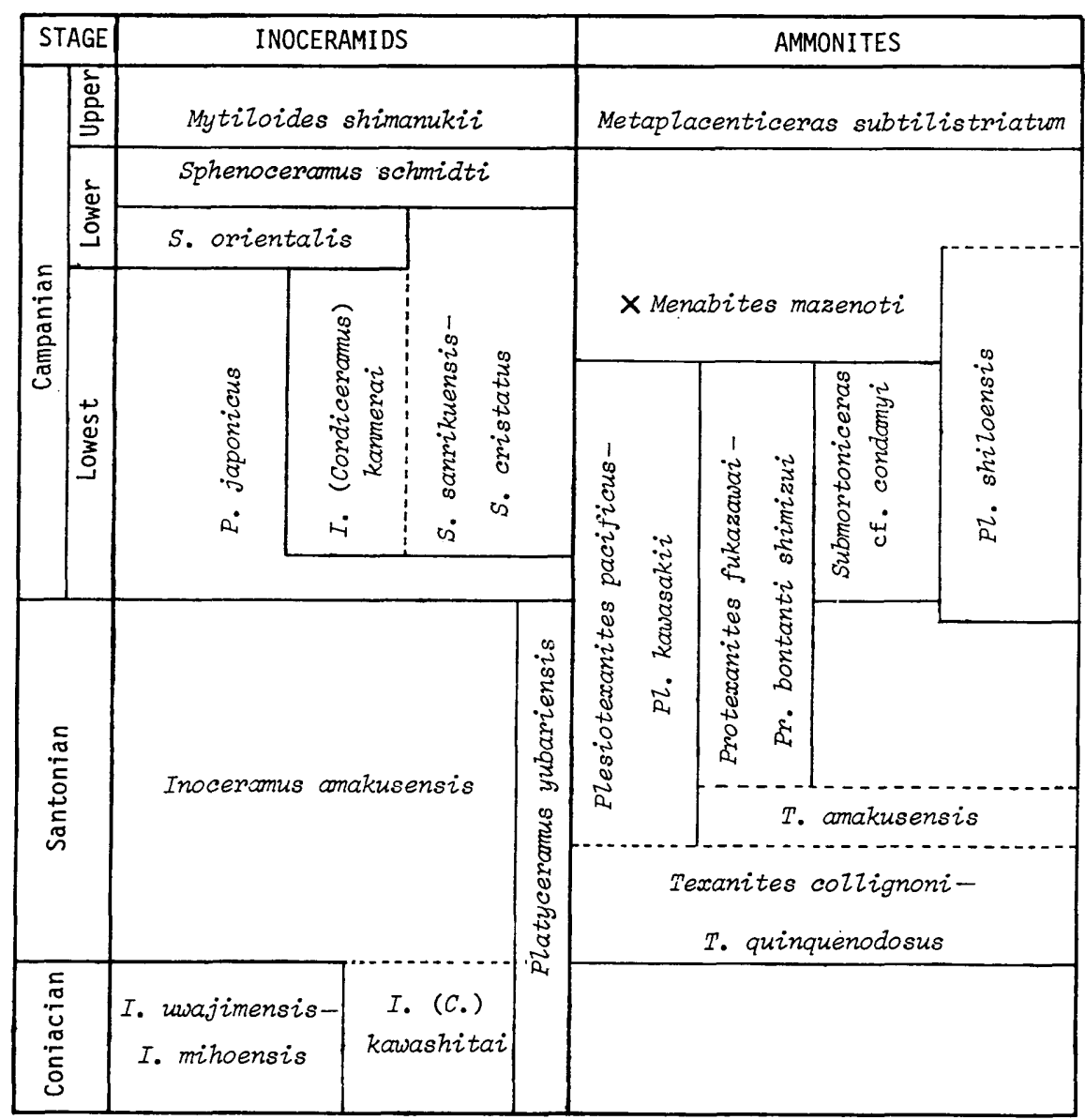

Fig. 6. Revised zonal scheme for the Santonian and Lower Campanian of Japan.

species in northwestern Hokkaido are shown in a summarized chart of Fig. 6 .

\section{Discussion}

KENNEDY $(1983,1984 a)$ restudied the ammonites faunas of the stratotype of the Upper Cretaceous in the Aquitaine basin, France, and clarified that DE Grossouvre's (1901) zonation, i.e. Texanites texanus (ROEMER) below and Placenticeras syrtale (MORTON) above, are not realized there, because the two index ammonite species do not occur in the type area. Then he thought that the base of the Santonian Stage can be taken at the appearance of Placenticeras polyopsis (DUJARDIN) and Texanites (Texanites) species, and that the stage may correspond to the Total Range Zone of $P$. polyopsis, although the occurrence of ammonites is too rare to allow the erection of a usable zonation. The basal Campanian yields Placenticeras bidorsatum (ROEMER), but its occurrence is also very rare.

The Santonian of the other regions of Europe and Russian Platform show 
similar stratigraphic succession. In the former the base of the Santonian Stage is defined by the appearance of Platyceramus undulatoplicatus (ROEMER) and 'Texanites texanus' (ERNst et al., 1979; Schulz et al., 1984). In the Europian Boreal realm, the Santonian Stage is divided into tripartite zones by means of macrofossils, i.e. Lower, Middle and Upper, and each of them is subdivided into bipartite zones. However belemnites are predominant in this realm, and only the Platyceramus undulatoplicatus Zone of the Lowest Santonian or two zones including $P$. undulatoplicatus Zone and the Inoceramus (Cordicaramus) cordiformis Zone of the lower Middle Santonian are recognized. Therefore the Santonian and Campanian Stages are characterized by belemnites except for the Lower Santonian Platyceramus undulatoplicatus and Inoceramus (Cordiceramus) cordiformis Zones (NAIDIN, 1979; ERNST et al., 1979; Schultz et al., 1985; SEITZ, 1961, 1965, 1967; TRÖGER, 1966). No successive ammonite zones are established for the Santonian Stage of Europe and only the zone of "Texanites texanus" of the lowest part of the Santonian is presented (ERNST et al., 1979).

In the Mediterranean area, for example, Tunisia, the basal Santonian is represented by Platyceramus siccensis (PERVINQUIÈRE) and 'Texanites oliveti' (SALAJ, 1984), but the Upper Santonian zonation has not been well established on macrofossils.

According to Collignon (1948a, b) and Basairie and Collignon (1972), the Santonian Stage of Madagascar is divided into the following three zones by means of mainly texanitine ammonites (see MATSUMoTo and HARAGUCHI, 1978). (1) Lower Santonian: zone of Texanites oliveti (BLANCKENHORN) ( $=T$. collignoni) with $T$. texanus gallicus Collignon, $T$. texanus hispanicus ColligNon and $T$. cf. roemeri (LASSWITZ).

(2) Middle Santonian: zone of Texanites hourcqui CoLlignon with T. hourcqui var. souromarayensis CoLligNoN, T. oliveti var. spinosa CoLligNoN, T. texanus gallicus, T. rarecostatus CollignoN, T. quadrangulatus ColligNoN, T. soutoni (BAILY), T. aff. quinquenodosus (REDTENBACHER), T. venustus Collignon, $T$. [= Plesiotexanites $]$ stangeri (BAILEY) including var. densicostus (SPATH) and var. sparsicostus (SPATH).

(3) Upper Santonian: zone of Pseudoschloenbachia umbulazi (BAILY) with $T$. dichotomus Collignon, T. mikobokensis Collignon, T. ralijaonai Collignon, T. quadrangulatus, T. texanus gallicus, T. texanus hispanicus, T. hourcqui var. souromarayensis, T. pseudotexanus, T. quinquenodosus and T. [=Plesiotexanites] stangeri var. densicostus.

(4) Lower Campanian: zone of Anapachydiscus wittekindi SCHLUTER and Eulophoceras jacobi HOURCQ.

In the Western Interior province, U.S.A., CoBBAN (in OBRADOvich and CoBBAN, 1975) established six zones for the Santonian Stage by means of the following zonal indices: in ascending order, (1) Scaphites depressus REESIDE and Inoceramus undulatoplicatus, (2) Clioscaphites saxitonianus (MCLEARN), (3) Clioscaphites vermiformis (MEEK and HAYDEN), (4) Clioscaphites choteauensis CoBBAN, (5) Desmoscaphites erdmanni CoBBAN and (6) Desmoscaphites bassleri REESIDE. In the southern Interior Plains of Canada, a similar zonation is established by CALDWELL and NORTH (1984). In Texas, Young (1963) shows 
a schem of zonation for the Santonian of Texas and also a range chart of selected species, as follows :

Lower Santonian

(1) zone of Texanites stangeri densicostus

(associated with Inoceramus undulatoplicatus)

(2) zone of Texanites texanus texanus

(associated with Inoceramus undulatoplicatus)

(3) zone of Texanites texanus gallicus

Upper Santonian

(4) zone of Texanites shiloensis

Lower Campanian

(5) zone of Submortoniceras tequesquitensis Young.

In Siberia, the Lower Santonian is indicated by Inoceramus cardissoides GoldFuss, and the Upper Santonian by I. patootensis DE LORIOL and the Lower Campanian by Scaphites hippocrepsis (DEKAY) (PERGAMENT, 1978). In the USSR Far East, i.e. Sakhalin and Kamchatka-Koryak regions, the Inoceramus undulatoplicatus Zone for the lower Santonian, the Inoceramus transipacificus Zone for the middle Santonian and the Inoceramus patootensis Zone for the upper Santonian to the lower Campanian are recognized (PERGAMENT, 1978).

In Japan, Matsumoto (1977) and TAKaYANagi and Matsumoto (1981) have shown two zones for the Santonian by means of inoceramids, that is, the Inoceramus amakusensis Zone below and the Platyceramus japonicus Zone above, and two zones for the Lower Campanian, the Sphenoceramus orientalis Zone below and S. schmidti Zone above. Furthermore, Matsumoto (in Matsumoto and HARAGUCHI, 1978) has shown three zones for the Santonian by the texanitine ammonites, i.e. Texanites olivetti (lower), Plesiotexanites kawasakii, P. pacificus and Protexanites fukazawai (middle), and Plesiotexanites shiloensis (upper). However, this zonation was modified in this study as mentioned above. As shown in Fig. 6, the base of the Japanese Santonian is definited by the appearance of Inoceramus amakusensis and Texanites collignoni or T. quinquenodosus, and the base of the Campanian is shown by the appearance of the Platyceramus japonicus together with Submortoniceras cf. condamyi and Globotruncana arca.

Therefore the Santonian Stage in Japan consists of only one inoceramid zone, the Inoceramus amakusensis Zone, and two ammonoid zones, i.e. the Texanites collignoni-T. quinquenodosus Zone and the Plesiotexanites kawasakii-P. pacificus Zone which extends to the Lower Campanian. Moreover the zone of $P$. kawasakii $-P$. pacificus may be subdivided into two subzones: the subzone of Texanites amakusensis (below) and the subzone of Protexanites (P.) bontanti shimizui$P$. (A.) fukazawai (above). Although the stratigraphic positions of $P$. bontanti shimizui from the Haboro area described by Matsumoto (1970, p. 237, pl. 31, figs. 1, 2) were unknown, the horizon of the specimen (GK. H5631) of the species came from the Chikubetsu coal mine is inferred to be in the middle part of the Upper Haborogawa Formation, which agrees with the stratigraphic distribution established in this paper. The exact horizon of the holotype of $P$. bontanti shimizui in Sakhalin cannot be reexamined, but it belongs to the zone of Plesiotexanites kawasakii (MAтsumoto, 1970, p. 239). This is in accord 
with the above-mentioned zonal scheme in which the range of $P$. bontanti shimizui is known to be from the uppermost Santonian to the lowermost Campanian. KENNEDY (1984b, p. 112-114) referred the incorrectly inferred horizon of $P$. bontanti shimizui (Lower Santonian; MAtsumoto, 1970; MatsuMOTO and HARAGUCHI, 1978), and he suggested the species as a synomym of $P$. bontanti (DE GRossouvRE), an Upper Coniacian species.

As Placenticeras species are unknown in Japan, the Santonian Stage in Japan cannot be directly correlated with the stratotype in France. But the base of the Santonian in Japan would be correlated with the currently known base of the stage if Texanites (Texanites) is usable as a marker. Similarly, the direct correlation of the lower Campanian in Japan with the stratotype is very difficult in the present state of our knowledge.

\section{Palaeontlogical notes of the selected species}

Family Inoceramidae ZITTEL, 1881

Genus Inoceramus SOWERBY, 1814

Subgenus Cordiceramus SEITZ, 1961

Inoceramus (Cordiceramus) kanmerai ToshIMITSU, 1986

1986. Inoceramus (Cordiceramus) kanmerai Toshimitsu, Proc. Japan Acad., vol. 62 (B), p. 227 , fig. 1 .

Pl. 24, Fig. 2

Remarks.-This species was recently established by TosHImitsu (1986) with a full description based on the holotype and paratype specimens, so no further notes are needed. In that paper was noted that the species has a range from the uppermost Santonian to the Lowest Campanian, but now it is revised to be restricted to the Lowest Campanian.

\section{Genus Sphenoceramus Вöнм, 1915 \\ Sphenoceramus africanus (HEINZ, 1930)}

1930. Inoceramus africanus HEINZ (nom. nud.), in BESAIRIE, Rech. geol. Madagascar., p. 128.

1933. Mytiloides africanus HeInz, Z. Deutsch. Geol. Gesellsch., vol. 85, p. 249, pl. 21, figs. 3-4.

1964. Inoceramus (Sphenoceramus?) africanus; SoRNAY, Ann. Paléont., Invertébré, vol. 50, p. 12 , pl. 11, fig. 4 .

Pl. 27, Figs. 9a, b

Material.-Specimen GK. H8135 from loc. RH2511k1 and GK. H8136 from loc. RK3010p3 (left valves) and GK. H8137 from RK0005a5 (articulate valve).

Descriptive remarks.--Shell small, relatively convex owing to somewhat secondary depression which makes an apparent anterior shoulder between the steeply inclined anterior side and the main part of disk. Obliquity moderate $\left(\delta=59^{\circ}\right)$. Posterior wing fairly broad, unclearly demarcated from the main disk with a slight difference in level in a specimen from RH2511k1, but definitely in other two specimens. Hinge-line about a half of shell-length, with on acute 
anterior angle $\left(\alpha=72^{\circ}\right)$ and obtuse posterior one $\left(\gamma=135^{\circ}\right)$. Umbonal inflation acute $\left(\beta=47^{\circ}\right)$. A faint shallow posterior radial sulcus is discernible. Ventral margin asymmetrically rounded, passing into gently arcuate anterior margin and nearly straight posterior one. Shell ornamented with numerous, regular concentric rings on the regular concentric undulations or ribs, which continue onto the posterior wing.

These specimens resemble the holotype of S. africanus of HEINZ (1933, pl. 21, fig. 3) in the outline and ornamentation, although they have a smaller shell and a slightly smaller apical angle.

Measurements (in $\mathrm{mm}$ ).-

$\begin{array}{lllllllllllllll}\text { specimens } & \mathrm{h} & \mathrm{l} & \mathrm{l} / \mathrm{h} & \mathrm{H} & \mathrm{L} & \mathrm{L} / \mathrm{H} & \mathrm{b} & \mathrm{b} / \mathrm{h} & \mathrm{s} & \mathrm{s} / \mathrm{l} & \alpha & \beta & \gamma & \delta\end{array}$

GK. H8135 $32.528 .0 .8637 .0(20.5)(.55)(11.0)(.34)(14.0)(.50)\left(72^{\circ}\right)\left(47^{\circ}\right) 135^{\circ} 59^{\circ}$

For letters see Matsumoto and NoDA (1985). The parentheses show an approximate value.

Occurrence.-The specimen from RH2511k1 of the Nakanofutamata-gawa, occurs in sandy siltstone of the lower part' of the Upper Haborogawa Formation. Those from RK0005a5 of the Kotanbetsu River and RK3010p3 of the Onkonosawa occur in sandy siltstone of the upper part of the Upper Haborogawa Formation.

\section{Sphenoceramus sanrikuensis Matsumoto and SugIYama, 1985}

1985. Sphenoceramus sanrikuensis Matsumoto and SugrYama, Proc. Japan Acad,, vol. 61 (B), p. 106, fig. 2.

1986. Sphenoceramus sanrikuensis Matsumoto and Sugryama, Bull. Iwate Pref. Mus. (4), p. 21, pl. 3, figs. 1-12.

Pl. 27, Figs. 4, 5

Remarks.-This species was recently established by Matsumoto and SugiYAMA (1985) and described in more detail in Japanese (MATSUMoTo and SUGIYAMA, 1986). Although there are some variations in the ornamentation and the extent of posterior wing, the specimens examined in this paper are so similar to the type specimens that they can be identified with this species.

Occurrence.-Most of the specimens examined occur in claystone and siltstone of the middle and upper parts of the Upper Haborogawa Formation in the Haboro, Kotanbetsu and Obira areas, and some are from siltstone of IIId member in the Saku area (MATSUMото, 1942b, p. 200).

Sphenoceramus sp. nov.(?) aff. S. lingua GoLDFUss, 1835

Pl. 27, Figs. 10a, b, 11a, b

Material.-Specimen USR101 and 102, a pair of inarticulate right and left valves collected from a floated nodule by S. UcHIDA at loc. Rh-12p in a small branch of Nakanofutamata-gawa (H-29). Left valve (GK. H8138) from a floated nodule at loc. RK3003p1 and two left valves (GK. H8139 and 8140) from loc. RK3012a along the Onkono-sawa.

Description.-Shell small, moderately convex and equivalve, extending relatively obliquely to the posteroventral margin with a straight growth axis. The 
features of the posterior wing uncertain because of its poor preservation. Anterior margin very gently arcuate, ventral margin asymmetrically and fairly narrowly rounded, and posterior margin long and straight. Three radial ridges developed along the anterior margin, growth axis and boundary between the main disk and posterior wing. Sulcuses discernible between the anterior and central ridges and between the central and posterior ones. Anterior sulcus clearer than posterior one. Main part of disk ornamented with numerous, regular concentric rings, but typical double rings not observed.

\section{Explanation of Plate 27}

Fig. 1. Sphenoceramus schmidti (MICHAEL)

GK. H8236 from loc. RH5007j1 in the Chimei-zawa. Right valve. $\times 1$.

Fig. 2. Sphenoceramus schmidti (MICHAEL)

GK. H8237 from loc. KTA020g in the Tanno-sawa of the Saku area. Left valve. $\times 1$.

Fig. 3. Sphenoceramus orientalis (SokoLow) GK. H8257 from loc. KTA020g in the Tanno-sawa. Left valve. $\times 1$.

Fig. 4. Sphenoceramus sanrikuensis MATSUmoto and SUgIYAMA GK. H8238 from loc. RH7176a1 in the Detofutamata-gawa, collected by $\mathrm{S}$. UCHIDA and S. T. Left valve. $\times 1$.

Fig. 5. Sphenoceramus sanrikuensis Matsumoto and SugIYama GK. H8239 from loc. R346p6 in the Migino-sawa. Left valve. $\times 1$.

Fig. 6. Sphenoceramus cristatus sp. nov.

GK. H8177 from loc. RK3002p2 in the Onkono-sawa, collected by S. UCHIDA and S. T. Lateral view of the left valve (a); anterior view (b) ; dorsal view (c). $\times 1.5$.

Fig. 7. Sphenoceramus cristatus sp. nov.

GK. H8166, holotype from loc. RK3020i in the Onkono-sawa, collected by S. UCHIDA and S. T. Lateral view of the left valve (a); anterior view (b) ; dorsal view (c). $\times 1$.

Fig. 8. Sphenoceramus sp. aff. S. cristatus sp. nov.

GK. H8195 from loc. RK1007b3 along the Kamino-sawa. Lateral view of the left valve (a); anterior view (b). $\times 2$.

Fig. 9. Sphenoceramus africanus (HEINZ)

GK. H8135 from loc. RH2511k1 in the Nakanofutamata-gawa. Lateral view of the left valve (a) and anterior view (b). $\times 1$.

Fig. 10. Sphenoceramus sp. aff. S. lingua GoLDFUss

USR101 from loc. Rh12p in the small branch of the Nakanofutamata-gawa, collected by S. UCHIDA. Lateral view of the right valve (a) and anterior view (b). $\times 1$.

Fig. 11. Sphenoceramus sp. aff. S. lingua GoLDFUsS

USR102 from loc. Rh12p in the small branch of the Nakanofutamata-gawa, collected by S. UcHidA. Lateral view of the left valve (a) and anterior view (b). $\times 1$.

Fig. 12. Sphenoceramus haboroensis sp. nov.

GK. H8198, holotype from loc. RH7176c1 in the Detofutamata-gawa, collected by S. UCHIDA and S. T. Lateral view of the right valve (a) and anterior view (b). $\times 1$.

Fig. 13. Sphenoceramus kiritachiensis sp. nov.

GK. H8201, holotype from loc. RK0011a9 in the Kotanbetsu River. Lateral view of the right valve (a); oblique view (b); anterior view (c). $\times 1$. 


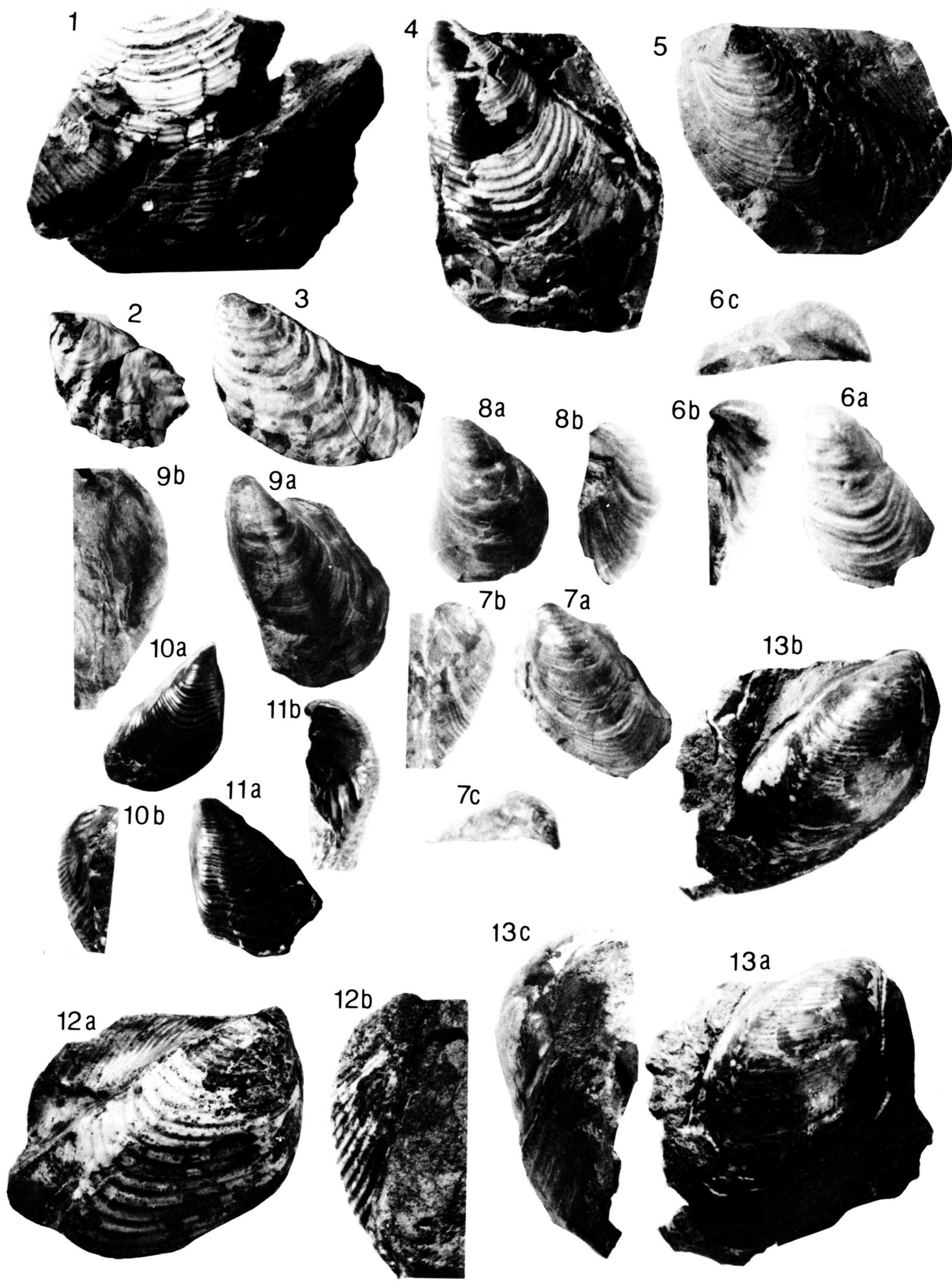

S. Toshimitsu: Biostratigraphy of the Santonian 

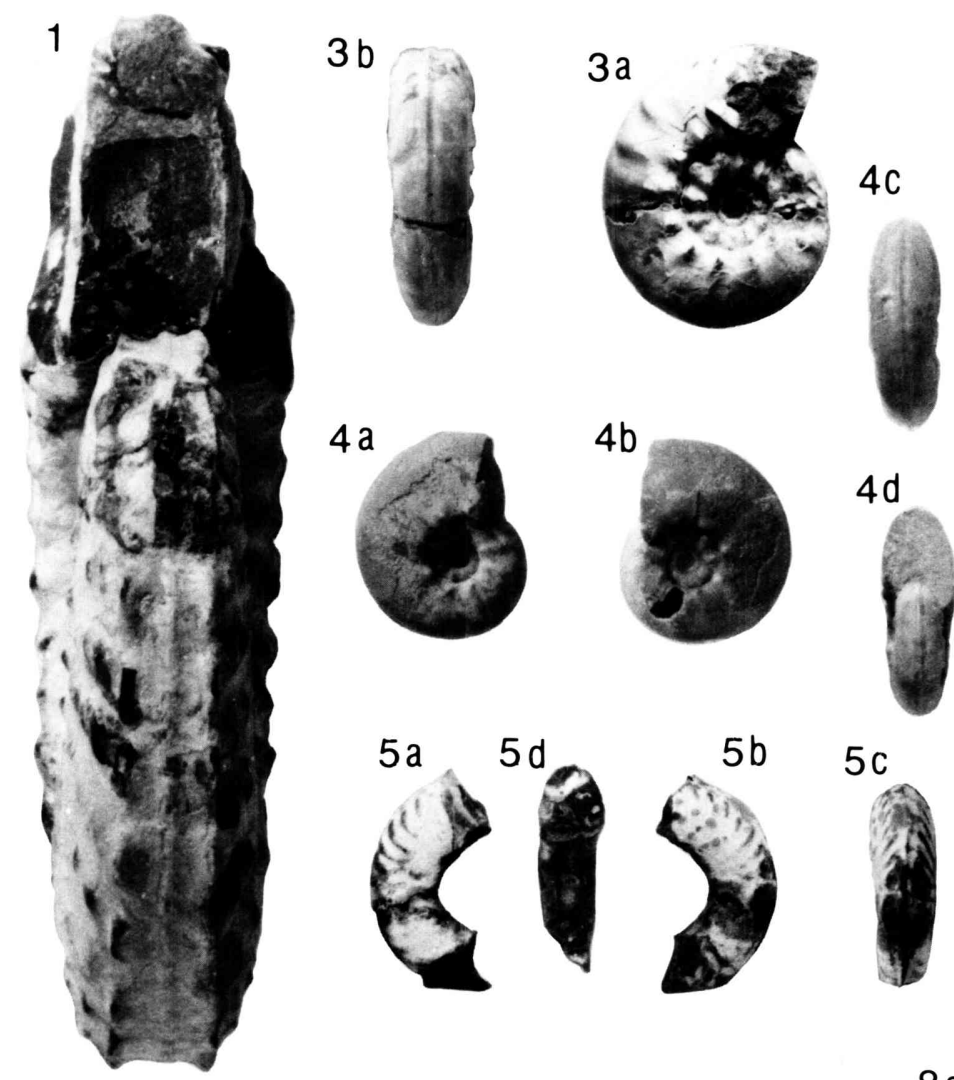

$5 c$
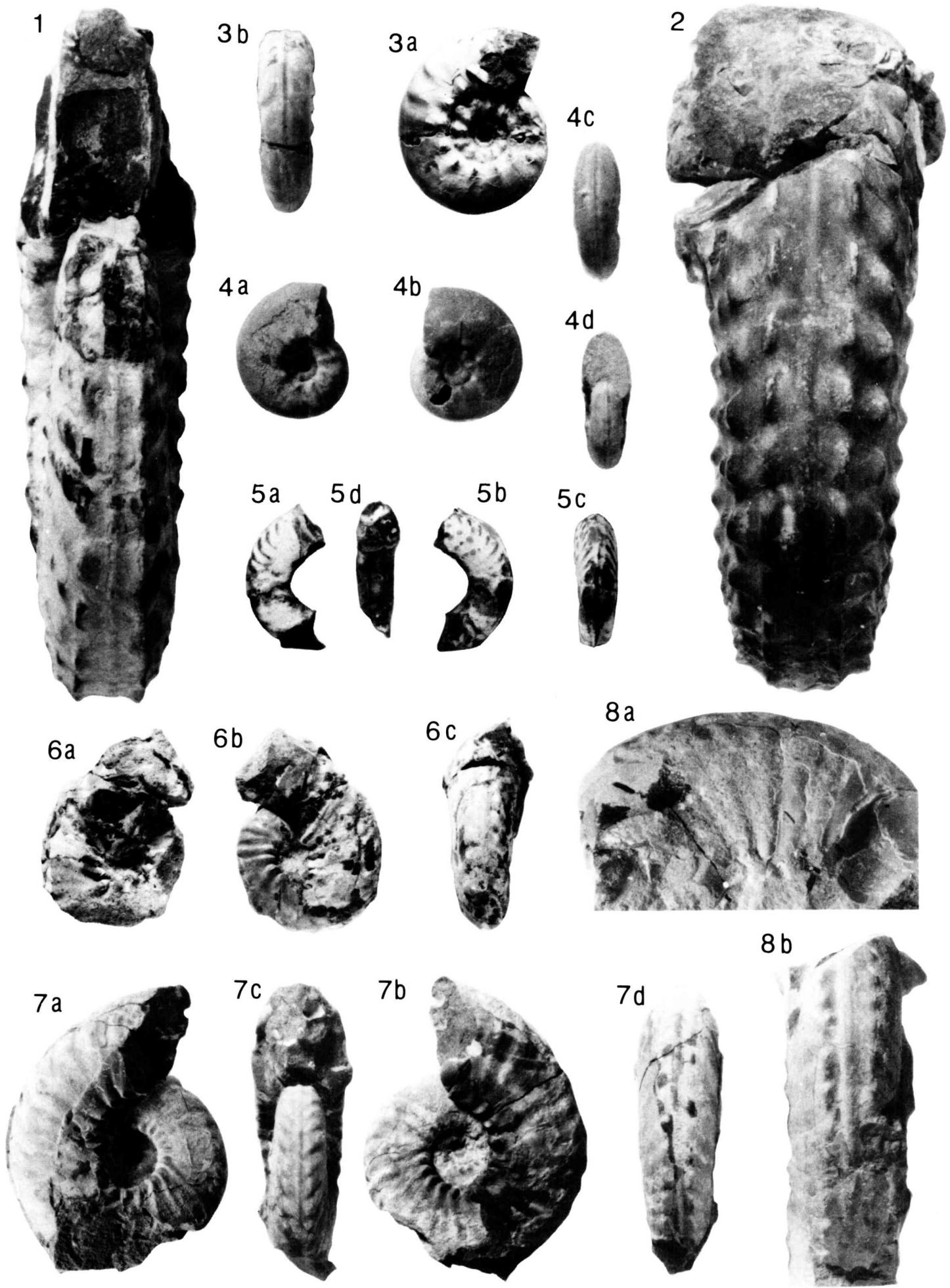

S. Toshimitsu: Biostratigraphy of the Santonian 
Measurements (in $\mathrm{mm}$ ).-

$\begin{array}{lccccccccccc}\text { specimens } & \text { h } & \text { l } & \text { H } & \text { L } & \text { L/H } & \text { b } & \text { s } & \alpha & \beta & \gamma & \delta \\ \text { USR102 } & - & - & 25.0 & 18.5 & .72 & 9.0 & - & - & 59^{\circ} & - & - \\ \text { USR101 } & - & - & 22.5 & 15.0 & .66 & 7.5 & - & - & 52^{\circ} & - & -\end{array}$

Remarks.-These specimens resemble $S$. lingua (see SeITZ, 1965, pl. 16, fig. 4) and $S$. juv. cf. lingua (SEITZ, 1965, pl. 18, fig. 3, 5), but the latter two have neither anterior ridge nor anterior sulcus. They are also similar to S. cardissoides (GoldFUSS), S. pinniformis (WILLET) and S. patootensiformis (SEITZ, 1965), but the latter species have much coarser ornamentation and well-developed radial pits.

Occurrence.-The specimens USR101 and 102 were collected from a floated silty calcareous nodule at loc. Rh-12p of S. UcHIDA along the route H-29. GK. H8139 to 8141 were obtained from sandy siltstone along the Onkono-sawa. The localities of these four specimens belong to the upper part of the Upper Haborogawa Formation.

Sphenoceramus cristatus sp. nov.

Pl. 27, Figs. 6a-c, 7a-c

Material.-The holotype (GK. H8166; Pl. 27, Figs. 7a-c) is a left valve collected by S. UCHIDA and S. Toshimitsu from loc. RK3020i along the Onkonosawa. Other specimens came from the following localities. Specimens marked with * are from floated nodules:

\section{Explanation of Plate 28}

Fig. 1. Plesiotexanites pacificus (MATSUmoto)

Frontal view of GK. H8242. $\times 1$.

Fig. 2. Plesiotexanites kawasakii (KAWADA)

Ventral view of GK. H8243. $\times 1$.

Fig. 3. Protexanites (Miotexanites) minimus Matsumoto

GK. H8207, ornate form, from loc. RH3126 in the Kotodo-zawa. Lateral view (a); ventral view (b). $\times 2$.

Fig. 4. Protexanites (Miotexanites) minimus Matsumoto

GK. H8214, smooth form, from loc. RK1007b3 in the Kamino-sawa. Lateral view $(a, b)$; ventral view $(c)$; frontal view $(d) . \times 2$.

Fig. 5. Haboroceras sp. aff. $H$. haboroense sp. nov.

GK. H8226 from loc. RH2873b5 in the Shimizu-zawa. Lateral views (a, b) ; ventral view (c); cross-section (d). $\times 2$.

Fig. 6. Protexanites (Protexanites) bontanti shimizui Matsumoto

GK. H8246 from loc. RH1200g, a road-cut on the Sakasagawa Forest Road, collected by T. Matsumoto, M. NodA, S. Uchida and S. T. Lateral views $(a, b)$; ventral view $(c) . \times 1$.

Fig. 7. Protexanites (Anatexanites) fukazawai (YABE and SHIMIZU)

GK. H8245 from loc. RH7239a in the Pisshiri-zawa, collected by S. UCHIDA and S. T. Lateral views $(a, b)$; frontal view $(c)$; ventral view $(d) . \times 1$.

Fig. 8. cf. Plesiotexanites shiloensis (Young)

GK. H8247 from loc. RH5047c6 in the Chimei-zawa. Lateral view (a); ventral view (b). $\times 1$. 
Right valve-RH346p6* (GK. H8141, 8143), RH2532i (GK. H8144), RH7176b7 (GK. H8145), RH7176c4 (GK. H8150), RH7311b1 (GK. H8151) in the Haboro area, RK0011a13 (GK. H8153), RK3014p1* (GK. H8154, 8155, 8156), RK3015d (GK. H8159), RK3105p2* (GK. H8161, 8162), RK3018a (GK. H8163), RK3020n (GK. H8165), RK3218a3 (G.K H8167, 8168) in the Kotanbetsu area, KTA008r1 (GK. H8176), KTA008r2 (GK. H8171) in the Saku area.

Left valve-R346p6* (GK. H8142), RH7176b7 (GK. H8146 to 8149), RH7176cr1 (GK. H8172) in the Haboro area, RK0011a8 (GK. H8173), RK0011a9 (GK. H8174), RK0011a11 (GK. H8175), RK0011a13 (GK. H8152), RK0017a1 (GK. H8176), RK3002p2* (GK. H8177), RK3009p1* (GK. H8178), RK3011a (GK. H8179, 8180), RK3011r1 (GK. H8181, 8189), RK3015d (GK. H8157, 8158, 8160), RK3015g (GK. H8182), RK3018a (GK. H8164), RK3019a (GK. H8183), RK3020e (GK. H8184, 8185), RK3206a (GK. H8186, 8187), RK3218a3 (GK. H8188) in the Kotanbetsu area.

Description.-Shell small, equivalve, inequilateral and convex, extending obliquely from beak to posteroventral extremity, with a nearly straight growth axis which forms an angle $(\delta)$ of $47^{\circ}$ to $62^{\circ}$ with the hinge-line. Umbo terminal, slightly prominent and incurved. Valve much inflated in the umbonal part and gently in the ventral part, with convexity changing rapidly with 2 steps in the early and middle growth stages. Posterior wing moderately broad with some variation, definitely demarcated from the main part of disk. Length of hingeline uncertainly, with an anterior angle $(\alpha)$ of $70^{\circ}-80^{\circ}$ and a probably obtuse posterior angle (not precisely measured), while an angle $(\beta)$ of umbonal inflation acute $\left(44^{\circ}-60^{\circ}\right)$. Anterior margin nearly straight or somewhat convex; ventral margin asymmetrically and fairly narrowly rounded; posterior margin long and nearly straight.

Test thin, but for somewhat thick hinge plate. Three radial ridges of unequal and variable strength. Shallow radial sulcuses developed in some case between the anterior and central ridges and between the central and posterior ones. Main part of disk ornamented with small and irregular concentric undulations and numerous, regular concentric rings, some of which may be united near the margin but do not form typical double rings. These ornaments weaken or disappear on the posterior wing.

\begin{tabular}{|c|c|c|c|c|c|c|c|c|c|c|c|c|c|}
\hline \multicolumn{14}{|c|}{ Measurements (in $\mathrm{mm}$ ).- } \\
\hline $\begin{array}{l}\text { specimens } \\
\text { Left valve }\end{array}$ & $\mathrm{h}$ & 1 & $1 / \mathrm{h}$ & H & $\mathrm{L}$ & $\mathrm{L} / \mathrm{H}$ & b & $\mathrm{b} / \mathrm{h}$ & $\mathrm{s}$ & $\alpha$ & $\beta$ & $\gamma$ & $\delta$ \\
\hline 010 & 25.0 & 25.0 & 1.00 & 31.0 & $(20.0)$ & $(.65)$ & 10.5 & .42 & - & $84^{\circ}$ & $60^{\circ}$ & - & \\
\hline 175 & 10.5 & 12.5 & 1.19 & 14.5 & 10.0 & .69 & 4.5 & .43 & - & $59^{\circ}$ & & - & \\
\hline GK. & 18.0 & 5.0 & .83 & 20.5 & 13.0 & .63 & 5.5 & .31 & - & $83^{\circ}$ & - & 一 & \\
\hline & 18.5 & 18.0 & 1.00 & 22.5 & 12.5 & .56 & 12.0 & .65 & - & $73^{\circ}$ & $44^{\circ}$ & - & \\
\hline GK. & 8.0 & 9.0 & 1.13 & 11.0 & 7.0 & .64 & 3.5 & .44 & - & $78^{\circ}$ & $50^{\circ}$ & 一 & \\
\hline GK. & 15.5 & 16.5 & 1.06 & 19.0 & 14.5 & .76 & 7.0 & .45 & - & $80^{\circ}$ & $59^{\circ}$ & - & \\
\hline & 10.5 & 10.5 & 1.00 & 13.0 & 8.5 & .65 & 6.5 & .62 & - & $77^{\circ}$ & $54^{\circ}$ & - & \\
\hline & 12.0 & 13.5 & 1.13 & 15.0 & 10.0 & .67 & 7.0 & .58 & - & $67^{\circ}$ & $47^{\circ}$ & - & \\
\hline & 10.0 & 8.5 & .85 & 11.5 & 7.0 & .61 & 3.0 & .30 & - & $74^{\circ}$ & $48^{\circ}$ & - & \\
\hline & & & & & & & & & & & & & \\
\hline H8150 & 7.5 & 10.0 & 1.33 & 11.0 & 6.9 & .59 & 3.0 & .40 & - & $59^{\circ}$ & $53^{\circ}$ & - & \\
\hline
\end{tabular}


$\begin{array}{lrrrrrrrrrr}\text { GK. H8151 } & 11.5 & 10.5 & .91 & 13.0 & 9.0 & .96 & 3.0 & .26 & -80^{\circ} 58^{\circ}-59^{\circ} \\ \text { GK. H8159 } & 7.5 & 8.5 & 1.13 & 9.5 & 7.0 & .74 & 3.5 & .47-68^{\circ} 60^{\circ}-38^{\circ}\end{array}$

Remarks.-This species resembles S. sanrikuensis, S. naumanni and S. yokoyamai, but it is distinguished by its radial ridges and much inflated valves. It is also similar to $S$. lingua, $S$. cf. lingua and $S$. juv. cf. lingua (see SEITZ, 1965), but it has three radial ridges, a much smaller shell and denser ornamentations than the latter species.

Occurrence.-The specimens from the Haboro and Kotanbetsu areas occurred in sandy mudstone of the upper part of the Upper Haborogawa Formation. Those from the Saku area also occurred in sandy mudstone.

Shenoceramus sp. aff. S. cristatus sp. nov.

Pl. 27, Figs. 8a-b

Material.-Right valve (GK. H8192) from loc. RH7239a in the Detofutamatagawa.

Left valves from loc. RH5049c4 (GK. H8193) in the Chimei-zawa, locs. RH7239a (GK. H8190, 8191) and RH7013a (GK. H8194) in the Detofutamatagawa, and loc. RH1007b3 (GK. H8195 to 8197) in the Kamino-sawa.

Description.-Shell small, very convex in the early growth stage, but moderately convex later with two changing points of shell growth in the early and middle stages, extending obliquely to the posteroventral margin, with a straight growth axis which forms an angle $(\delta)$ a little less than $50^{\circ}$ with the hinge-line. Posterior wing weakly developed. The angle $(\alpha)$ between hinge-line and anterior margin acute but somewhat variable. The angle $(\beta)$ of umbonal inflation acute $\left(\mathrm{ca} .50^{\circ}\right.$ ). Anterior margin nearly straight or very gently arcuate; ventral margin asymmetrically and fairly narrowly rounded; posterior margin nearly straight. Three very faint radial ridges observed in the earlier growth stage, but undiscernible in the later stage. Main part of disk ornamented with numerous, regular concentric rings and occasionally with irregular and faint, concentric major undulations.

\begin{tabular}{lrrrrrrrrrrrrr}
\multicolumn{3}{l}{ Measurements (in $\mathrm{mm}$ ).- } \\
specimens & \multicolumn{1}{c}{$\mathrm{h}$} & $\mathrm{l}$ & $\mathrm{l} / \mathrm{h}$ & $\mathrm{H}$ & $\mathrm{L}$ & $\mathrm{L} / \mathrm{H}$ & $\mathrm{b}$ & $\mathrm{b} / \mathrm{h}$ & $\mathrm{s}$ & $\alpha$ & $\beta$ & $\gamma$ & $\delta$ \\
GK. H8193 & 15.0 & 15.5 & 1.03 & 19.5 & 11.0 & .56 & 6.0 & .40 & - & $28^{\circ}$ & $47^{\circ}$ & $\left(131^{\circ}\right)$ & $48^{\circ}$ \\
GK. H8190 & 9.0 & 13.0 & 1.44 & 13.5 & 8.5 & .63 & 5.5 & .61 & - & $65^{\circ}$ & $50^{\circ}$ & - & $47^{\circ}$
\end{tabular}

Remarks. $-S$. aff. cristatus shows variation in development of three radial ridges and in feature of concentric ornamentation, but the angle $\beta$ and $\delta$ are relatively stable.

This species resembles $S$. cristatus, but it is distinguished by its weak radial ridges. It is distinguished from $S$. naumanni by its radial ridges and more irregular convexity. It differs from Inoceramus talovensis PERGAMENT (1974, pl. 12, figs. 3-6) in having three weak radial ridges and more acute umbonal inflation.

Occurrence.-These specimens occur in siltstone calcareous nodule in the lower part of the Upper Haborogawa Formation of the Haboro and Kotanbetsu areas. 
Sphenoceramus haboroensis sp. nov.

Pl. 27, Figs. 12a-b

Material.-Holotype (GK. H8198), a right valve collected by S. UCHIDA and S. ToshImitsu from loc. RH7176c1 in the Detofutamata-gawa. Other imperfectly preserved specimens referable to this species came from loc. RH7176a1 (GK. H8199) in the Detofutamata-gawa and loc. RK3015b (GK. H8200) in the Onkonosawa.

Specific characters.--Shell small, subrhomboidal in general outline, moderately convex, extending very obliquely to the posteroventral extremity with a nearly straight growth-axis which forms an angle $(\beta)$ of about $50^{\circ}$ with the hingeline. Posterior wing fairly broad, definitely demarcated from the main part of disk. Hinge-line about three-fifths of shell-length, with an obtuse anterior $\left(\alpha=110^{\circ}\right)$ and posterior angle $\left(\gamma=145^{\circ}\right)$, but the angle $(\beta)$ of umbonal inflation somewhat acute $\left(81^{\circ}\right)$. Anterior margin gently convex, turning abruptly to the ventral margin, which is nearly straight or gently concave on the anterior half of the valve and asymmetrically and fairly narrowly rounded on the central part; posterior margin long and nearly straight, but the posterodorsal margin abruptly turned toward the umbo to merge into the hinge-line. Three weak radial ridges perceptible; the first close to the anterior margin, the second along the growth axis and the third along the boundary between the main disk and the posterior wing. A faint sulcus developed between the central and posterior ridges.

Test relatively thin, but somewhat thicker on the posterior wing. Main part of disk ornamented with numerous, regular concentric ribs, but numerous and dense striae run on the posterior wing in parallel with posterior margin.

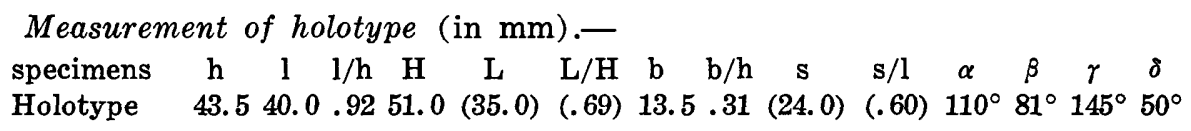

Remarks.-This species is distinguished from S. sanrikuensis by its subrhomboidal outline, larger convexity and coarser ornamentation.

$S$. haboroensis differs from $S$. lingua, $S$. cf. lingua and $S$. juv. cf. lingua of SEITZ (1965) in having a broader posterior wing, larger convexity of valves and long and straight or slightly concave anteroventral margin.

Occurrence.-The holotype and two conferable specimens were obtained from sandy siltstone in the upper part of the Upper Haborogawa Formation along the Detofutamata-gawa of Haboro and the Onkono-sawa of the Kotanbetsu River.

Sphenoceramus kiritachiensis sp. nov.

P1. 27, Figs. 13a-c

Material.-Holotype (GK. H8201a), a right valve from RK0011a9 in the Kotanbetsu River. Other specimens are GK. H8201b (left valve) associated with holotype, GK. H8202 (articulate valves) from loc. RH5007j5 in the Chimei-zawa, GK. H8203 (right valve) from loc. RH7176b7 in the Detofutamata-gawa. A conferable specimen (GK. H8204) from loc. RH7176a1 in the Detofutamata-gawa (right valve). 
Specific characters.-Shell small, very convex, extending very obliquely to the posteroventral extremity with a straight growth-axis which forms an angle $(\delta)$ of about $50^{\circ}$ with the hinge-line. Posterior wing fairly broad, definitely demarcated from the main part of disk. Hinge-line about two-thirds of shelllength, with obtuse anterior $\left(\alpha=\right.$ ca. $\left.100^{\circ}-120^{\circ}\right)$ and posterior angles $\left(\gamma=\right.$ ca. $\left.120^{\circ}\right)$, the angle $(\beta)$ of umbonal inflation ranging from $98^{\circ}$ to $64^{\circ}$. Anterior margin very gently arcuate with convex anterodorsal and anteroventral edges; ventral margin nearly straight on the anterior part and asymmetrically and fairly narrowly rounded on the central part of shell; posterior margin long and very gently arched, and the posterodorsal margin turning toward the umbo to merge into the hinge-line. Test relatively thin, but thick below the posterior wing. Main part of disk ornamented with numerous, regular concentric rings on the internal mould, but numerous and dense lirae and striae on the outer surface, running also on the posterior wing in parallel with posterior margin. Irregular concentric undulations weakly developed in the late growth stage.

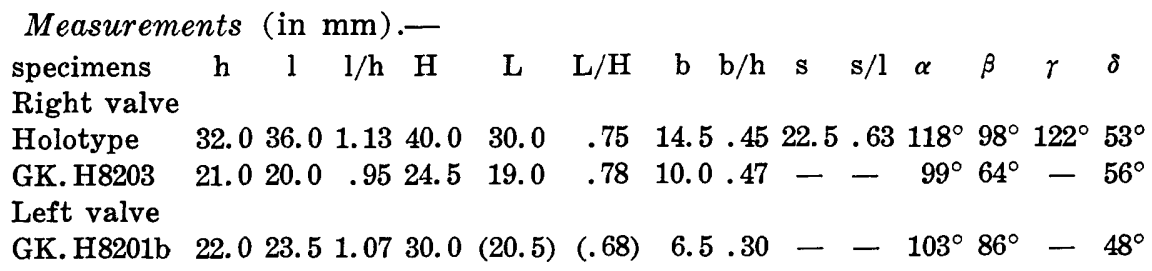

Remarks.-This species resembles $S$. haboroensis, but is distinguished in having much denser concentric rings, more convex valves and no radial ridges. $S$. kiritachiensis is distinguished from $S$. naumanni and $S$. yokoyamai by its broader posterior wing, subrhomboidal instead of sphenoid outline and more convex valve.

Occurrence.-The holotype and other specimens occurred in calcareous nodules of sandy siltstone in the upper part of the Upper Haborogawa Formation in the Haboro and Kotanbetsu areas.

Family Collignoniceratidae WRIGHT and WRIGHT, 1951

Subfamily Texanitinae Collignon, 1948

Genus Protexanites Matsumoto, 1955

Subgenus Miotexanites Matsumoto, 1970

Protexanites (Miotexanites) minimus Matsumoto, 1970

1970. Protexanites (Miotexanites) minimus Matsumoto, Mem. Fac. Sci. Kyushu Univ., ser. D, Geol., vol. 20, p. 246, pl. 33 [37], figs. 1-3.

Pl. 28, Figs. 3a, b, 4a-d

Material.-Specimens (GK. H8204, 8205) from loc. RH1204a and RH1267d in the Sakasa-gawa loc. RH2895e1 (GK. H8206) in the Shimizu-zawa, loc. RH3126 (GK. H8207, 8208) in the Kotodo-zawa, loc. RH5047c7 (GK. H8209) and RH5049c4 (GK. H8210) in the Chimei-zawa, loc. RH7207c1 (GK. H8211) in the Pisshiri-zawa, loc. RK0037f1 (GK. H8212) and RK0037j (GK. H8213) along the 
Kotanbetsu River, and loc. RK1007b3 (GK. H8214) in the Kamino-sawa. A conferable specimen (GK. H8215) from loc. RH5132c1 in the Chimei-zawa.

Remarks.-Protexanites (Miotexanites) minimus Matsumoto (1970) is monotypic. Its holotype (GK. H5166) is $52.5 \mathrm{~mm}$ in diameter and its inner whorl is also illustrated down to $5 \mathrm{~mm}$ in whorl height. Still younger part is not well shown. The specimens obtained from the Haboro and Kotanbetsu areas are mostly smaller than that inner whorl. However the narrow umbilicus, weak tubercles, the whorl sections and sutural pattern of these specimens are similar to those of inner whorls of the holotype. Therefore they are tentatively identified with $P$. (M.) minimus.

There are two types of ornamentation: the ornate form (e.g. GK. H8207, 8208) and the smooth form (e.g. GK. H8210, 8214). Both of them have relatively coarse and strong rectiradiate lateral ribs and ventrolateral tubercles on inner whorls. The former has weak but distinct ribs and ventrolateral tubercles on the outer whorl, while the latter is nearly smooth. There are no difference of stratigraphic distribution between the two forms.

$\begin{array}{ccccccc}\begin{array}{c}\text { Measurements } \\ \text { specimens }\end{array} & \text { (in } \mathrm{mm} \text { ) } & & & & & \\ \text { GK. H8204 } & 12.5 & 4.1 & .33 & 4.9 & 4.8 & .98 \\ \left(-180^{\circ}\right) & - & - & - & 3.9 & 3.8 & .97 \\ \text { GK. H8207 } & 13.8 & 5.8 & .42 & 4.9 & 4.4 & .90 \\ \text { GK. H8208 } & 12.2 & 4.5 & .32 & 4.6 & 4.0 & .87 \\ \text { GK. H8209 } & (12.0) & (4.7) & (.39) & - & - & - \\ \left(-180^{\circ}\right) & - & - & - & 3.5 & 3.3 & .94 \\ \text { GK. H8212 } & 7.2 & 2.3 & .32 & 3.7 & 3.3 & .89 \\ \text { GK. H8213 } & 13.8 & 5.8 & .42 & 5.3 & 4.5 & .85 \\ \text { GK. H8214 } & 10.5 & 3.3 & .31 & 4.7 & 3.4 & .72 \\ \left(-180^{\circ}\right) & - & - & - & 3.2 & 3.0 & .94\end{array}$

D: diameter, U: umbilicus, $\mathrm{H}$ : whorl-height, $\mathrm{B}$ : whorl-breadth

Occurrence.-The described specimens occurred in claystone and siltstone calcareous nodules of the middle and upper parts of the Middle Haborogawa Formation and the lower part of the Upper Haborogawa Formation in the Haboro and Kotanbetsu areas.

Genus Haboroceras gen. nov.

Type-species.-Haboroceras haboroense sp. nov. to be described below.

Generic diagnosis.- Shell small, discoidal and rather evolute with a somewhat narrow umbilicus. Whorl subquadrangular in coastal section and somewhat higher than broad.

Shell ornamented with faint, prorsiradiate and flexuous ribs, with frequent bifurcation or intercalation and with strong projection on venter, and tuberculation less developed. Entire ventral keel slightly undulated in correspondence with the ribbing.

Sutural pattern of collignoniceratid type, and pseudoceratitic. 
Haboroceras haboroense sp. nov.

Pl. 29, Figs. 3a-e

Material.-Holotype (GK. H8216) and another specimen (GK. H8217) are obtained from loc. RH1200f and 1204a, a road cut on the Sakasagawa Forest Road; collected by T. Matsumoto, M. NodA, S. UchidA and S. Toshimitsu. Some other specimens came from loc. RH1219a (GK. H8218) in the Sakasa-gawa, loc. RH4069a (GK. H8219) in the Otodo-zawa, and loc. RH5047c7 (GK. H8220, 8221), RH5049c4 (GK. H8222) and RH5086e2 (GK. H8223, 8224) in the Chimeizawa. Another conferable specimen (GK. H8225) from loc. R01047b along the Jugosen-zawa.

Description.-Shell very small, discoidal and rather evolute. Whorl somewhat higher than broad in the younger stage and much higher in the late stage. Venter gently arched, passing through the slant and blunt ventrolateral shoulders to the slightly convex or nearly flat and parallel flanks, and umbilical shoulder abruptly rounded, low wall surrounding somewhat narrow umbilicus.

Shell ornamented with very faint, prorsiradiate and flexuous ribs, with frequent bifurcation or intercalation on inner flank, and with strong projection on venter; median keel slightly undulated in correspondence with constriction and an associated flare runs near the apertural margin in the holotype. Constrictions may be marked on the earlier part of the body-chamber or even on the phragmocone. Umbilical tubercles faintly bullate and somewhat elevated at the umbilical shoulder, but other tubercles undeveloped. Ventral keel bordered by narrow and shallow furrows on both side.

Sutural pattern collignoniceratid and pseudoceratitic with undeveloped incision (Pl. 29, Fig. 3e). Lateral lobe (L) broad, shallowly incised toward the umbilicus but secondary lateral lobe (U2) very small. Lateral saddles massive and low.

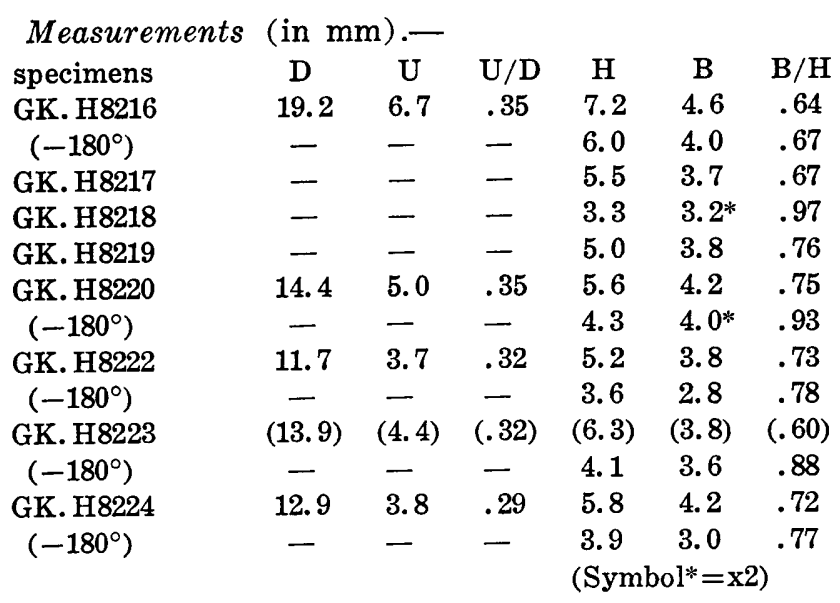

Remarks.-This species resembles the above-mentioned young shell of Protexanites (Miotexanites) minimus, but is distinguished in having smoother inner whorls and less incised suture, and a constriction near the apertural margin. 
Haboroceras haboroense is similar to Lymaniceras planulatum MATSUMото (1970, p. 31, pl. 6, figs. 1-2, pl. 7, figs. 1-5, pl. 8, figs. 1-8) from the uppermost Turonian in central Hokkaido, but the latter has more distinct ventrolateral tubercles and more finely serrated median keel. L. planulatum show a remarkable variation in the strength of ornaments, and the weakly ornamented specimens (Matsumoto, 1965, pl. 6, figs. 1-2) are closely similar to $H$. haboroense. Therefore this species may be a homeomorphy of $L$. planulatum.

Occurrence.-Most of the examined specimens occurred in claystone and siltstone restrictedly in the middle part of the Upper Haborogawa Formation of the Haboro area. A specimen which is to be called Haboroceras(?) cf. $H$. haboroense was obtained from claystone of the uppermost part of the Middle Haborogawa Formation along the Jugosen-zawa.

Haboroceras sp. aff. $H$. haboroense sp. nov.

Pl. 28, Figs. 5a-d

Material.-Two specimens (GK. H8226, 8227) from loc. RH2873b5 in the Shimizu-zawa.

Remarks.-Only two small fragmentary specimens are available for this study. Their ribs on the body chamber are somewhat coarser and stronger and their whorls are broader than those of Haboroceras haboroense. Tuberculation is undeveloped. Their suture pattern resembles that of Haboroceras haboroense. Thus these two specimens are allied to Haboroceras haboroense, but cannot be identified with it.

\begin{tabular}{lcccccc} 
Measurements & \multicolumn{2}{l}{ (in $\mathrm{mm}$ ). -} & & & & \\
specimens & $\mathrm{D}$ & $\mathrm{U}$ & $\mathrm{U} / \mathrm{D}$ & $\mathrm{H}$ & $\mathrm{B}$ & $\mathrm{B} / \mathrm{H}$ \\
GK. H8226 & - & - & - & 4.1 & 3.2 & .78 \\
GK. H8227 & - & - & - & 3.1 & 2.5 & .81
\end{tabular}

Occurrence.-The above-mentioned two specimens occurred from claystone calcareous nodule in the upper part of the Middle Haborogawa Formation.

Genus Submortoniceras SPATH, 1921

\section{Explanation of Plate 29}

Fig. 1. Submortoniceras sp. cf. S. condamyi CoLlignon

GK. H8228 from loc. RH7013a, a road-cut on the Simofutamata Forest Road, collected by Y. KANIE and S. T. Lateral views ( $a, b)$; frontal view (c); ventral view $(d) . \times 1$.

Fig. 2. Metaplacenticeras subtilistriatum (JIMBo)

GK. H8249 from loc. KTG043a in the Gakkono-sawa in the Saku area. Lateral views $(a, b)$; cross-section (c); ventral view (d). $\times 1$.

Fig. 3. Haboroceras haboroense sp. nov.

GK. H8216, holotype, from loc. RH1200f, a road-cut on the Sakasagawa Forest Road, collected by T. MATSUMOTo, M. NODA, S. UCHIDA and S. T. Lateral views $(a, b)$; ventral view $(c)$; frontal view $(d), \times 2$; suture line $(e)$, scale $\mathrm{bar}=1 \mathrm{~mm}$. $\mathrm{S}$ indicates the position of the suture line sketched. 

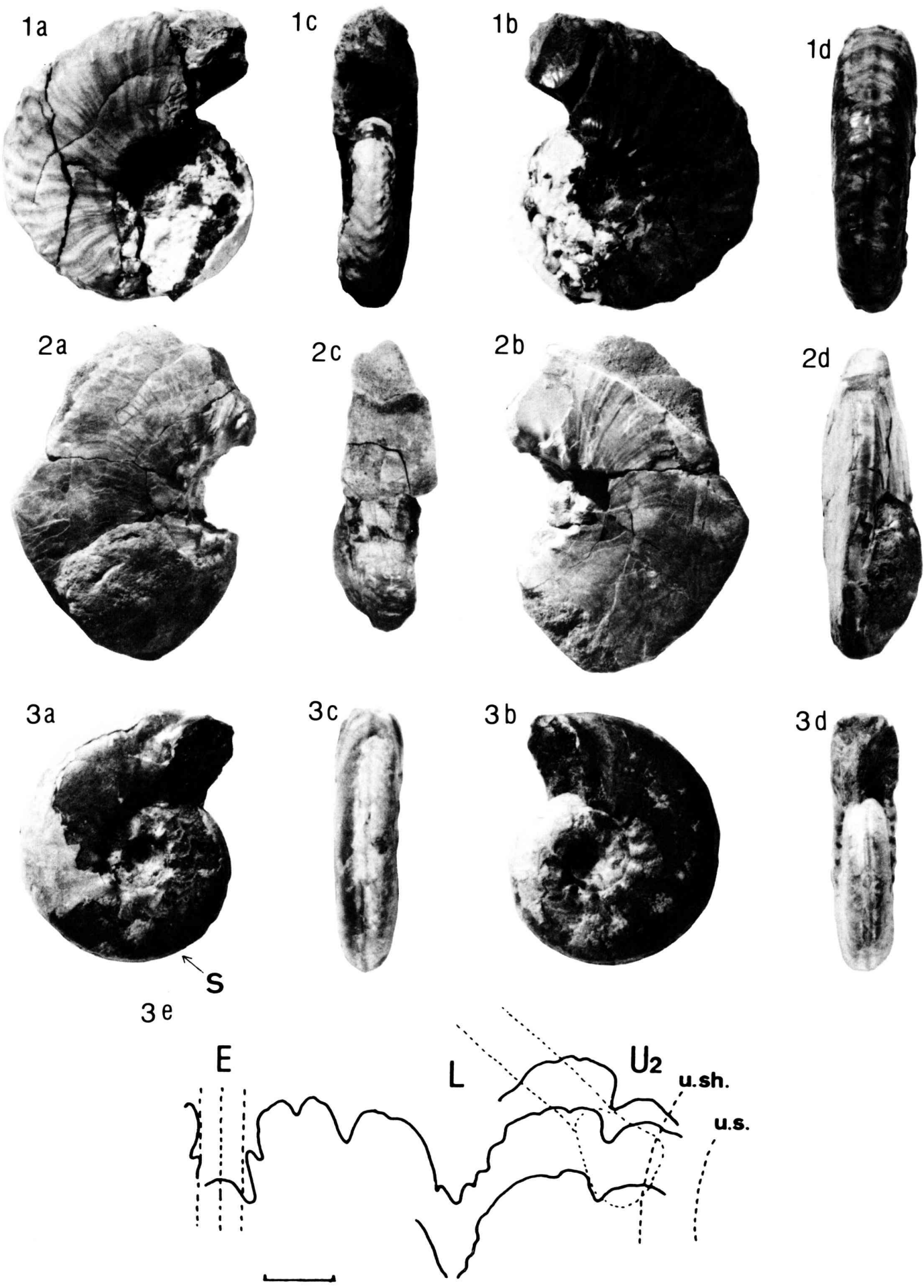

S. Toshimitsu: Biostratigraphy of the Santonian 
Submortoniceras sp. cf. S. condamyi (CoLlignoN, 1932)

1932. Mortoniceras condamyi Collignon, Ann. Paléont., vol. 9, p. 36, pl. 5, fig. 3-3b.

1948. Submortoniceras condamyi, (Collignon); Collignon, Ann. Géol. Serv., vol. 13 , p. 100, pl. $18(12)$, fig. 2-2b, pl. 15, fig. 1.

1980. Submortoniceras condamyi s. 1. (Collignon); KLINGER and KenNedy, Ann. S. Afr. Mus., vol. 80, p. 260, figs. 200a, 201-209, 212-213.

Pl. 29, Figs. 1a-d

Material.-A specimen (GK. H8228) from loc. RH7013a, at a road-cut on the Shimofutamata Forest Road; collected by Y. KANIE and S. ToshImitsu. A specimen (GK. H8229) from loc. RH7302a1, at a road-cut on the Nakafutamatagoe Forest Road.

Remarks.-The specimens obtained in the Haboro area are small, but their weak ornamentation and whorl sections agree to those of Submortoniceras. CollignoN (1948a, b) established many species of this genus in Madagascar, and Matsumoto (1959) suggested Collignon's species may be grouped into a small number of species. KLINGER and KENNEDY (1980) described Submortoniceras woodsi s. l. (SPATH) and S. condamyi s. l. of Zululand, and pointed out that some of CollignoN's species are synonyms of these species. Although there are a few differences between the two specimens, GK. H8228 and 8229, that is, the former has a wider whorl section and stronger ribs than the latter, their narrow umbilicus $(\mathrm{U} / \mathrm{D}=30 \%)$ is compatible with that of $S$. condamyi s.l. As the crenulated venter observed in the Haboro specimens has not been reported in Zululand and Madagascar specimens, the former may be differentiated from the latter. But the characters of the young stage of the specimens from Zululand and Madagascar have not been described. Under these circumstances, the two specimens from Haboro are tentatively referred to $S$. condamyi.

\begin{tabular}{lcccccc} 
Measurements & \multicolumn{2}{c}{ (in $\mathrm{mm}$ ) - -} & & & & \\
specimens & $\mathrm{D}$ & $\mathrm{U}$ & $\mathrm{U} / \mathrm{D}$ & $\mathrm{H}$ & B & B/H \\
GK. H8228 & 42.0 & 12.5 & .30 & 19.0 & 13.0 & .68 \\
GK. H8229 & - & - & - & 11.1 & 9.5 & .86 \\
$\left(-180^{\circ}\right)$ & - & - & - & 5.3 & 4.3 & .81
\end{tabular}

Occurrence.-These two specimens occurred in siltstone calcareous nodules in the middle part of the Upper Haborogawa Formation along the Detofutamatagawa, Haboro.

The repositories of the above mentioned specimens are: Geological Collections, Kyushu University, Fukuoka [GK], and Uchida Specimen Room, Iwamizawa [USR].

\section{Conclusion}

(1) The Cretaceous Upper Yezo Group exposed in the Haboro area consists of the Lower, Middle and Upper Haborogawa Formations, which are also recognized in the northerly adjacent Chikubetsu and the southerly neibouring Kotanbetsu and Obira areas. 
(2) Through the biostratigraphic study of the Middle and Upper Haborogawa Formations, the following conclusions are made:

a) These formations can be divided into four zones by means of inoceramids, i.e., in ascending order, the Inoceramus uwajimensis-I. mihoensis Zone, the $I$. amakusensis Zone, the Platyceramus japonicus Zone, the Sphenoceramus orientalis Zone and S. schmidti Zone. The subzone of $S$. sanrikuensis-S. cristatusInoceramus (Cordiceramus) kanmerai can be established in the upper main part of the P. japonicus Zone.

b) The succession from the middle part of the Middle Haborogawa Formation to the middle part of the Upper Haborogawa Formation is divisible into two zones on the basis of texanitine ammonites, i.e. the zone of Texanites collignoni-T. quinquenodosus below and the zone of Plesiotexanites kawasakii $-P$. pacificus above. The latter may further be subdivided into two or three subzones of Texanites amakusensis lower, the subzone of Protexanites bontanti shimizui-P. fukazawai and/or the subzone of Submortoniceras cf. condamyi in ascending order.

c) The zone of Texanites collignoni-T. quinquenodosus is correlated with the Lower Santonian, and the base of the Inoceramus amakusensis Zone is very close to or nearly at the same level as that of the zone of $T$. collignoni-T. quinquenodosus.

d) Taking the occurrences of Submortoniceras cf. condamyi, and Menabites mazenoti into consideration, the Platyceramus japonicus Zone should be assigned to the Lowest Campanian. This correlation is also supported by the occurrence of Globotruncana arca, provided that the first appearance of this species is recognized as a criterion of the base of the Campanian.

e) The Inoceramus uwajimensis-I. mihoensis Zone indicates the Coniacian Stage. Only the Inoceramus amakusensis Zone represents the Santonian Stage in Japan. The Platyceramus japonicus Zone and the subzone of Sphenoceramus sanrikuensis, S. cristatus and $I$. (C.) kanmerai represent the Lowest Campanian, whereas the Sphenoceramus orientalis Zone and S. schmidti Zone indicate the Lower Campanian.

(3) A large number of molluscan fossils were obtained from the study area. Palaeontological descriptions were given on some selected species of the inoceramid bivalves and the texanitine ammonoids. Among them, three new inoceramid species, i.e. Sphenoceramus cristatus, S. haboroensis and S. kiritachiensis were established on the specimens from the Lowest Campanian, and one texanitine ammonoid came from the upper part of the Santonian and the lowest part of the Campanian was described as a new genus and new species, Haboroceras haboroense.

Acknowledgments.-I am grateful to Professors Emeritus Kametoshi KANMERA and Tatsuro MATSUMOTO of Kyushu University for fruitful discussions and critical reading of the manuscript. I wish to thank Professor Juichi YANAGIDA and Associate Professor Yujiro OGAWA for their helpful criticism of the manuscript. I would like to thank Dr. K. PICKERING of University of Leicester for reading of the manuscript. I am much indebted to Dr. Masayuki NoDA, Oita City and Dr. Yasumitsu KANIE of Yokosuka City Museum for their 
help in the field work. I would like to thank Mr. Shigehiro UCHIDA, Iwamizawa City for his help in the field and for providing some samples. I am much indebted to Dr. Seijuro MAIYA of Laboratory of Japan Petroleum Exploration Co. Ltd. for identification of foraminiferal species and for his helpful advice.

\section{References}

Besairie, H. and Collignon, M. (1972) : Géologie de Madagascar I. Les terrain sédimentaires. Ann. Geol. Madagascar, (35), 1-463, pls. 1-89.

Birkelund, T., Hancock, J. M., Hart, M. B., Rawson, P. F., Remane, J., Robaszynski, F., Sch MID, F. and SURLYK, F. (1984) : Cretaceous stage boundaries-Proposals. Bull. Geol. Soc. Denmark, 33, 3-20.

Caldwell, W. G. E. and North, B. R. (1984): Cretaceous stage boundaries in the southern Interior Plains of Canada. Bull. Geol. Soc. Denmark, 33, 57-69.

Caron, M. (1985): Cretaceous planktic foraminifera. in Bolli, H. M., SAUNDERS, J. B. and Perch-Nielsen, K. (eds.) : Plankton stratigraphy. (4), 17-86, Cambridge Univ. Press.

Collignon, M. (1948a): Ammonites néocrétacées du Menabe (Madagascar). 1. Les Texanitidae. Ann. Geol. Serv. Mines Madagascar, (13), 49-107, pls. 7-20[1-14]. (1948b) : Ammonites néocrétacées du Menabe (Madagascar). 1. Les Texanitidae. Ann. Géol. Serv. Mines Madagascar, (14), 7-60, pls. 15-32.

(1966): Atlas de fossiles caracteristique de Madagascar (ammonites), (14), (Santonien), 134 p., pls. 455-513, Serv. Geol.

De Grossouvre, A. (1901) : Recherches sur la craie supérieure, 1, stratigraphie générale. Mem. Serv. Carte Geol. Det. Fr. vii+1013 p.

Douglas, R. C. (1969) : Upper Cretaceous planktonic foraminifera in northern California. Part 1-Systematics. Micropaleont., 15, (2), 151-209, pls. 1-11.

ERNST, G., SCHMID, F. and KLISCHIES, G. (1979) : Multistratigraphische Untersuchungen in der Oberkreide des Raumes Braunschweig-Hannover. Aspekte der Kreide Europas. IUGS Series A, (6), 11-46.

HATtoRI, Y. (1965): A find of ammonites from the Haranosawa Formation at the Chikubetsu Colliery in Hokkaido. Jour. Geol. Soc. Japan, 71, 149-151 (in Japanese).

Heinz, R. (1933) : Inoceramen von Madagascar und ihre Bedeutung für die KreideStratigraphie. Zeitschr. Deutsch. Geol. Gesellsch., 85, (4), 241-259, pls. 16-22.

Kase, T., Obata, I., Hanai, T., Kawakami, T., Yanagisawa, T. and Terui, K. (1984) : Geological age of the Sawamawari Formation in the Iwaizumi Graben, northern Kitakami Massif, Japan. Bull. Iwate Pref. Mus., (2), 164-177, pls. 1-4 (in Japanese with English abstract).

Kawakami, T., Futakami, M. and Obata, I. (1983): Ammonite specimens preserved in the Iwate Prefectural Museum, Part 1. Bull. Iwate Pref. Mus., (1), 15-26, pls. 4-5 (in Japanese with English abstract).

KENNEDY, J. W. (1983) : Ammonite faunas of the Coniacian, Santonian and Campanian Stages in the Aquitaine Basin. Geol. Mediter., 10, (3-4), 103-113.

- (1984a): Ammonite faunas and the 'standard zones' of the Cenomanian to Maastrichtian Stages in their type areas, with some proposals for the definition of the stage boundaries by ammonites. Bull. Geol. Soc. Denmark, 33, 147-161.

(1984b) : Systematic palaeontology and stratigraphic distribution of the Ammonite faunas of the French Coniacian. Spec. Publ. Palaeont., (31), $160 \mathrm{p}$.

and KLINGER, H. C. (1975): Cretaceous faunas from Zululand and Natal, South Africa. Introduction, Stratigraphy. Bull. Br. Mus. Natr. Hist. (Geol.), 25, 265315.

KLINGER, H. C. and KENNEDY, J. W. (1980): Cretaceous faunas from Zululand and Natal, South Africa. The ammonites subfamily Texanitinae Collignon, 1948. Ann. S. Afr. Mus., 80, 1-357. 
and - (1981): The Umzamba Formation at its type section, Umzamba Estuary (Pondoland, Transkei), the ammonite content and palaeogeographical distribution. Ann. S. Afr. Mus., 81, (6), 207-222.

MAIYA, S. (1985) : Cretaceous foraminiferal zonations of Japan and their international correlation. Mem. Geol. Soc. Japan, (26), 86-99 (in Japanese with English abstract).

and TAKAYANAGI, Y. (1977): Cretaceous foraminiferal biostratigraphy of Hokkaido. Palaeont. Soc. Japan, Spec. Pap., (21), 41-62.

MATsumoto, T. (1942a) : On the stratigraphic classification of the Cretaceous deposits in the central zone of Hokkaido and Saghalien. Jour. Geol. Soc. Japan, 49, 92-111 (in Japanese).

$(1942 b)$ : Fundamentals in the Cretaceous stratigraphy of Japan. Part I. Mem. Fac. Sci., Kyushu Univ., [D], 1, (1), 129-280, pls. 5-20.

(1943): Fundamentals in the Cretaceous stratigraphy of Japan. Parts II and III. Mem. Fac. Sci., Kyushu Univ., [D], 2, (1), 129-280, pls. 5-20.

(1959) : Upper Cretaceous ammonites of California. Part II. Mem. Fac. Sci., Kyushu Univ. [D], Spec. Vol. 1, 172 p., pls. 1-41.

(1960): Upper Cretaceous ammonites of California. Part III. Mem. Fac. Sci., Kyushu Univ. [D], Spec. Vol. 2, 204 p., pls. 1-2.

(1965) : A monograph of the Collignoniceratidae from Hokkaido, part II. Mem. Fac. Sci., Kyushu Univ., [D], 16, 209-243, pls. 36-43.

(1970): A monograph of the Collignoniceratidae from Hokkaido, part IV. Mem. Fac. Sci., Kyushu Univ., [D], 20, 225-304, pls. 30-47.

(1977): Zonal correlation of the Upper Cretaceous in Japan. Palaeont. Soc. Japan, Spec. Pap., (21), 63-74.

(1982) : Upper Cretaceous ammonites from the Monobe area, Shikoku. Palaeont. Soc. Japan, Spec. Pap., (25), 31-52, pls. 1-7.

- and HARAgUCHI, Y. (1978): A new texanitine ammonite from Hokkaido. Trans. Proc. Palaeont. Soc. Japan, N.S., (110), 306-318, pl. 42.

and Hirano, H. (1976): Colour patterns in some Cretaceous ammonites from Hokkaido. Trans. Proc. Palaeont. Soc. Japan, N.S., (102), 334-343, pl. 35.

, MaIYA, S. and NodA, M. (in press): Correlation of inoceramids and Foraminifera in the Upper Cretaceous of the Kikume-zawa, Hokkaido. Kaseki (Fossils) (in Japanese).

- and Mryauchi, T. (1984): Some Campanian ammonites from the Soya area. in Matsumoto, T.: Some ammonites from the Campanian (Upper Cretaceous) of northern Hokkaido. Palaeont. Soc. Japan, Spec. Pap., (27), 33-76, pls. 10-31.

, Muramoto, K., Hirano, H. and Takahashi, T. (1981) : Some Coniacian ammonites from Hokkaido. Trans. Proc. Palaeont. Soc. Japan, N.S., (121), 51-73, pls. $6-8$.

, NoDA, M. and KozAI, T. (1982): Upper Cretaceous inoceramids from the Monobe area, Shikoku. Palaeont. Soc. Japan, Spec. Pap., (25), 53-68, pls. 8-11.

and NodA, M. (1985): A new inoceramid (Bivalvia) species from the Upper Campanian (Cretaceous) of Hokkaido. Proc. Japan Acad., 61, [B], 9-11.

and OKadA, H. (1973): Saku Formation of the Yezo geosyncline. Sci. Rep. Dept. Geol. Kyushu Univ., 11, (2), 275-319 (in Japanese with English abstract).

and Sugryama, R. (1985): A new inoceramid (Bivalvia) species from the Upper Cretaceous of northwest Japan. Proc. Japan Acad., 61, [B], 106-108.

and (1986): Note on an inoceramid species from the Upper Cretaceous Taneichi Formation of Iwate Prefecture. Bull. Iwate Pref. Mus., (4), 17-26, pl. 3 (in Japanese with English abstract).

and TAKahashi, T. (1986): A record of Menabites (Ammonoidea) from Hokkaido. Proc. Japan Acad., 62, [B], 79-81.

and TASHIRo, M. (1982): Concluding remarks on the multidisciplinary research in the Monobe area, Shikoku. Palaeont. Soc. Japan, Spec. Pap., (25), 117-123. 
and UEDA, Y. (1962) : Palaeontological notes (Appendix to the type Himenoura Group by Yoshiro UEDA). Mem. Fac. Sci., Kyushu Univ., [D], 12, 162-174, pls. 22-27.

Matsuno, K. and Kino, Y. (1960): Chikubetsu-tanko. Expl. Text. Geol. Map. Japan, scale 1:50000, Asahikawa-30, 43+6 p.

NaIdin, D. P. (1979): Vergleichende Stratigraphie der Oberen Kreide der Russischien Tafel und West-Europas. Aspekte der Kriede Europas. IUGS Series A, (6), 497-510.

Obradovich, J. D. and CobBan, W. A. (1975): A time-scale for late Cretaceous of the western interior of North America. Geol. Assoc. Canada, Spec. Pap., 13, 31-45.

OKadA, H. and Matsumoto, T. (1969): Cyclic sedimentation in a part of the Cretaceous sequence of the Yezo Geosyncline, Hokkaido. Jour. Geol. Soc. Japan, 75, 311-328 (in Japanese with English abstract).

OKamura, M., Nakaseko, K. and Nakano, K. (1982) : Radiolarians from the Kajisako Formation, Monobe area, Shikoku. Palaeont. Soc. Japan, Spec. Pap., (25), 93-102, pls. 15-18.

PERgament, M. A. (1974) : Biostratigraphy and Inoceramus of Senonian (SantonianMaestrichtian) of the USSR Pacific Regions. Trans., 260, 267 p. (in Russian). (1978) : Upper Cretaceous stratigraphy and Inoceramus of the northern hemisphere. Trans., 322, 214 p. (in Russian).

Pozaryska, K. and PERYT, D. (1979) : The Late Cretaceous and Early Paleocene foraminiferal "transitional province" in Poland. Aspekte der Kreide Europas. IUGS Series A, (6), 293-303.

Robaszynski, F., Caron, M., Gonzalez Donoso, J. M. and Wonders, A. A. H. (1984) : Atlas of Late Cretaceous grobotruncanids. Rev. Micropaleont., 26, (3-4), 145305 , pls. 1-54.

SALAJ, J. (1984) : Boundaries of Upper Cretaceous hypostratotypes at the profile Djebel Fguira Salah, Tunisia. Bull. Geol. Soc. Denmark, 33, 199-201.

- and GaŚPARIKová, V. (1979): Microbiostratigraphy of the Upper Cretaceous of the West Carpathians based in Foraminifers and Nannofossils and the question of relations and migrations of boreal and Tethyan elements. Aspekte der Kreide Europas. IUGS Series A, (6), 279-292.

SASA, Y. (1932) : Geology of Kudi district, Iwate Prefecture. Jour. Geol. Soc. Japan, 39, (466), 401-430 (in Japanese).

Schulz, M.-G., ERNst, G., ERNSt, H. and Schmid, F. (1984) : Coniacian to Maastrichtian stage boundaries in the standard section for the Upper Cretaceous white chalk of NW Germany (Lagerdorf-Kronsmoor-Hemmoor): Definitions and proposals. Bull. Geol. Soc. Denmark, 33, 203-215.

Seitz, O. (1961) : Die Inoceramen des Santon von Nordwestdeutschland. Beih. Geol. Jb., 46, 1-186, pls. 1-15.

(1965) : Die Inoceramen des Santon und Unter-Campan von Nordwestdeutschland. II. Teil. Beih. Geol. Jb., 69, 1-194, pls. 1-26.

(1967): Die Inoceramen des Santon und Unter-Campan von Nordwestdeutschland. III. Teil. Beih. Geol. Jb., 75, 1-171, pls. 1-27.

Takayanagr, Y. and Matsumoto, T. (1981): Recent advances in the Cretaceous biostratigraphy of Japan by coordinating mega- and micro-fossils. Rec. Prog. Natr. Sci. Japan, 6, 125-138.

—, YasUdA, H. and Shimamura, K. (1982) : Notes on Upper Cretaceous planktonic Foraminifera from the Kajisako Formation, Kochi Prefecture, Japan. Palaeont. Soc. Japan, Spec. Pap., (25), 93-116, pl. 19-23.

Tanabe, K., Hirano, H., Matsumoto, T. and Miyata, Y. (1977): Stratigraphy of the Upper Cretaceous deposits in the Obira area, northwestern Hokkaido. Sci. Rep. Dept. Geol. Kyushu Univ., 12, (3), 181-202 (in Japanese with English abstract).

TANAKA, K. (1963): A study on the Cretaceous sedimentation in Hokkaido, Japan. Rep. Geol. Surv. Japan, (197), 1-122. 
TASHIRo, M. and KozAI, T. (1982) : Bivalve fossils from the Upper Cretaceous of the Monobe area, Shikoku. Palaeont. Soc. Japan, Spec. Pap., (25), 69-92, pls. 12-14.

Toshimitsu, S. (1985) : Biostratigraphy and depositional facies of the Cretaceous in the Upper reaches of the Haboro River, Hokkaido. Jour. Geol. Soc. Japan, 91, 599-618 (in Japanese with English abstract).

(1986): A new inoceramid (Bivalvia) species from the Upper Cretaceous of Hokkaido. Proc. Japan Acad., 62, [B], 227-230.

and MAIYA, S. (1986): Integrated inoceramid-foraminiferal biostratigraphy of the Upper Cretaceous of northwestern Hokkaido, Japan. Cret. Research, 7, 307-326.

TröGER, K.-A. (1966): Biostratigraphie der Inoceramen und einiger ausgewählter Ammoniten, Belemniten und Echinoidermaten des Unter-Coniac bis Unter-Campan in der DDR. Abh. Zentr. Geol. Inst, 5, 84-91.

Unda, Y., Matsumoto, T. and Akatsu, K. (1962): The Cretaceous deposits in the Chikubetsu area, Hokkaido. Sci. Rep. Dept. Geol. Kyushu Univ., 6, (1), 15-32 (in Japanese with English abstract).

WARD, P. D. (1978): Revisions to the stratigraphy and biochronology of the Upper Cretaceous Nanaimo Group, British Columbia and Washington State. Canad. Jour. Earth Sci., 15, (3), 405-423.

YABE, H. (1902): Note on the three Upper Cretaceous ammonites from Japan, outside of Hokkaido. Jour. Geol. Soc. Tokyo (Japan), 9, 5-10 (English pages), pl. 10.

Young, K. (1963) : Upper Cretaceous ammonites from the Gulf coast of the United States. Univ. Texas Publ., (6304), 1-373. 


\section{Appendix}

Figures (7-27) and Tables (1-8) 


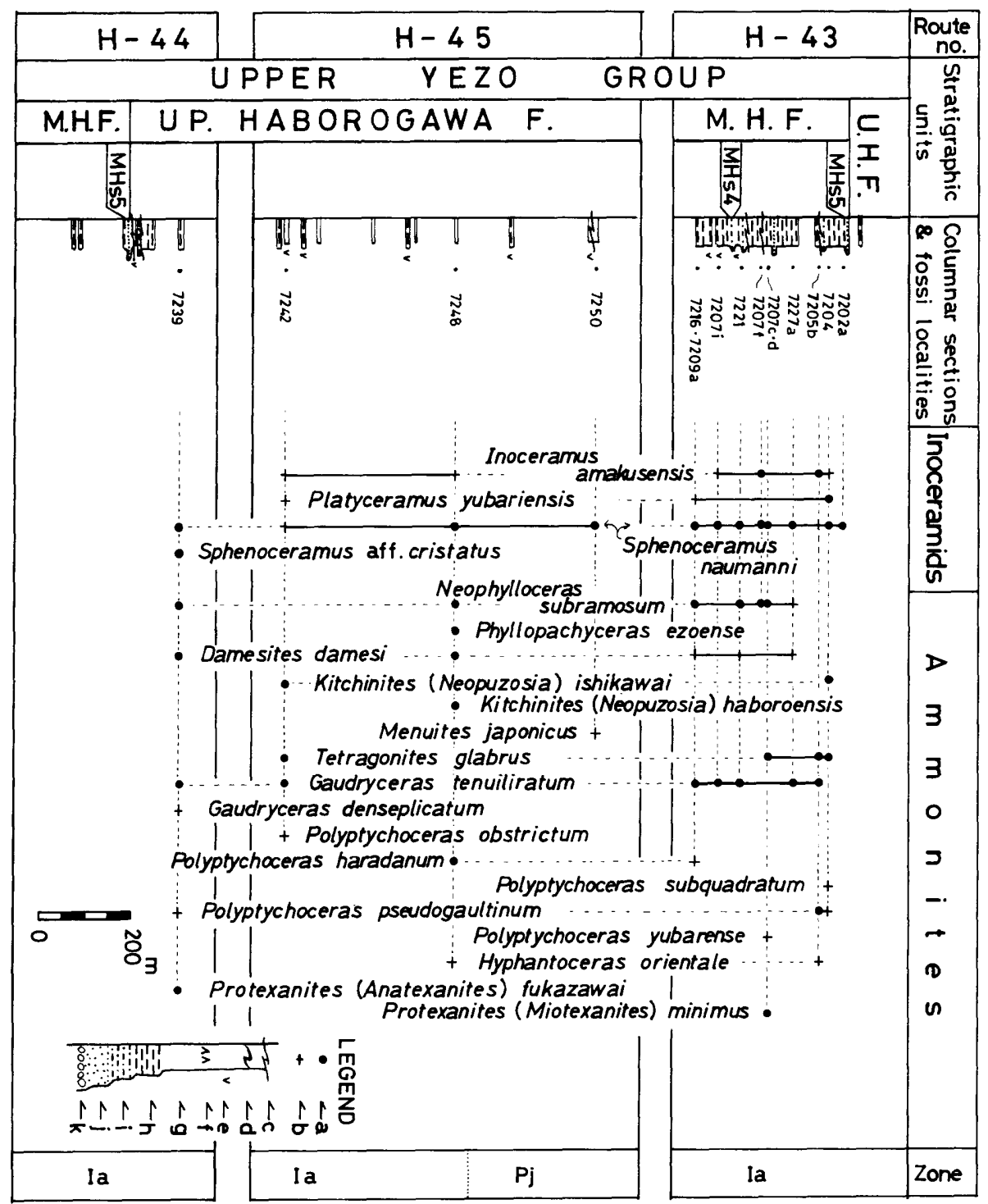

Fig. 7. Biostratigraphic successions of the Upper Yezo Group along the Pisshirizawa in the Haboro area, Hokkaido. Route numbers are shown in Figs. 2, 3. Put prefix $\mathrm{RH}$ on each locality number.

Ia: Inoceramus amakusensis Zone, $\mathrm{Pj}$ : Platyceramus japonicus Zone legend; a : point of occurrence of fossils, $b$ : point of occurrence of imcomplete fossil specimens to be compared to the noted species, c: fault, d: slump bed, $\mathrm{e}$ : tuff or tuffite, $\mathrm{f}$ : fine-grained volcanic debris bed, $\mathrm{g}$ : claystone, $\mathrm{h}$ : siltstone, $\mathrm{i}$ : alternation of sandstone and mudstone, $\mathrm{j}$ : sandstone, $\mathrm{k}$ : conglomerate 


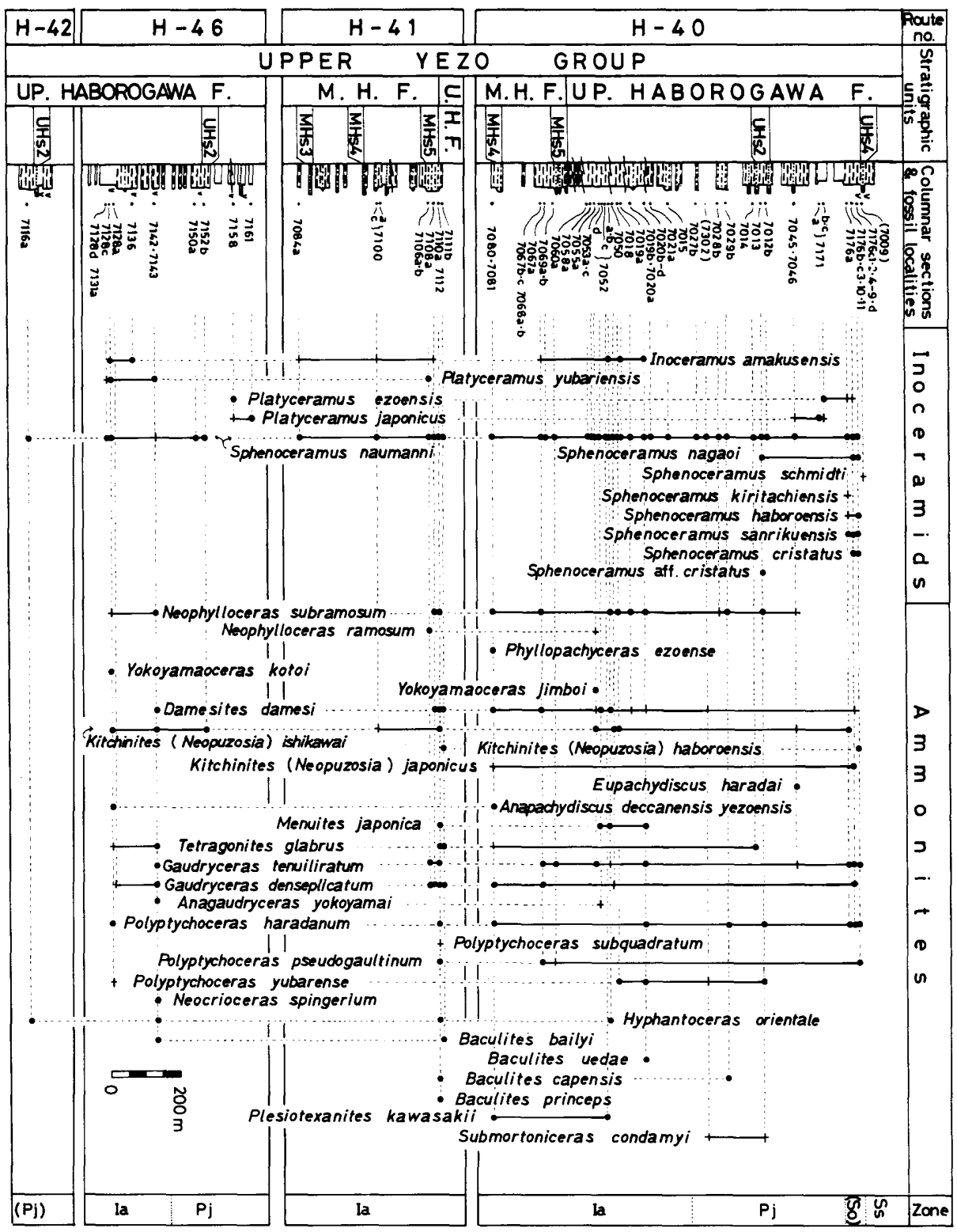

Fig. 8. Biostratigraphic successions of the Upper Yezo Group along the Detofutamata-gawa in the Haboro area, Hokkaido. Route numbers are shown in Figs. 2, 3. Numbers in parentheses show inferred horizon from the neibouring route. Put prefix $\mathrm{RH}$ on each loc. no.

Ia: Inoceramus amakusensis Zone, $\mathrm{Pj}$ : Platyceramus japonicus Zone, So:

Sphenoceramus orientalis Zone, Ss: S. schmidti Zone 


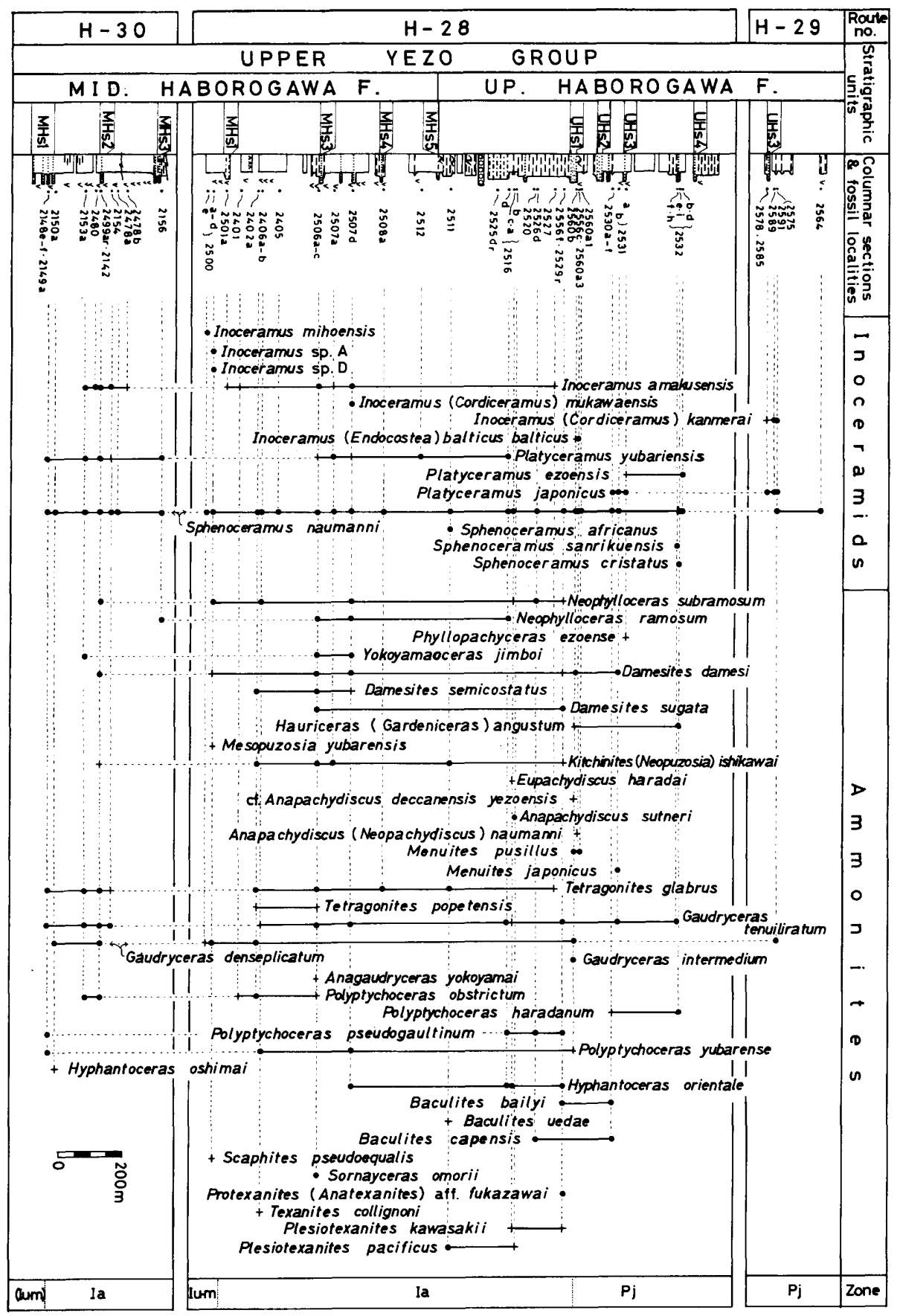

Fig. 9. Biostratigraphic successions of the Upper Yezo Group along the Nakanofutamata-gawa in the Haboro area, Hokkaido. Route numbers are shown in Figs. 2, 3. Put prefix RH on each loc. no.

Iu-m: Inoceramus uwajimensis-I. mihoensis Zone, Ia: Inoceramus amakusensis Zone, $\mathrm{Pj}$ : Platyceramus japonicus Zone 


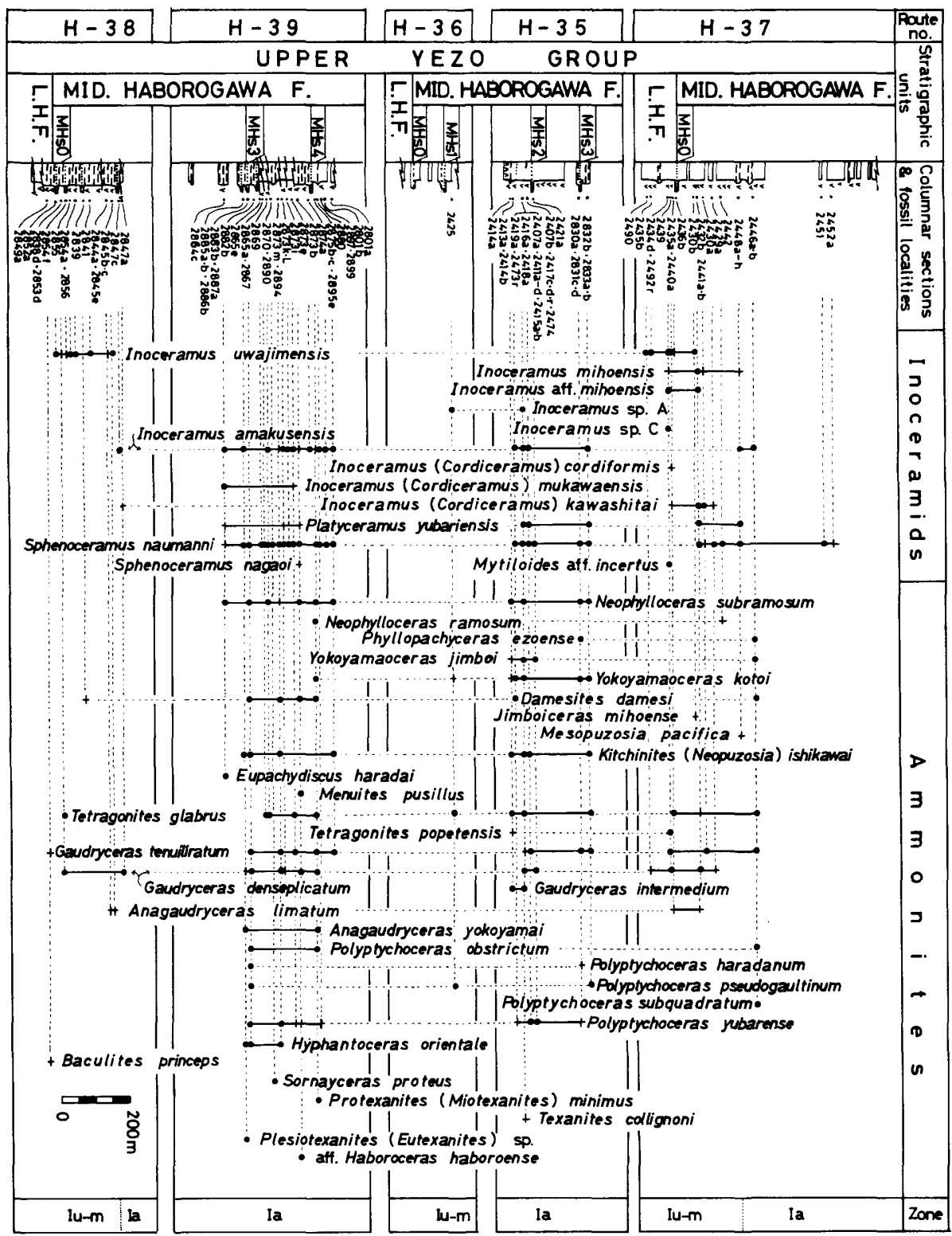

Fig. 10. Biostratigraphic successions of the Upper Yezo Group along the Machiyoi-zawa and Shimizu-zawa in the Haboro area, Hokkaido. Route numbers are shown in Figs. 2, 3. Put prefix $\mathrm{RH}$ on each loc. no. Iu-m: Inoceramus uwajimensis-I. mihoensis Zone, Ia: I. amakusensis Zone 


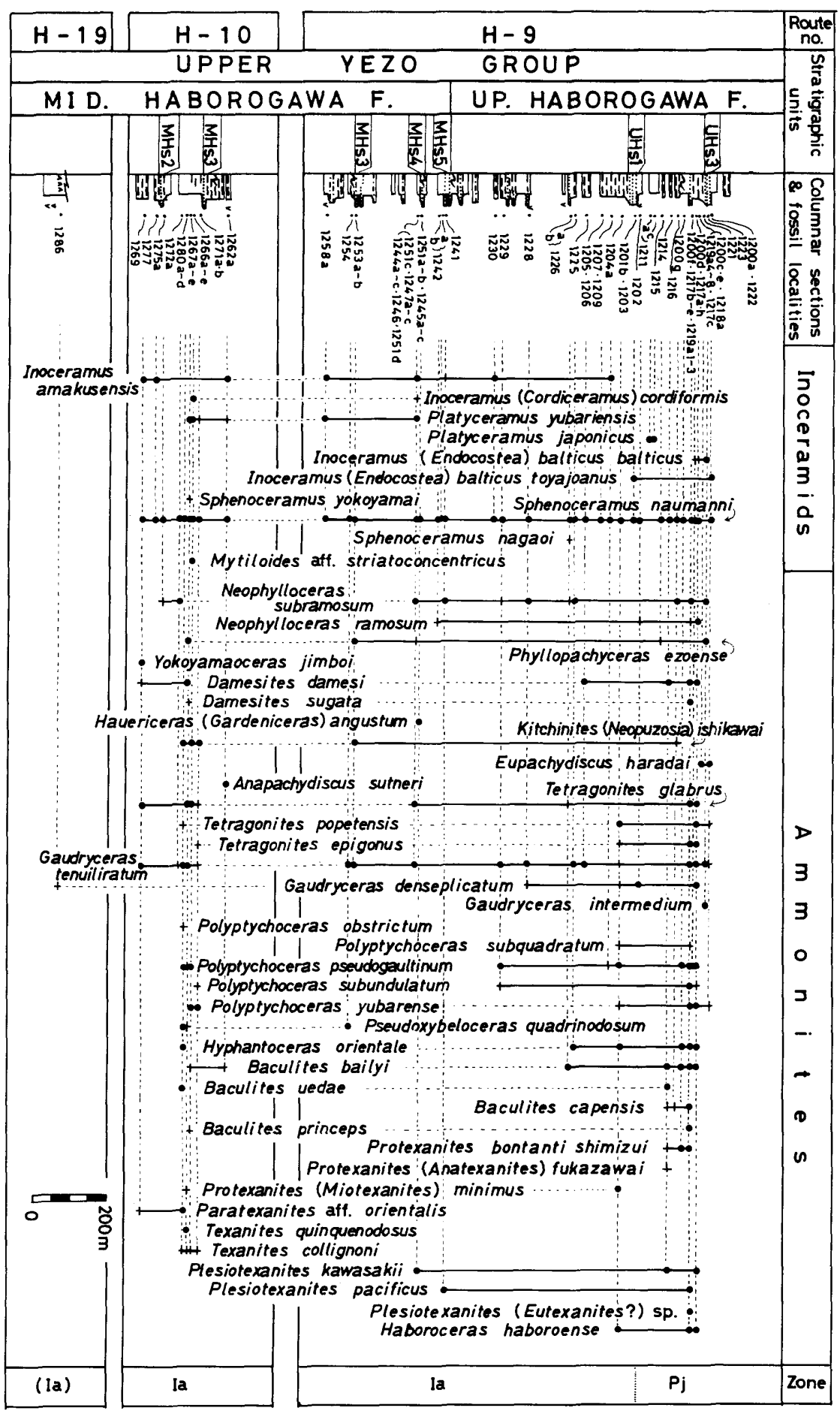

Fig. 11. Biostratigraphic successions of the Upper Yezo Group along the Sakasa-gawa in the Haboro area, Hokkaido. Route numbers are shown in Figs. 2, 3. Put prefix $\mathrm{RH}$ on each loc. no.

$\mathrm{Ia}$ : Inoceramus amakusensis Zone, $\mathrm{Pj}$ : Platyceramus japonicus Zone 


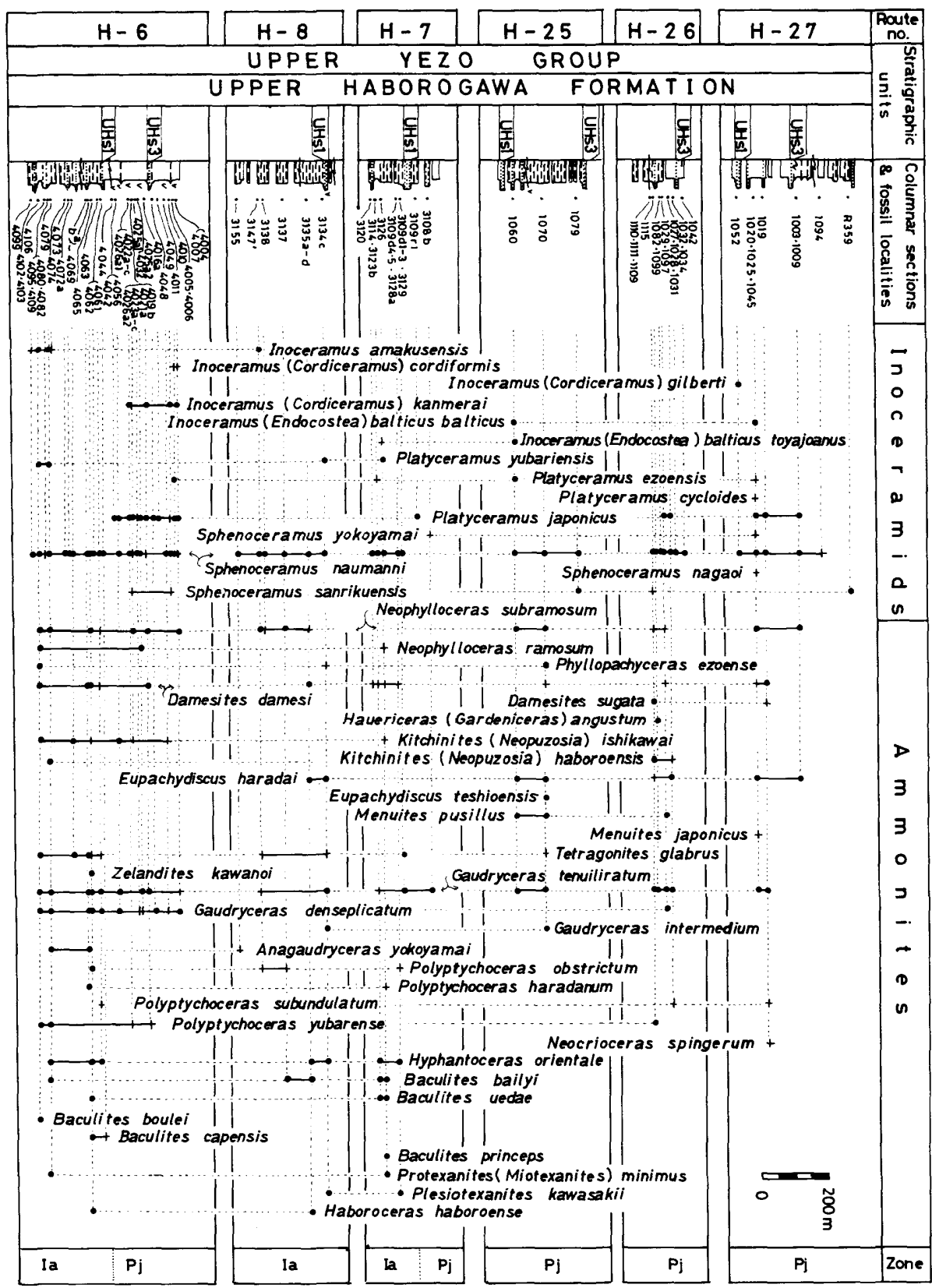

Fig. 12. Biostratigraphic successions of the Upper Yezo Group along the Migino-sawa, Kotodo-zawa and Otodo-zawa in the Haboro area, Hokkaido. Route numbers are shown in Figs. 2, 3. Put prefix RH on each loc. no. Ia: Inoceramus amakusensis $\mathrm{Zone}, \mathrm{Pj}$ : Platyceramus japonicus $\mathrm{Zone}$ 


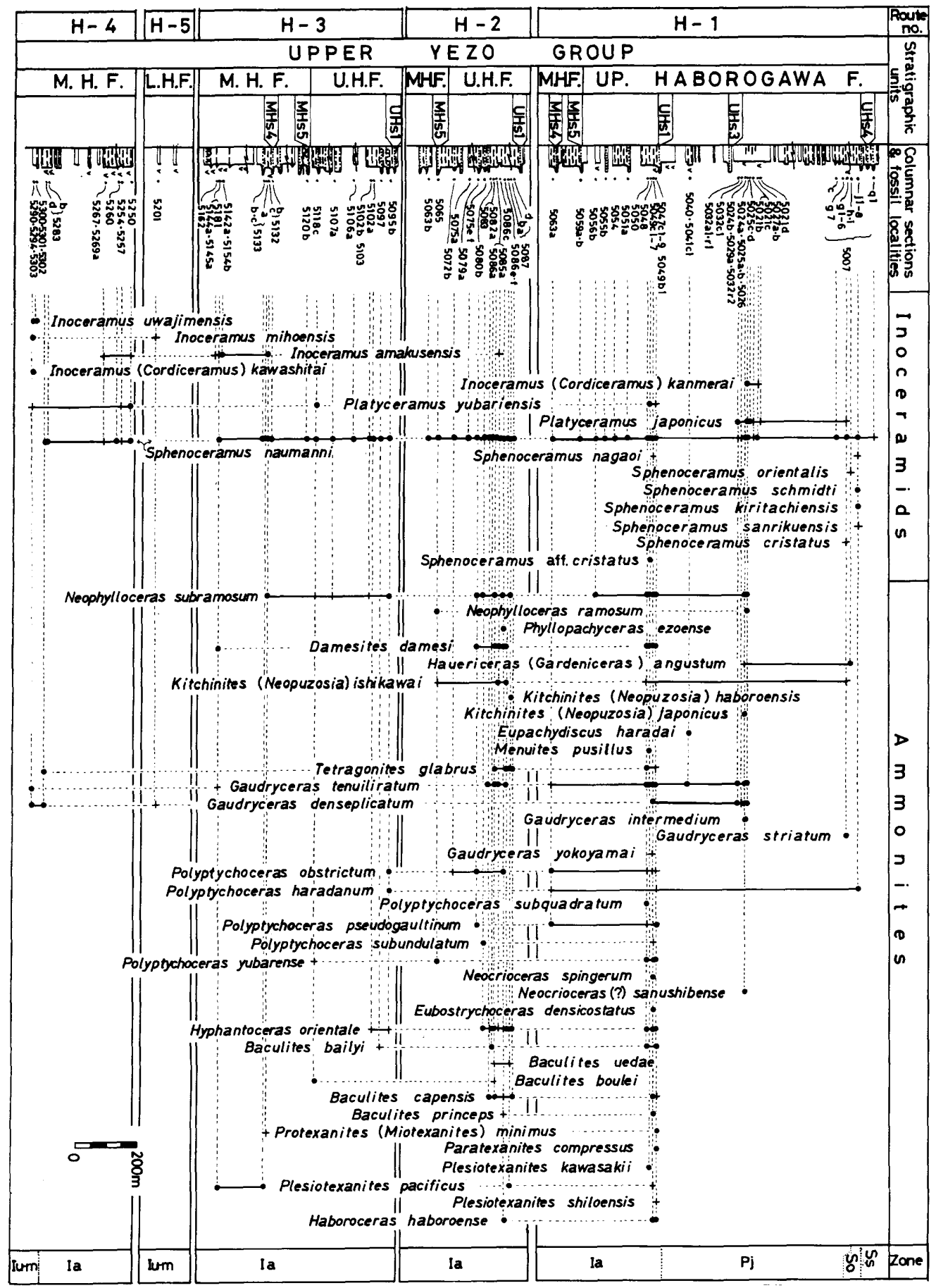

Fig. 13. Biostratigraphic successions of the Upper Yezo Group along the Chimei-zawa in the Haboro area, Hokkaido. Route numbers are shown in Figs. 2, 3. Put prefix $\mathrm{RH}$ on each loc. no.

Iu-m: Inoceramus uwajimensis-I. mihoensis Zone, Ia: Inoceramus amakusensis Zone, $\mathrm{Pj}$ : Platyceramus japonicus Zone, So: Sphenoceramus orientalis, Ss: S. schmidti Zone 


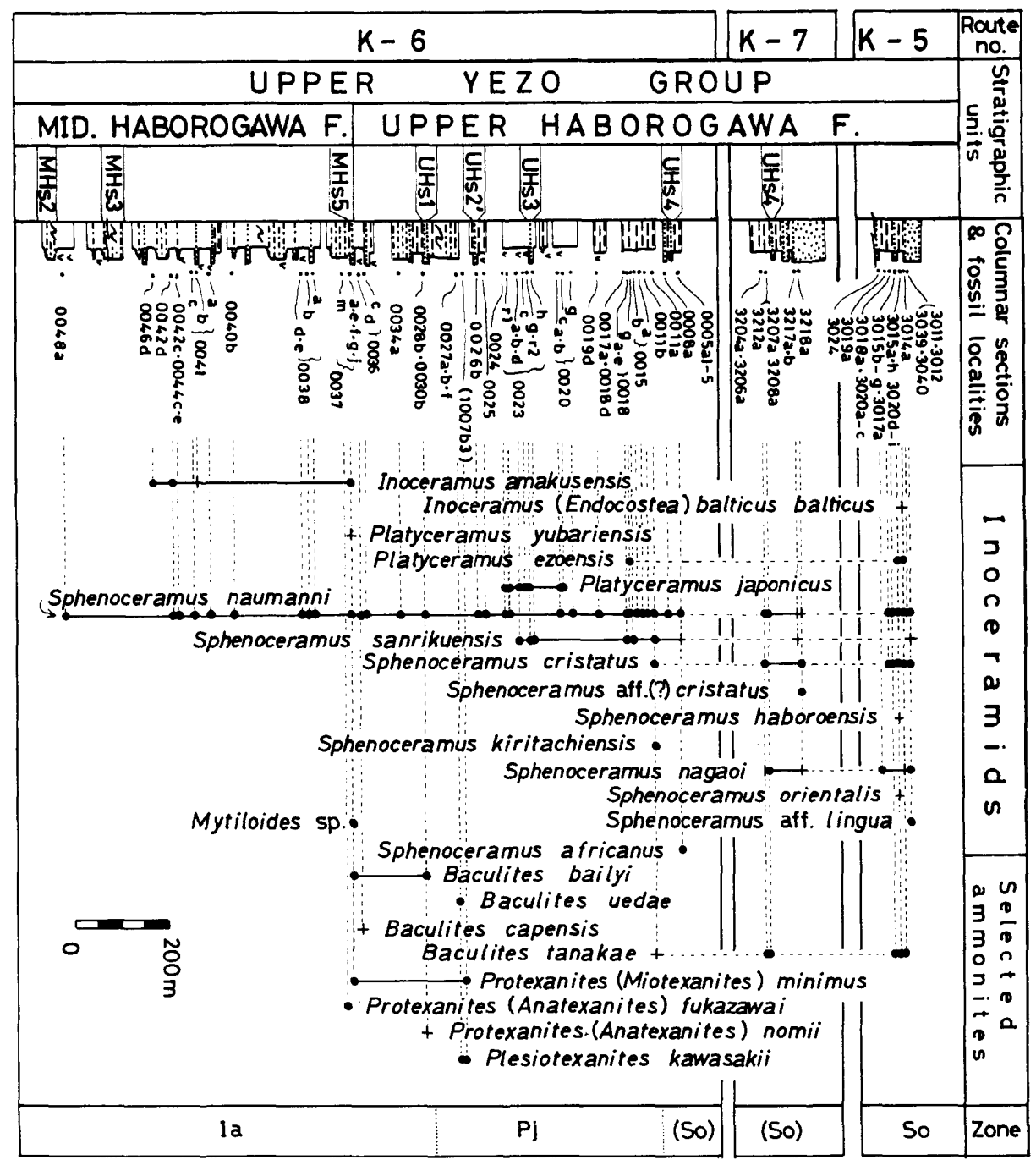

Fig. 14a. Biostratigraphic successions of the Upper Yezo Group along the Kotanbetsu River, Hokkaido. Route numbers are shown in Figs. 2, 3. Put prefix RK on each loc. no.

$\mathrm{Ia}$ : Inoceramus amakusensis Zone $\mathrm{Pj}$ : Platyceramus japonicus Zone, So: Sphenoceramus orientalis, Ss: S. schmidti Zone 


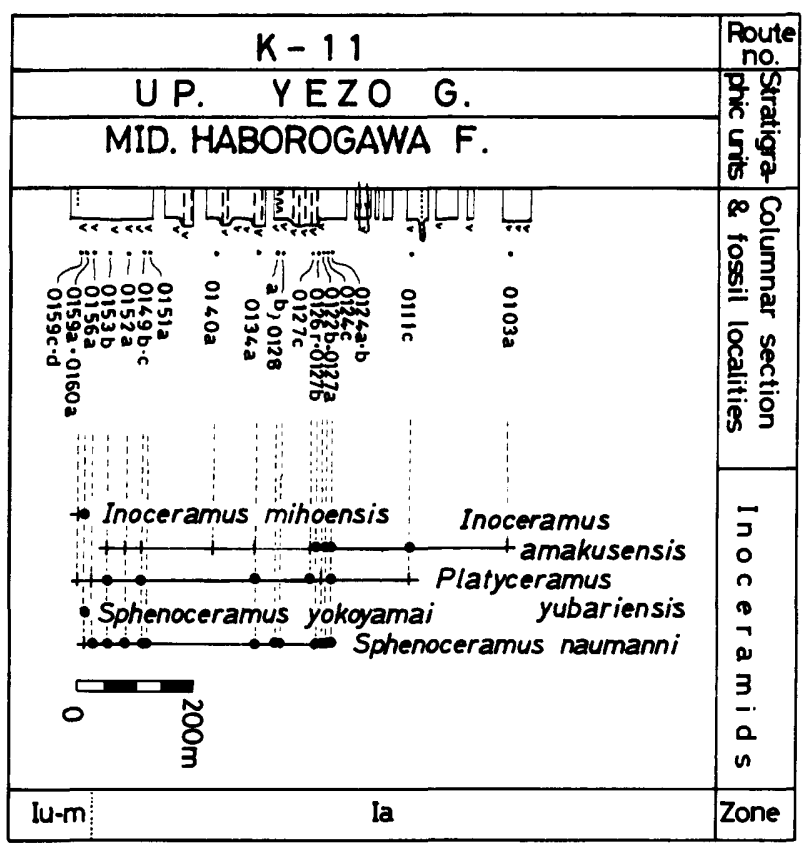

Fig. 14b. Biostratigraphic successions of the Upper Yezo Group along the Futamata-zawa in the Kotanbetsu area, Hokkaido. Route number is shown in Figs. 2, 3. Put prefix RK on each loc. no.

Iu-m: Inoceramus uwajimensis-I. mihoensis Zone, Ia: Inoceramus amakusensis Zone 


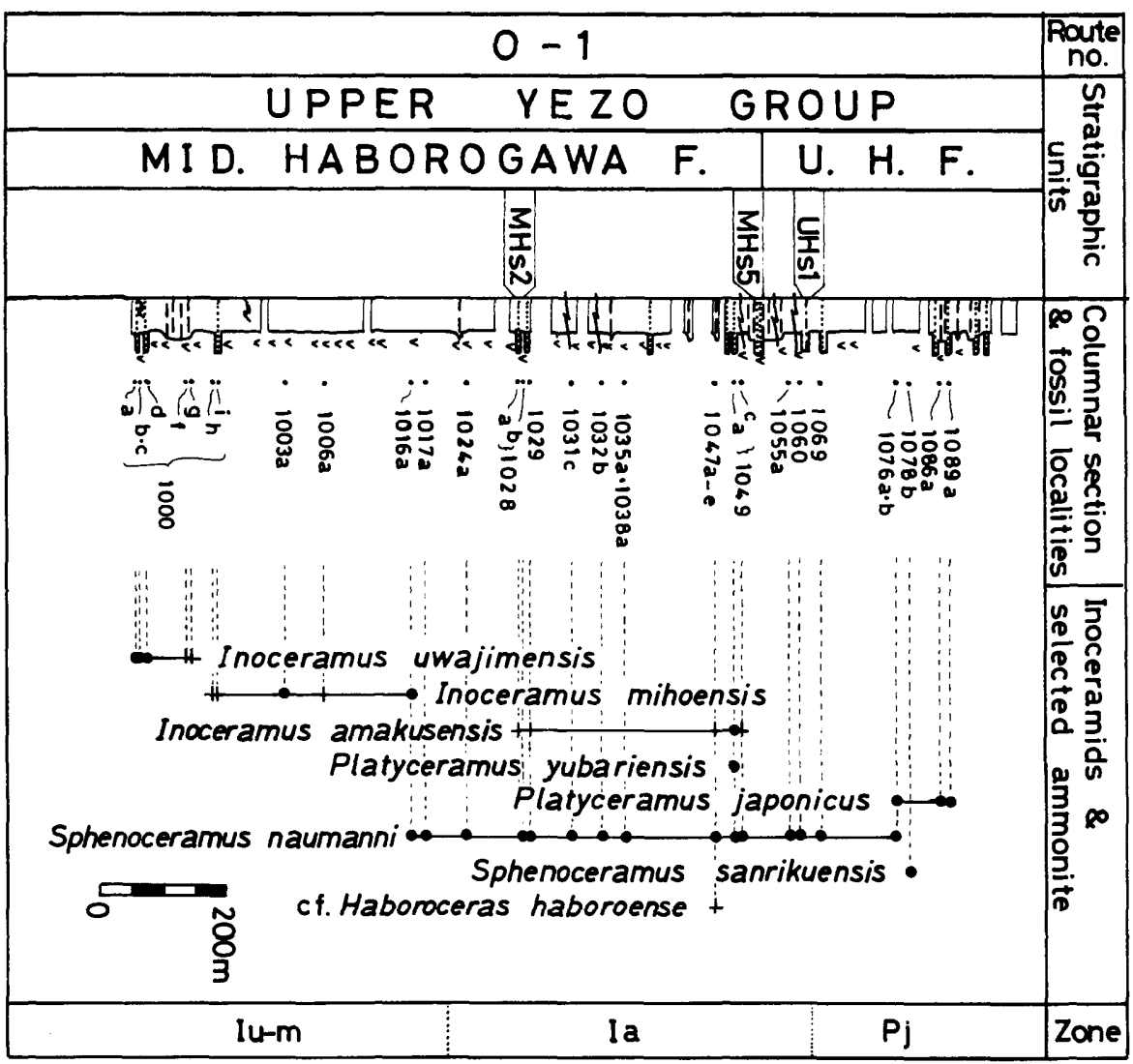

Fig. 15a. Biostratigraphic successions of the Upper Yezo Group along the Jugosen-zawa in the Obira area, Hokkaido. Route number is shown in Figs. 2, 3. Put prefix RO on each loc. no.

Iu-m: Inoceramus uwajimensis-I. mihoensis Zone, Ia: Inoceramus amakusensis Zone, $\mathrm{Pj}$ : Platyceramus japonicus Zone 


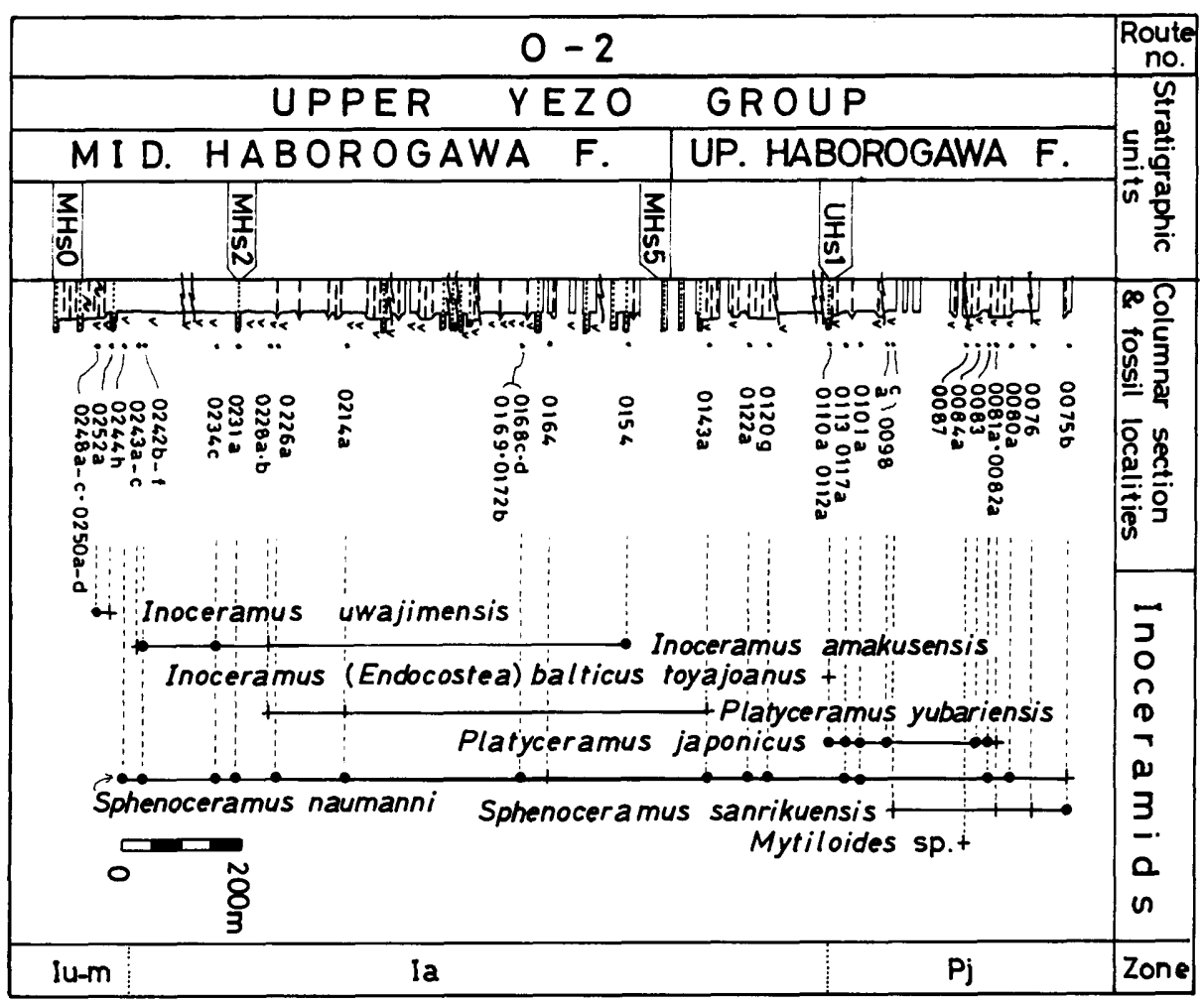

Fig. 15b. Biostratigraphic successions of the Upper Yezo Group along the Akano-sawa in the Obira area, Hokkaido. Route number is shown in Figs. 2, 3. Put prefix RO on each loc. no.

Iu-m: Inoceramus uwajimensis-I. mihoensis Zone, Ia: Inoceramus amakusensis Zone, $\mathrm{Pj}$ : Platyceramus japonicus Zone 


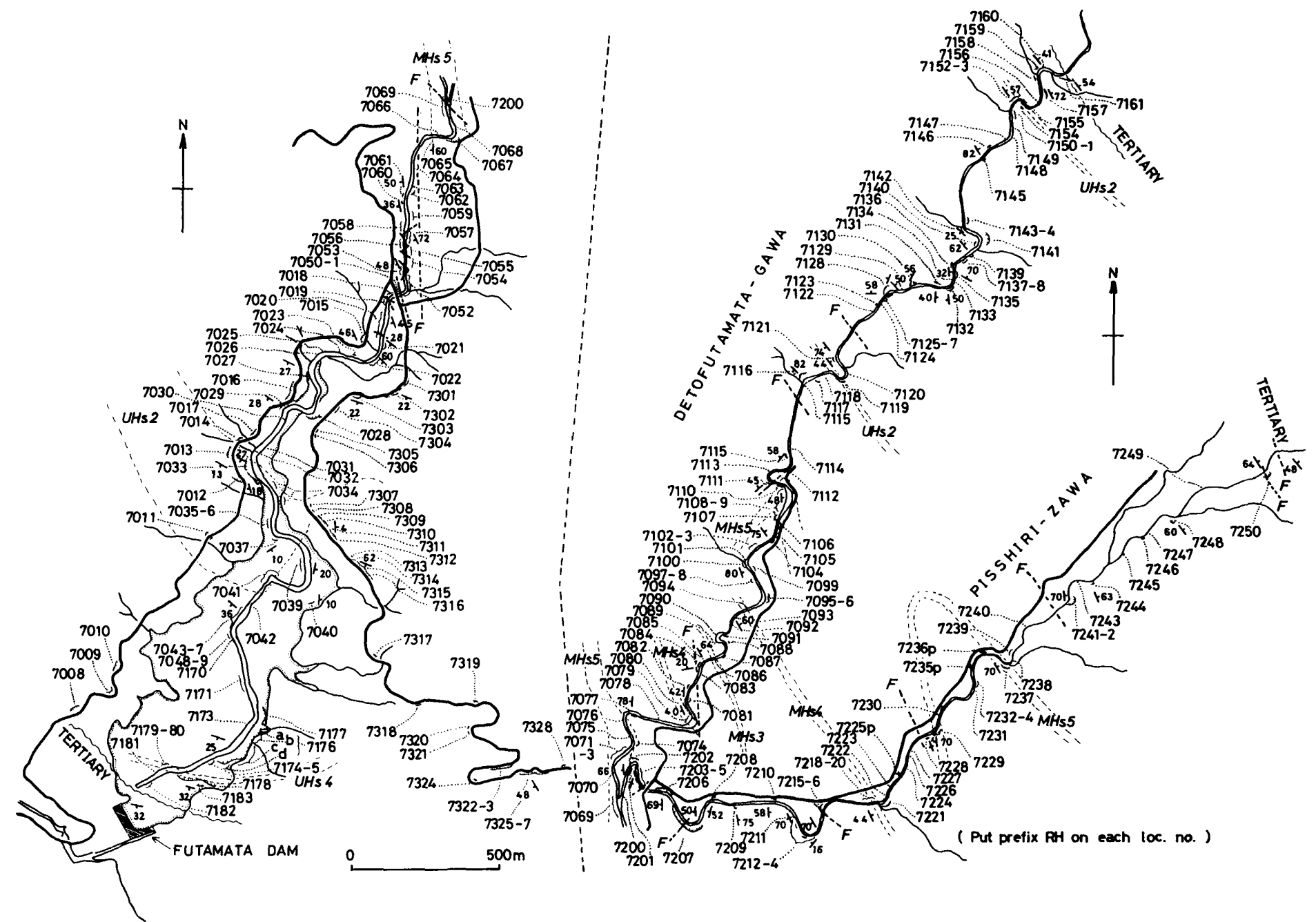

Fig. 16. Route map along the Detofutamata-gawa in the Haboro area. $F$ : fault 


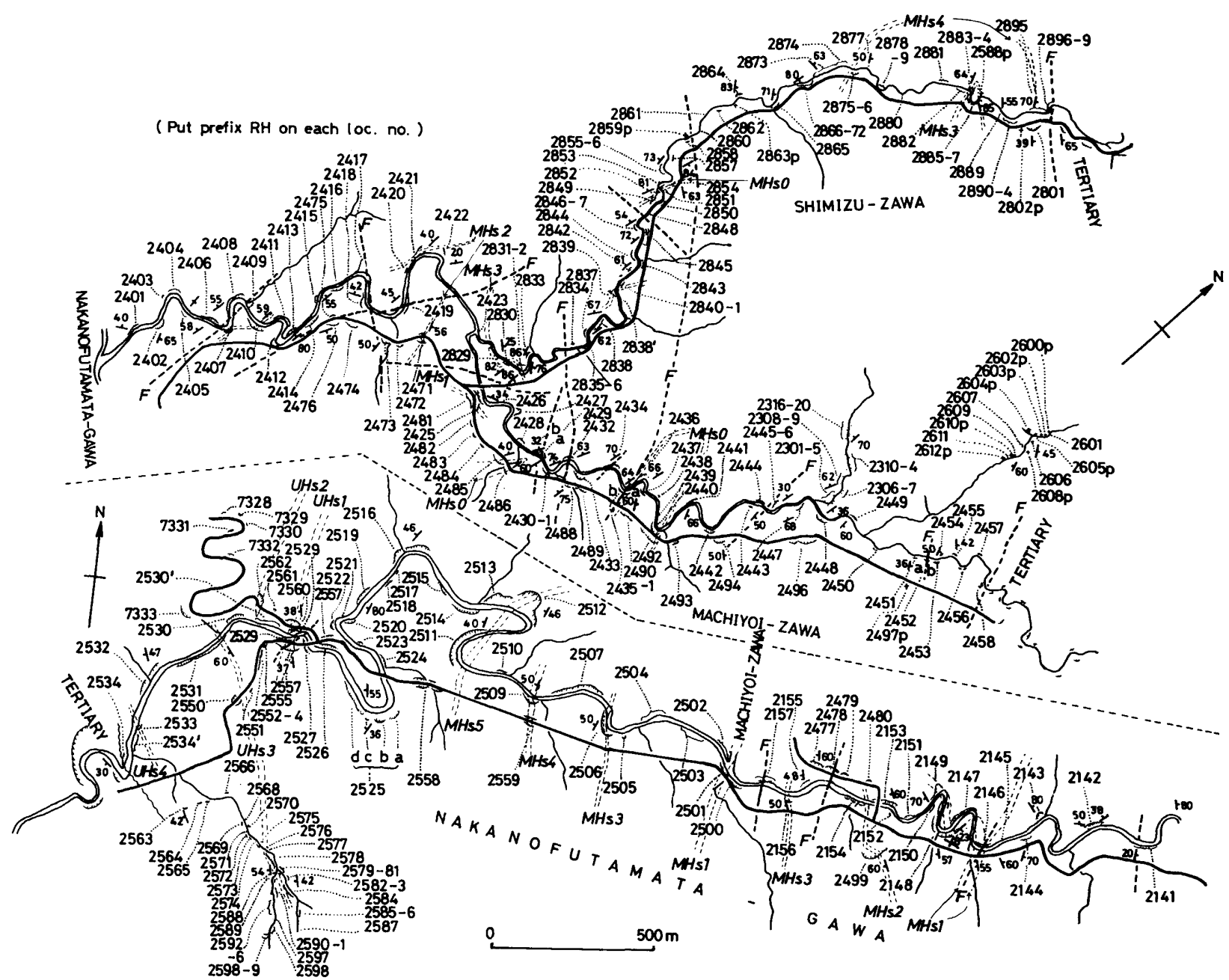

Fig. 17. Route map along the Nakanofutamata-gawa in the Haboro area. 


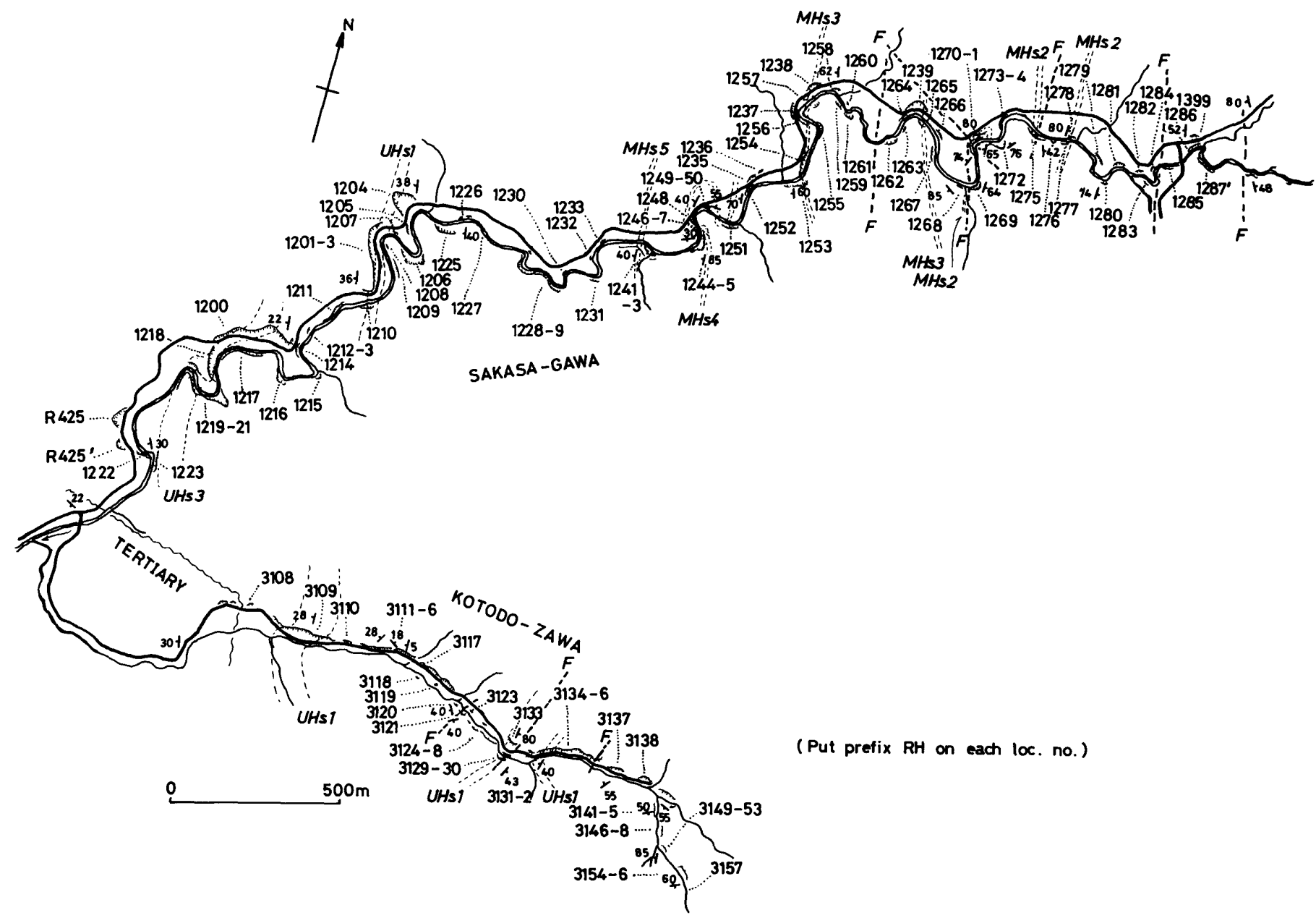

Fig. 18. Route map along the Sakasa-gawa in the Haboro area. 


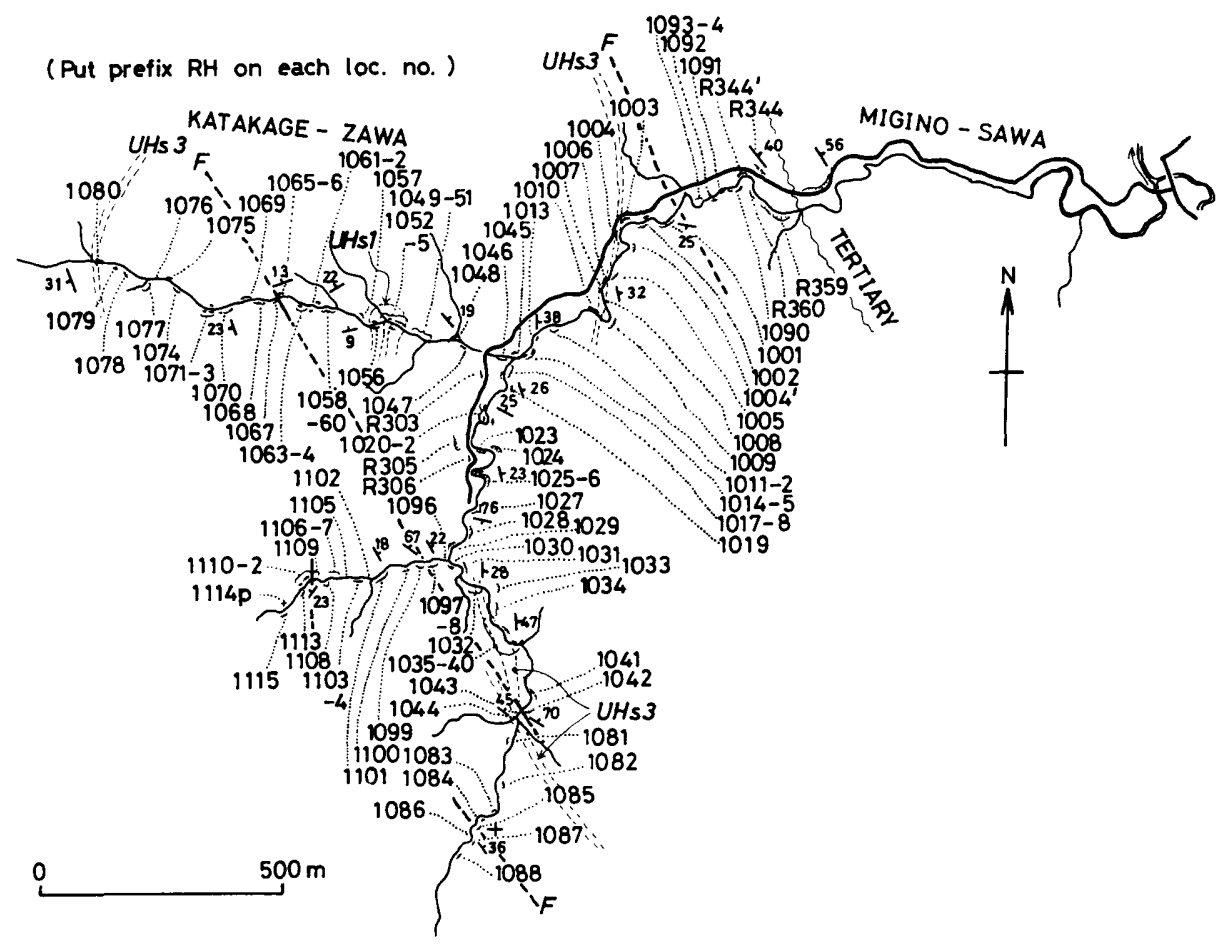

Fig. 19. Route map along the Migino-sawa in the Haboro area.

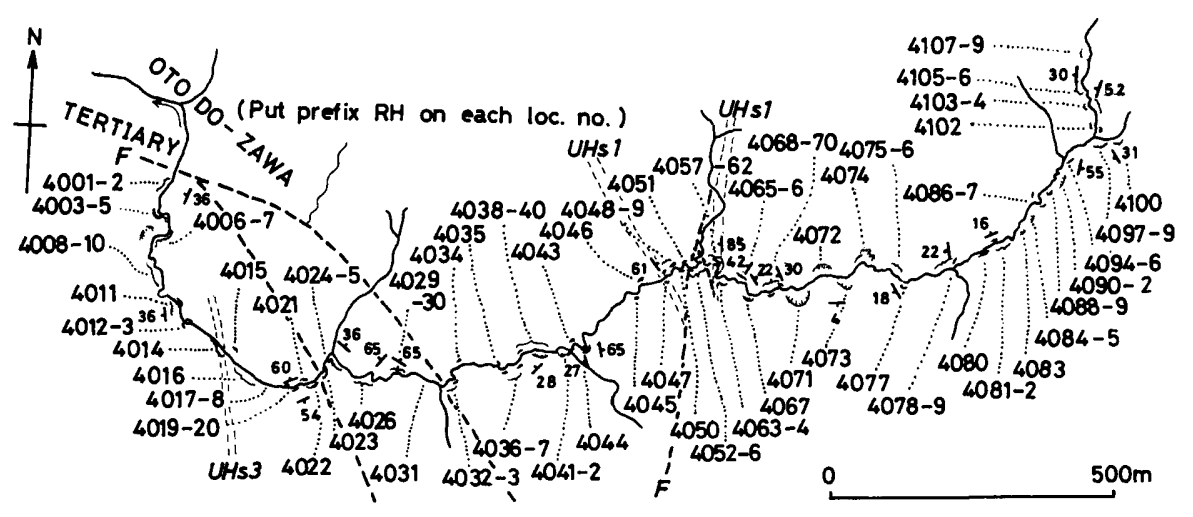

Fig. 20. Route map along the Otodo-zawa in the Haboro area. 


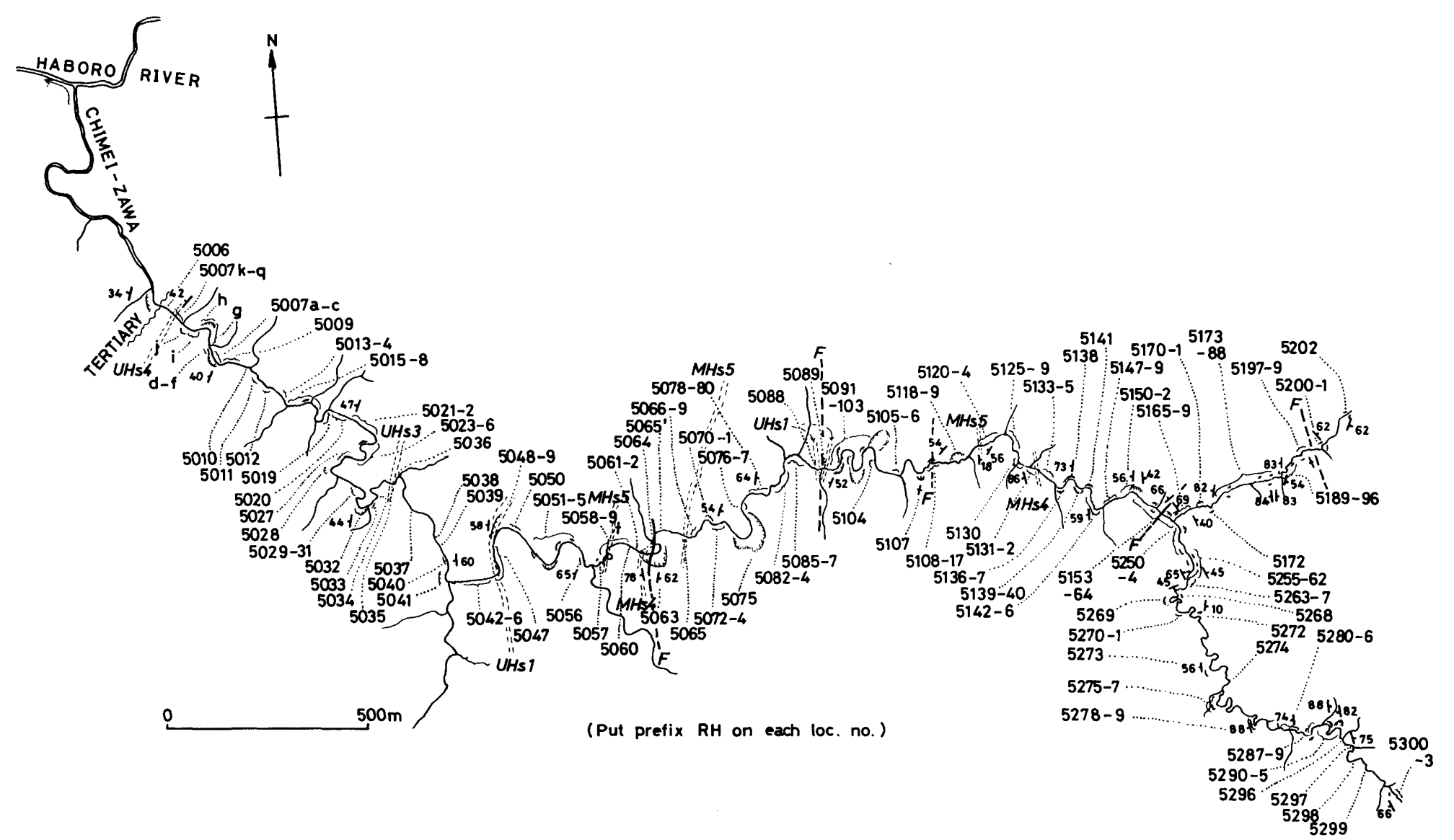

Fig. 21. Route map along the Chimei-zawa in the Haboro area. 


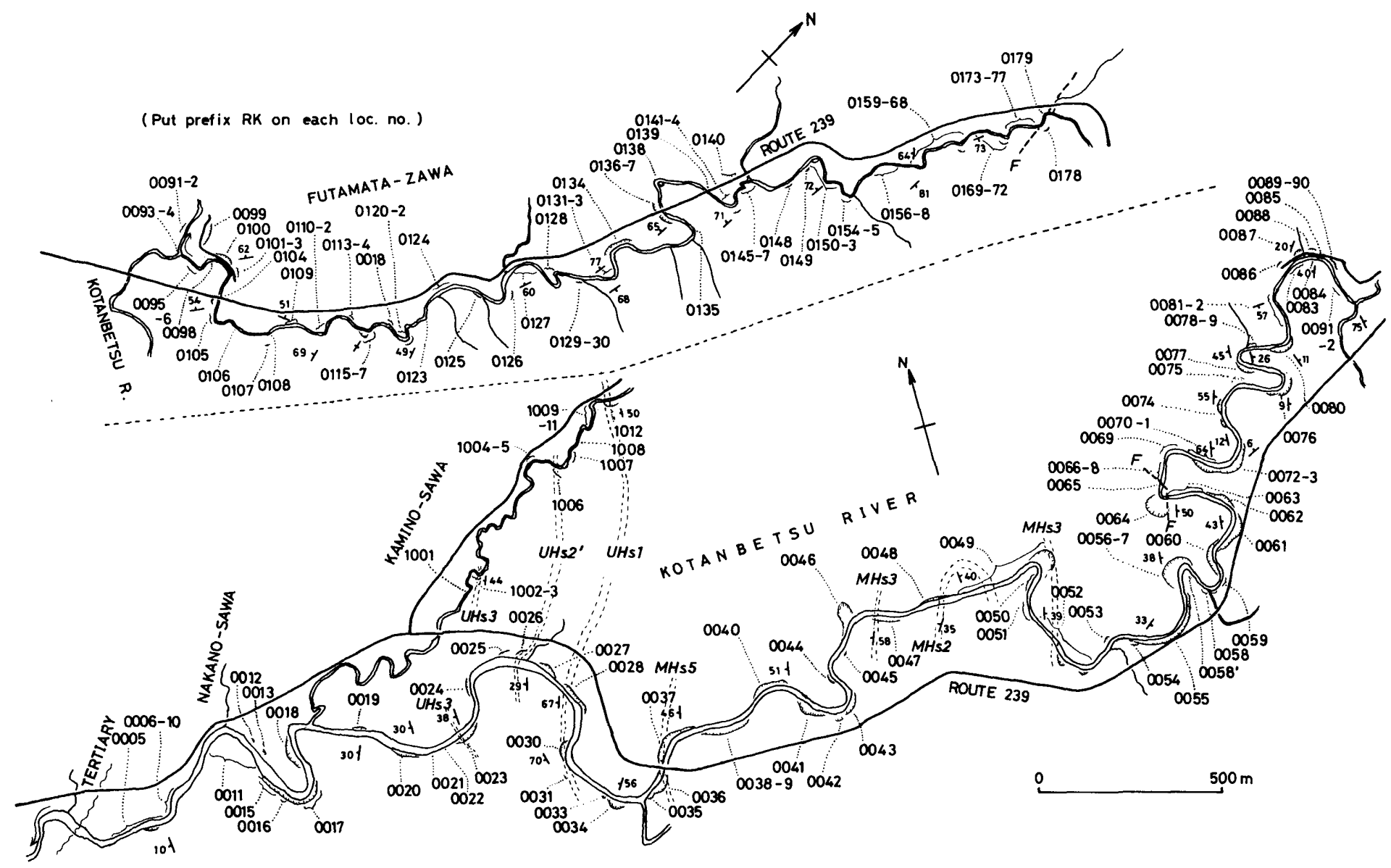

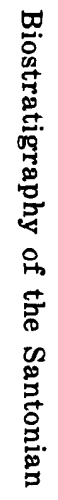

Fig. 22. Route map along the Kotanbetsu River. 


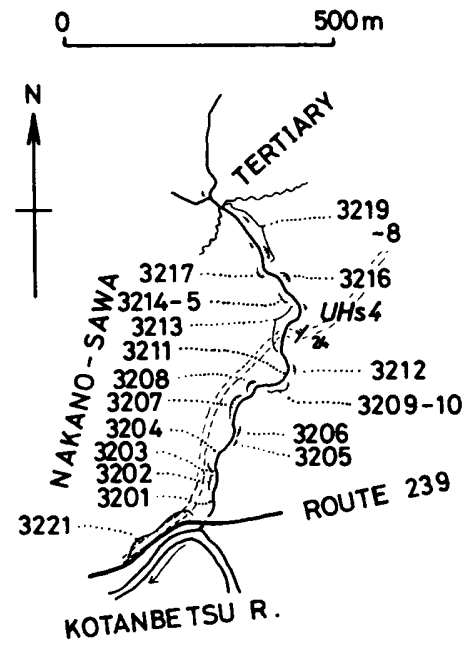

(Put prefix RK on each loc. no.)

Fig. 23. Route map along the Nakanosawa in the Kotanbetsu area.

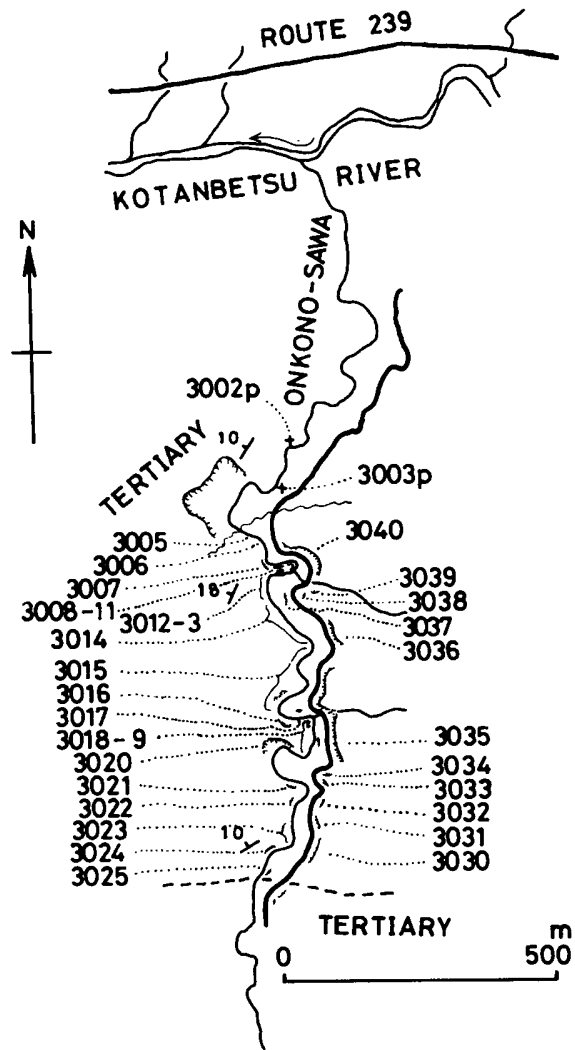

(Put prefix RK on each loc. no.)

Fig. 24. Route map along the Onkonosawa in the Kotanbetsu area. 


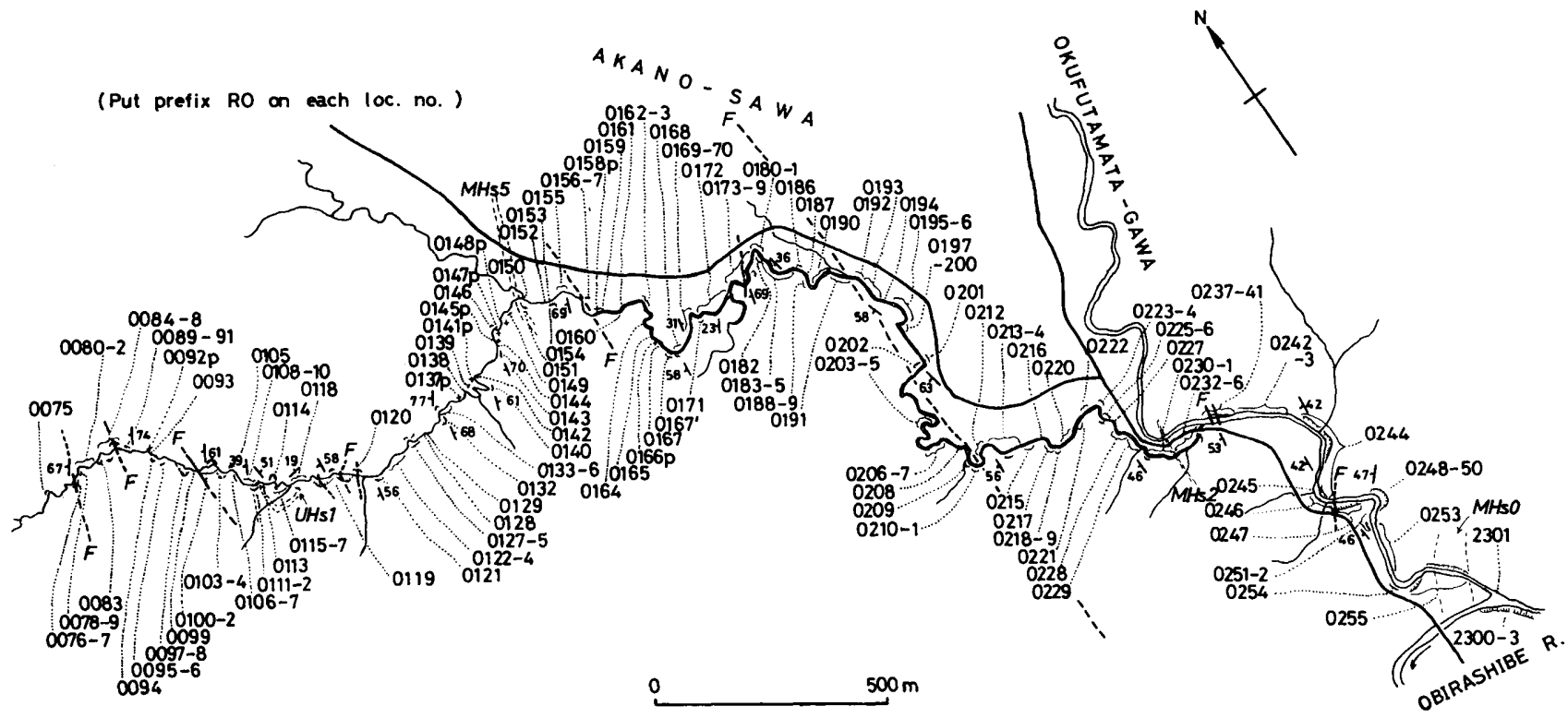

Fig. 25. Route map along the Akano-sawa in the Obira area. 


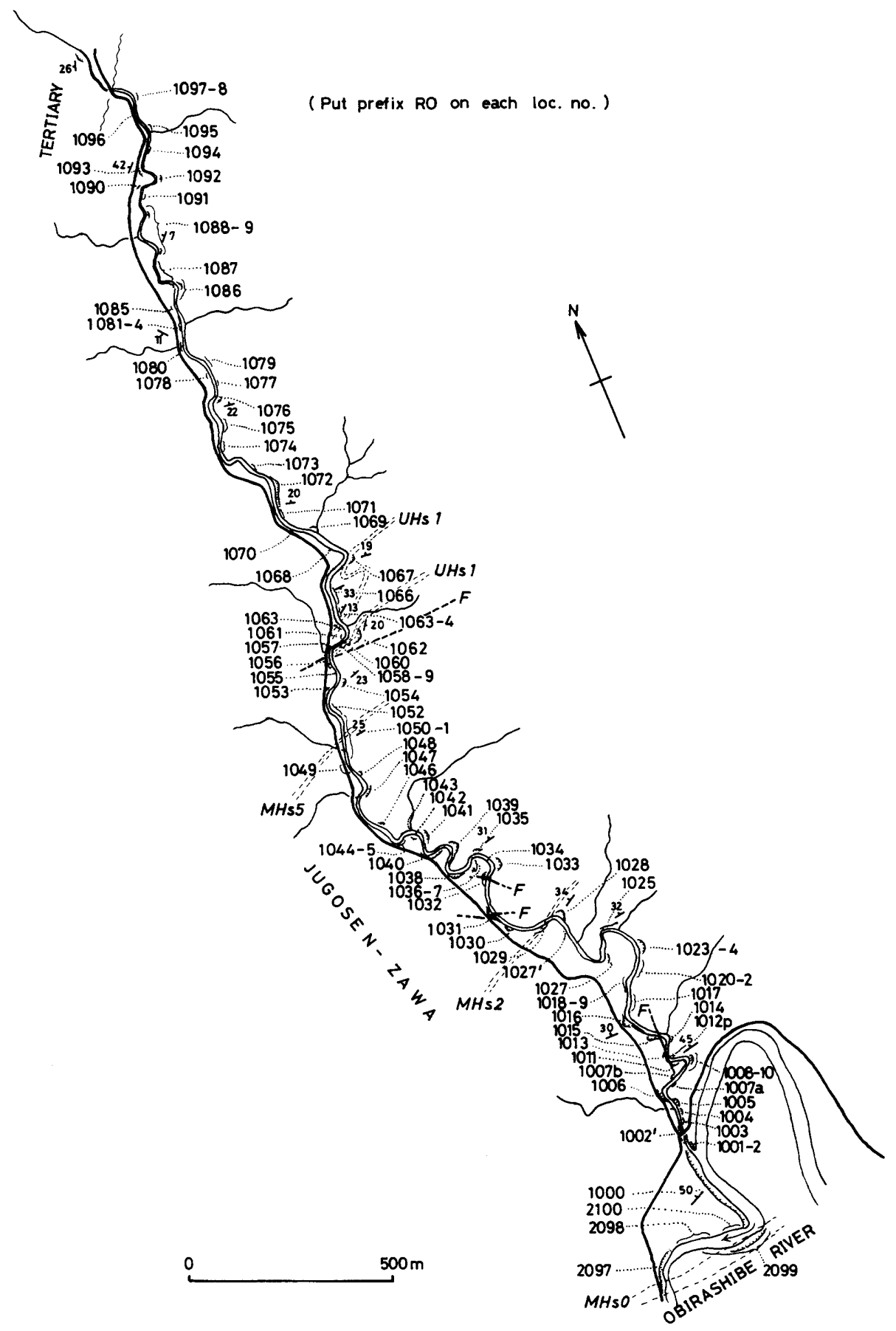

Fig. 26. Route map along the Jugosen-zawa in the Obira area. 


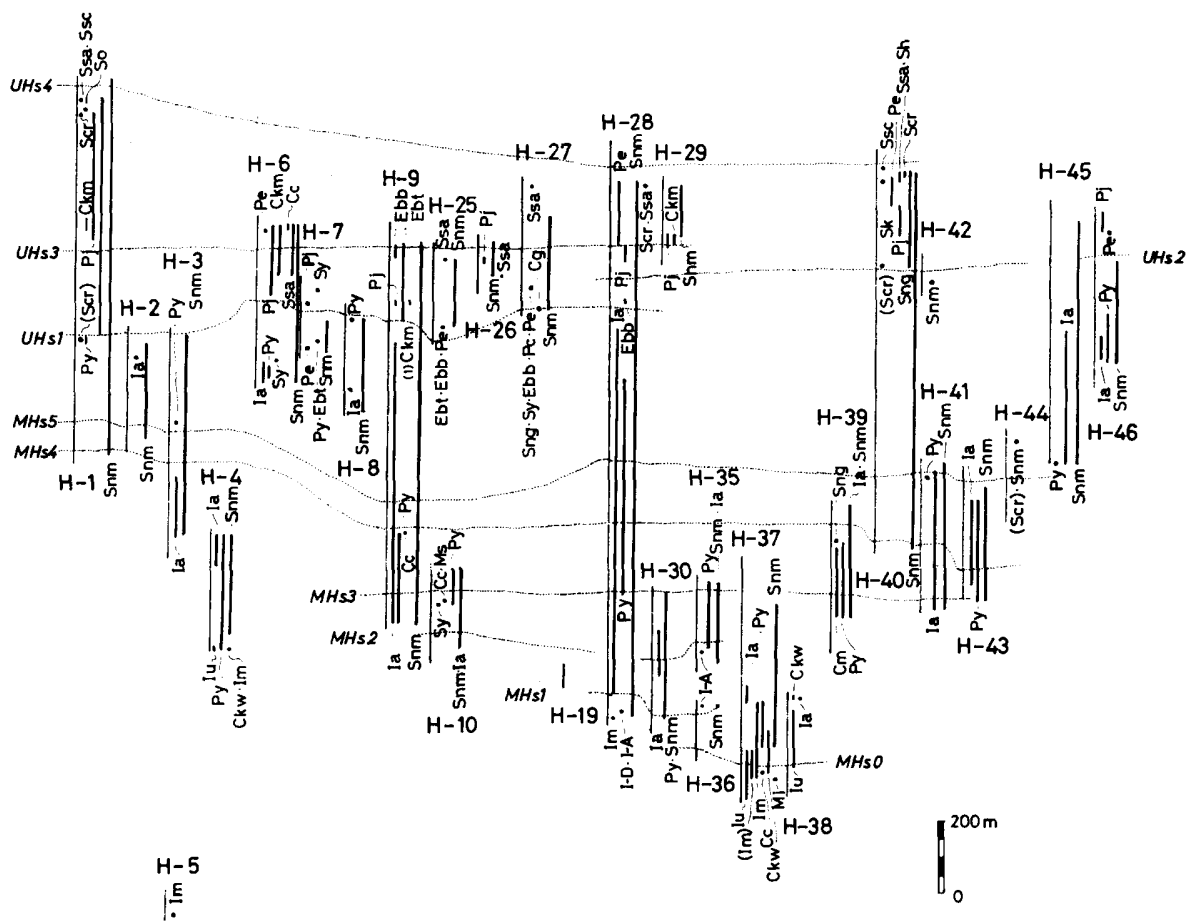

Fig. 27a. Compiled inoceramid successions of the Upper Yezo Group in the Haboro area, Hokkaido. (1) is horizon of specimens collected by OKADA and Matsumoto (1969).

$\mathrm{Iu}$ : Inoceramus uwajimensis, Im: I. mihoensis, (Im) : I. aff. mihoensis, I-A : I. sp. A, I-C: I. sp. C, I-D : I. sp. D, Ia:I. amakusensis, Cc: I. (Cordiceramus) cordiformis, Cm: I. (C.) mukawaensis, Ckw I. (C.) kawashitai, Ckm: I. (C.) kanmerai, Ebb: I. (Endocostea) balticus s.s., Ebt: $I$. (E.) balticus toyajoanus, Py: Platyceramus yubariensis, $\mathrm{Pe}:$ P. ezoensis, $\mathrm{Pj}:$ P. japonicus, $\mathrm{Sy}:$ Sphenoceramus yokoyamai, Snm: S. naumanni, Sng: S. nagaoi, So: S. orientalis, Ssc: S. schmidti, Sk: S. kiritachiensis, Sh: S. haboroensis, Saf: S. africanus, Ssa : S. sanrikuensis, Scr: S. cristatus, (Scr) : S. aff. cristatus, Mi: Mytiloides aff. incertus, Ms: $M$. aff. striatoconcentricus 


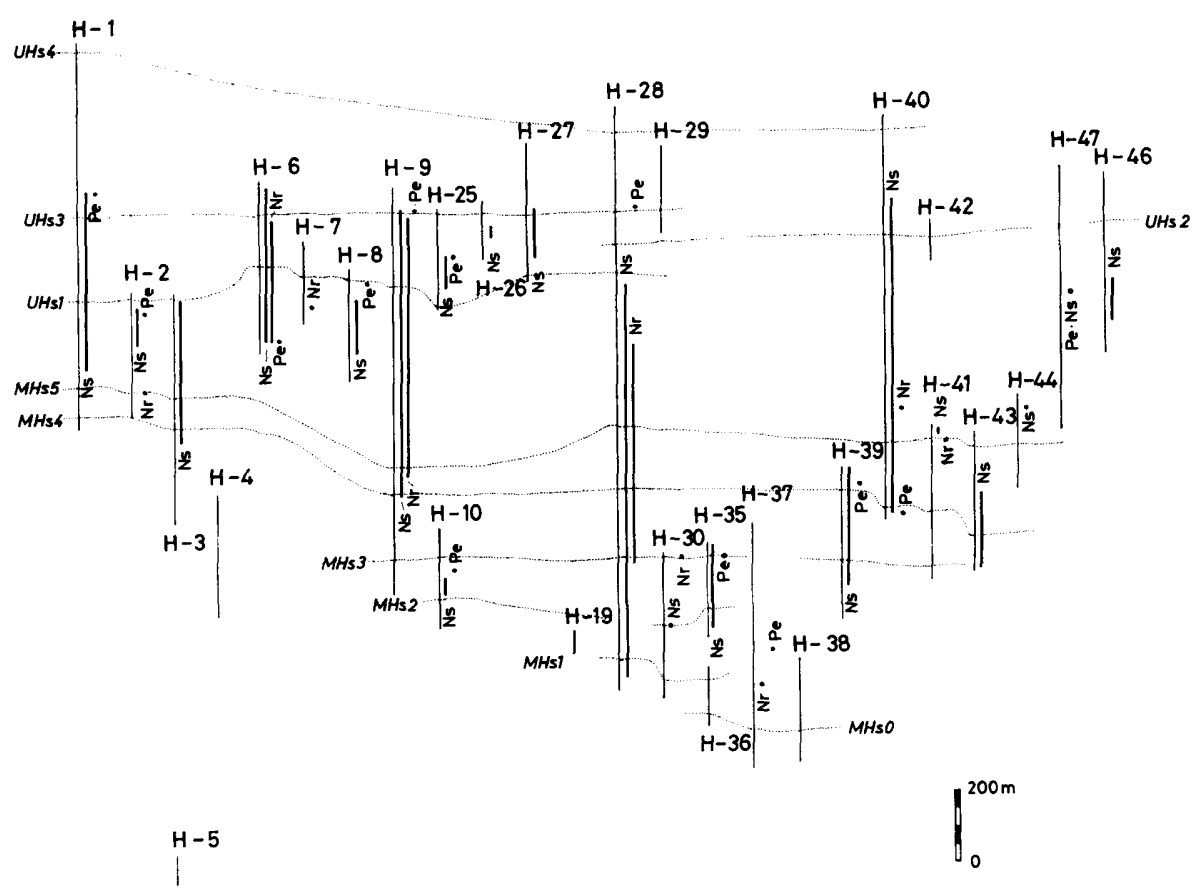

Fig. 27b. Compiled phylloceratid ammonoid successions in the Upper Yezo Group of the Haboro area, Hokkaido.

$\mathrm{Nr}$ : Neophylloceras ramosom, Ns: N. subramosum, Pe: Phyllopachyceras ezoense 


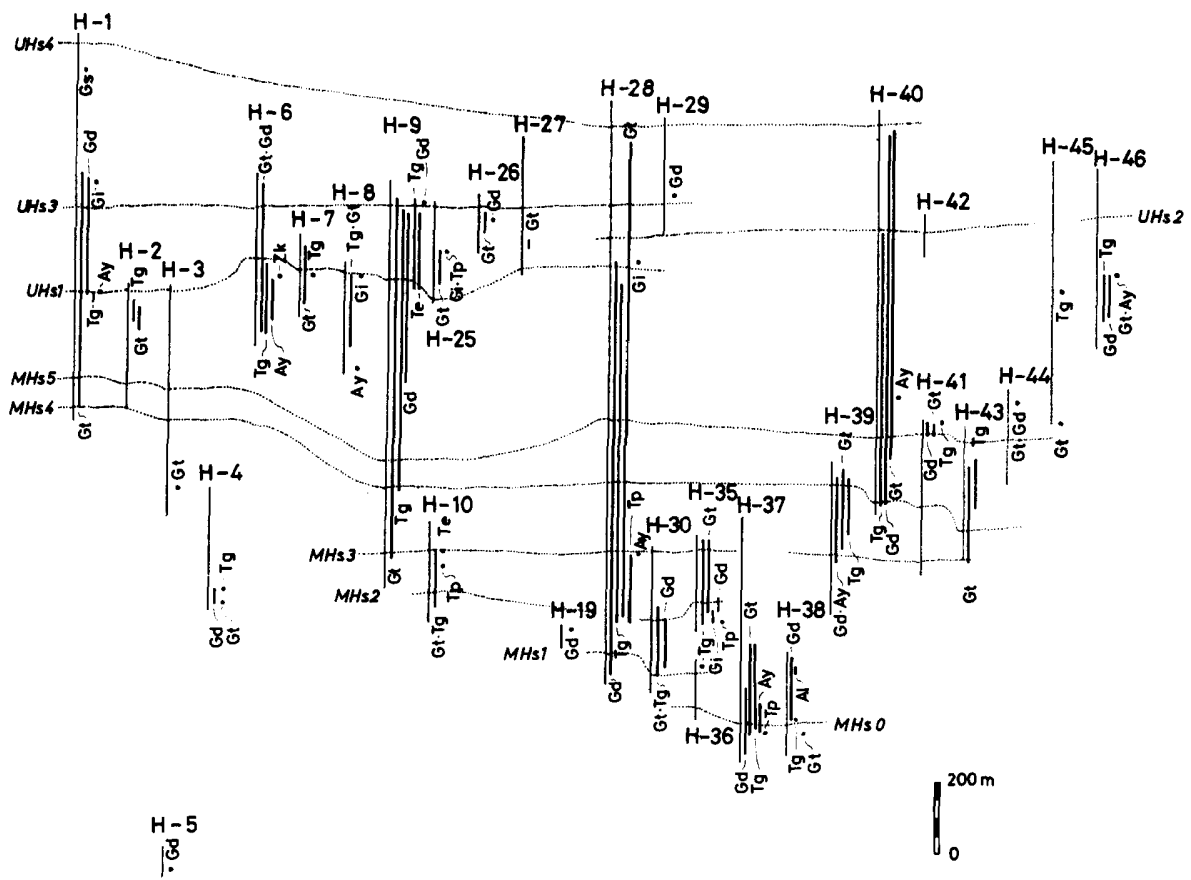

Fig. 27c. Compiled tetragonitid ammonoid successions in the Upper Yezo Group of the Haboro area, Hokkaido.

$\mathrm{Tg}$ : Tetragonites glabrus, Tp: T. popetensis, Te: T. epigonus, Zk: Zelandites kawanoi, Gt: Gaudryceras tenuiliratum, Gd: G. denseplicatum, Gi: G. intermedium, Gs: G. striatum, Al: Anagaudryceras limatum, Ay: A. yokoyamai 


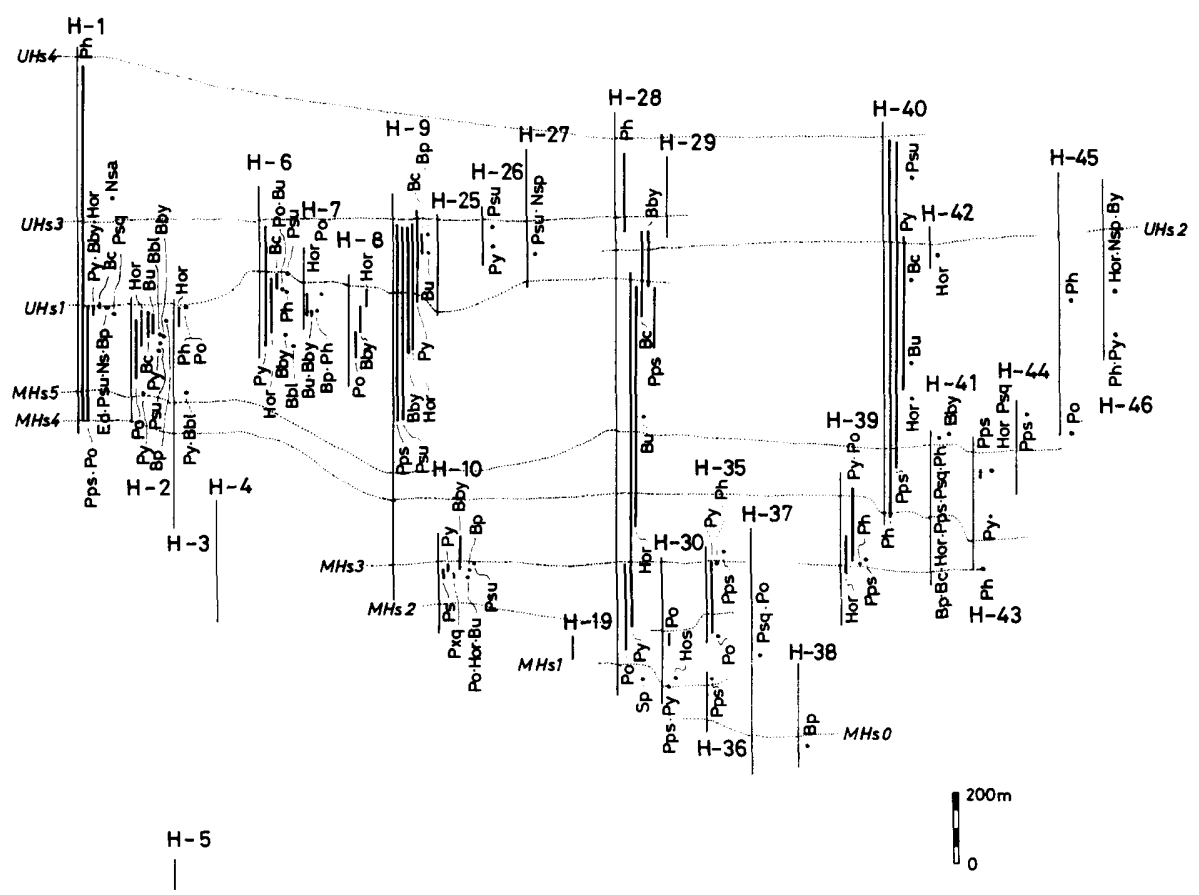

Fig. 27d. Compiled heteromorph ammonoid successions in the Upper Yezo Group of the Haboro area, Hokkaido.

Bby: Baculites bailyi, Bu: B. uedae, Bbl: B. boulei, Bc: B. capensis, $\mathrm{Bp}$ : B. princeps, Hos: Hyphantoceras oshimai, Hor: H. orientale, Ed: Eubostrychoceras densicostatus, Nsp: Neocrioceras spingerum, Nsa: N.(?) sanushibensis, Pxq: Pseodoxybeloceras quadrinodosum, $\mathrm{Po}$ : Polyptychoceras obstrictum, Ph: P. haradanum, Psq: P. subquadratum, Pps: P. pseudogaultinum, Psu: P. subundulatum, Py: P. yubarense, $\mathrm{Sp}$ : Scaphites pseudoequalis. 


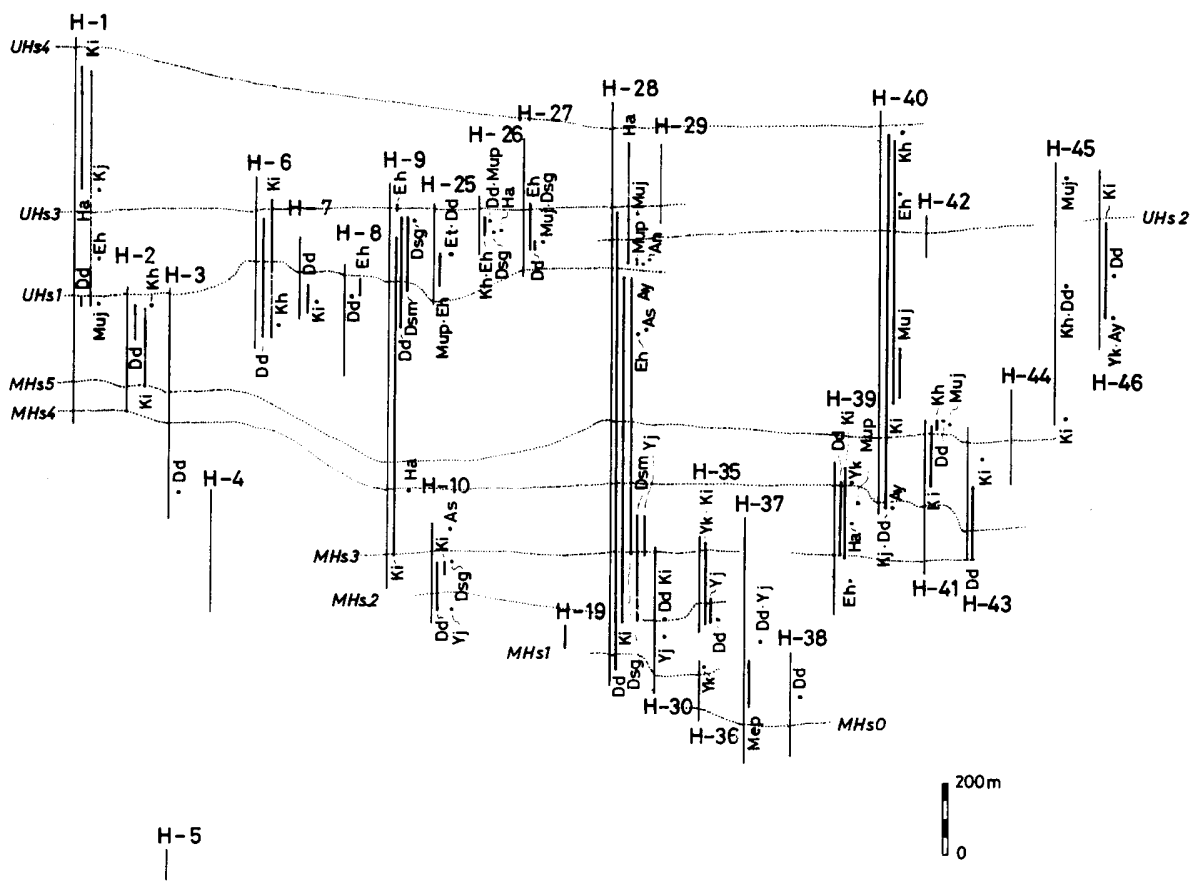

Fig. 27e. Compiled desmoceratacean ammonoid successions in the Upper Yezo Group of the Haboro area, Hokkaido.

$\mathrm{Jm}$ : Jimboiceras mihoense, Mep: Mesopuzosia pacifica, Ki: Kitchinites ishikawai, $\mathrm{Kh}: K$. haboroensis, $\mathrm{Kj}: K$. japonicus, Dd: Damesites damesi, Dsm: D. semicostatus, Dsg: D. sugata, $\mathrm{Ha}$ : Hauericeras angustum, $\mathrm{Yk}$ : Yokoyamaoceras kotoi, Yj: Y. jimboi, As: Anapachydiscus sutneri, Ay: A. deccanensis yezoensis, An: A. naumanni, Muj: Menuites japonicus, Mup: M. pusillus, Eh: Eupachydiscus haradai, Et: E. teshioensis 


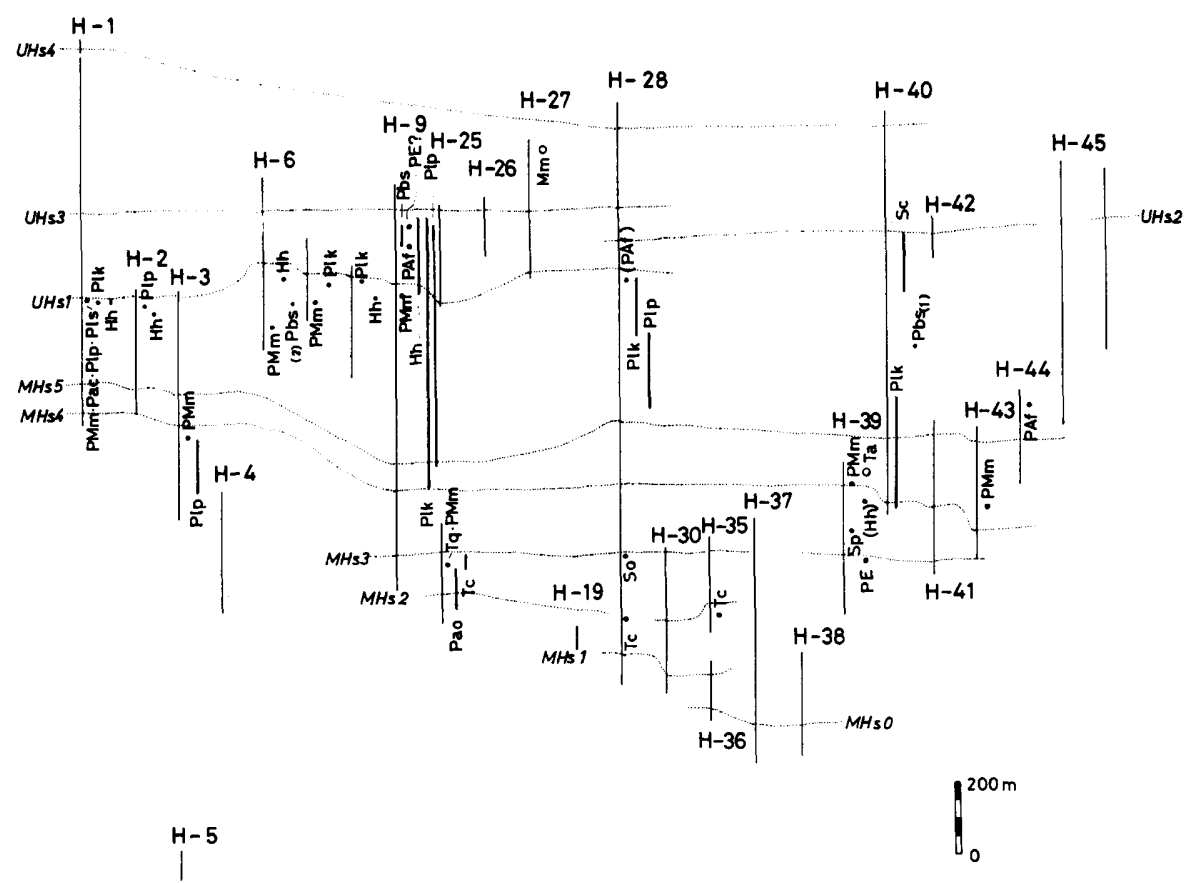

Fig. 27f. Compiled texanitine ammonoid successions in the Upper Yezo Group of the Haboro area, Hokkaido. Open circles are inferred horizon of floated nodules. (1) is adopted from Matsumoto and Hirano (1976), (2) from Matsumoto (1970) and (3) from Matsumoto and Takahashi (1986).

$\mathrm{Sp}$ : Sornayceras proteus, So: S. omorii, Pbs: Protexanites bontanti shimizui, PAf: P. fukazawai, (PAf): P. aff. fukazawai, PMm: P. minimus, Pao: Paratexanites aff. orientalis, Pac: P. compressus, Plk: Plesiotexanites kawasakii, Plp: P. pacificus, Pls: P. shiloensis, PE: P. (Eutexanites) sp., Tq: Texanites quinquenodosus, Tc: T. collignoni, Ta: T. amakusensis, Sc: Submortoniceras condamyi, $\mathrm{Hh}:$ Haboroceras haboroense, $(\mathrm{Hh}):$ Haboroceras, aff. haboroense, $\mathrm{Mm}$ : Menabites mazenoti 
Table 1. List of inoceramids and ammonites from the Upper Yezo Group in the Haboro area.

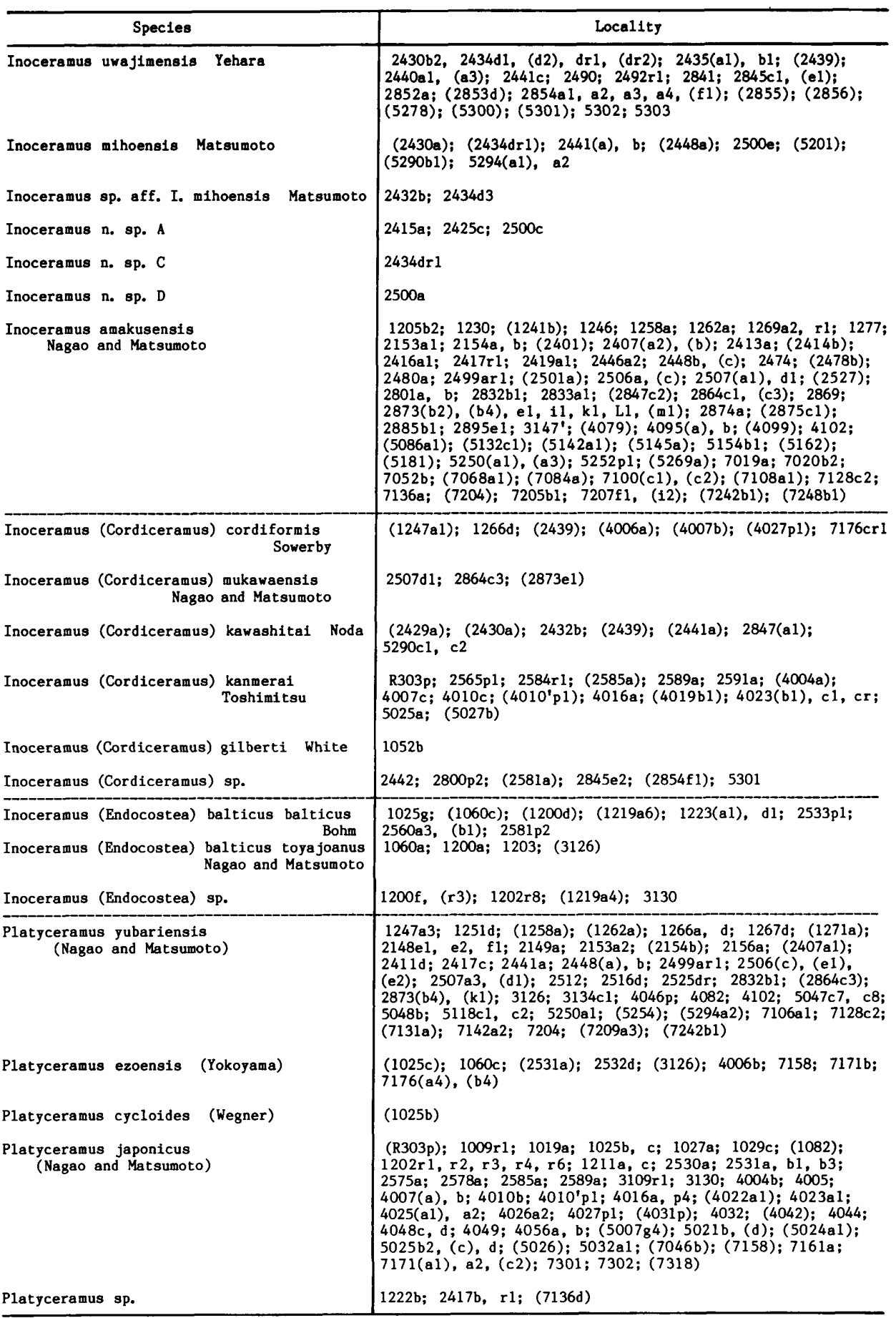

Put prefix RH on each loc. no., ( ): cf., p: floated sample 
Table 2. Continued.

\begin{tabular}{l|l}
\hline \multicolumn{1}{|c|}{ Species } & \multicolumn{1}{c}{ Local1ty } \\
\hline $\begin{array}{l}\text { Sphenoceramus yokojama1 } \\
\text { (Nagao and Matsumoto) }\end{array}$ & $(1025 \mathrm{c}) ;(1267 \mathrm{c}) ;(3108 \mathrm{~b} 2) ;(4082)$ \\
Sphenoceramus naumanni (Yokoyama) & (R303p); 1003a, b, c, d; 1009(a), b; 1019a; 1025b, c, d, g;
\end{tabular}
1027 (a) b; 1028 , b; $1029 a, b, c ; 1031 a, b ; 1032 a ; 1034 a^{8}$ $1042 \mathrm{a} ; 1045 \mathrm{a}$, b; $1052 \mathrm{a}, \mathrm{b} ; 1060 \mathrm{a}$, (b); $1070 \mathrm{a}, \mathrm{b}, \mathrm{c}, \mathrm{e} ; 1079$; (1082); (1094); $1097 \mathrm{a}, \mathrm{b} ; 1099 ; 1109 ; 1110 ; 1111 ; 1115 \mathrm{~b}$; $1200 \mathrm{a}, \mathrm{cl}, \mathrm{c2}, \mathrm{d}, \mathrm{el}, \mathrm{e} 2, \mathrm{f}, \mathrm{g}, \mathrm{r} 1, \mathrm{r} 4, \mathrm{r} 5 ; 1202 \mathrm{~d}, \mathrm{r} 5, \mathrm{r} 7$, r9; 1203; 1204a, (r5); 1205a; 1206c; (1207); 1209; 1214a, b; $1215 ; 1216 \mathrm{a}$, (b); $1217 \mathrm{c}, \mathrm{d}$; e, h, i; $1218 \mathrm{al}, \mathrm{a2} ; 1219 \mathrm{al}, \mathrm{a} 3$ a4, a5, a6, a8; $1222 \mathrm{a} ; 1225 \mathrm{a}, \mathrm{b} ; 1226 \mathrm{al}, \mathrm{bl} ; 1228 \mathrm{a}, \mathrm{g}, \mathrm{hl}$; $1229 \mathrm{a}$, b; 1230 ; $1241 \mathrm{a}$, b; $1242 \mathrm{a}$, b; $1244 \mathrm{a}$, b, c; $1245 \mathrm{a}, \mathrm{b}$; $1246 ; 1247 \mathrm{al}, \mathrm{a} 2, \mathrm{a3},(\mathrm{b}), \mathrm{c} ; 1251 \mathrm{a}, \mathrm{b} 1, \mathrm{~b} 2, \mathrm{~b} 3, \mathrm{c} 1, \mathrm{c} 2, \mathrm{c} 3$, c4, d; $1253 \mathrm{a} 1$, a2, a3, b2; $1254 \mathrm{~b} ; 1258 \mathrm{a} ; 1262 \mathrm{a} ; 1266 \mathrm{a}, \mathrm{b}, \mathrm{d}$, e; $1267 \mathrm{a}, \mathrm{b}, \mathrm{c}$, d; $1269 \mathrm{a}$, (a2); $1271 \mathrm{a}, \mathrm{b} ; 1272 \mathrm{a}$; $1275 \mathrm{a}$; $1277 ; 1280 \mathrm{a}, \mathrm{c}, \mathrm{d} ; 2148 \mathrm{e} 1$, e2, f1; 2149a; 2150a; 2153a2; 2154b; 2156a, b; 2402a; 2405; 2406a; 2407al; 2411a, d; 2413a; 2414b; 2415a, b; 2417c, d; 2419a; 2421a; 2425c; 2429a; (2430a); 2432b; 2441a; 2442; 2448c; 2451; (2452a); $2473 \mathrm{r}$; (2474); 2478a; 2499arl; 2500a, (c), (d), e; 2506c, d; 2507al, a3, d1; 2508a; 25l1b, c, d, e, f, g, hl, kl; 2516a, d; $2518 \mathrm{pl}$; 2520a, b; 2526d; 2530a, b, c, d, e, f; 2531 b1, b3; 2532 b, (f), i; 2533pl; 2556cl, f1, f 2; 2560al, b1; (2564a); 2565pl; 2575a; (2581p2); 2801a; 2802pl; 2830a; $2831 \mathrm{cl}$, dl; 2832b1; 2833a2, bl; (2864c3); 2865a1, el; 2867; 2869; 2873b2, b3, b4, b5, e1, i, k1, L1; 2875c1; 2880; $2882 \mathrm{bl}$; 2883bl, b2, b3; 2885al; 2886b2; 2887a; 2888 1 ; 2890; 2894; 2895e 1, pl; 2897; 2899; 3109d1, d 2, d3, d4, d5; 3114; $3120 ; 3123 b ; 3126 ; 3128 a$; 3129b; $3134 \mathrm{cl},(c 2), c 3, c 4 ;$ $3135 \mathrm{a}, \mathrm{b}, \mathrm{c} ; 3137 ; 3138 ; 3147^{\prime} ; 3155 ; 4005 ;(4007 \mathrm{~b}) ; 4010 \mathrm{a}$, c; 4011(a1), br; (4016a); (4021a1); 4022al; 4023(cl), (cr); 4025al; 4026al; 4031p; 4032; 4042; 4046p; 4052p1; 4061; 4062; 4063; 4065; 4069a, b; 4072a; 4073; 4074, p; 4080a; 4082; 4095a; 4099; 4102; 4103; (4106); 4109; 5007c1, c2, 82, g3, j2, j5, (j7), (q1); (5021c); 5024a1, b; 5025b; 5027b; (5029a); 5032a1; (c1), (r1), r2; 5047c1, c2, c3, c4, c5, c6, c7, c8, c9; $5048 \mathrm{~b} ; 5049 \mathrm{bl}, \mathrm{cl}, \mathrm{c2}, \mathrm{c4}, \mathrm{c5} ; 5050 ; 5051 \mathrm{a}$; 5054a, b; 5055b1; 5056b; 5059a1, (b1); 5063a2, a3, a4, bl ; $5065 \mathrm{~b}, \mathrm{c}, \mathrm{d} ; 5072 \mathrm{~b} 1 ; 5075 \mathrm{al}$, el, f1, f2; 5079al, a2; 5080b1, 5082a1, a 2, в3; 5083; 5085a; 5086a1, c1, e1, e2, f1; 5087al, b1, d2; 5095b1, b2; 5097; 5102a3, b1, b2; 5103; 5106a; 5107al; 5118c1, c2; $5120 \mathrm{bl}$, b2; 5132b1, c1, (c2); 5133al, a2, a3, b2 ; 5152; 5181; 5250a1, a2; (5256); 5257; 5260; (5267); 5283(b1), b2, (b3), b4, d1; (7011); 7012b; 7013a, b, c; $7014 a, r 1 ; 7015 a, b ; 7018 a 1, b ; 7019 a, b 2 ; 7020 a 2$, b1, b2, c, d1, d3; 7021a; 7027b1; 7028b1, b2, b3; 7029b1, (b2), b3; 7045; 7046a, b; 7050a, b; 7052a, b, c; 7053c1; 7055a; $7058 \mathrm{a} ; 7060 \mathrm{a} ; 7067 \mathrm{a}, \mathrm{b} 1, \mathrm{~b} 2, \mathrm{c} 1, \mathrm{c} 2 ; 7068 \mathrm{a} 1, \mathrm{a} 2, \mathrm{~b} ; 7069 \mathrm{a}$ b; 7080a, d, e; 7081a, b, c; 7084a; 7100c1, c2; 7106a, bl; 7108al; 7110al, a2; 7111b1; 7112al, a2, b; 7116a; 7128c2, c3, d1; 7142al, a 2; (7143a); 7150a1, (a3); 7152b1, b2; $7176 a 1, a 2, a 3, a 4, a 5,(b 1), b 3, b 4,(b 5),(b 6), b 7, c 2$, c3, c4, c5, c6, c7, (c8), cr1, d1; 7202a1; 7204, (7205b1); $7207 c 1, d 1, f 2$, i2; 7209a3; 7216a, b, c, d; 7221a, b1, b2, b3, b4; 7227a; 7239a, b; (7242b1); 7248r1, r2, r3, r4; 7250a; (7301b2); 7302al; (7310a); 7311bl, (b2)

Sphenoceramus nagaoi (Matsumoto and Ueda) R346p6; (1045a); (1226b1); (2873b3); (5007j2); (5049c1); $7013 \mathrm{a}, \mathrm{c} ;(7174 \mathrm{a}) ; 7176(\mathrm{~b} 4), \mathrm{b} 6, \mathrm{c} 4,(\mathrm{cr} 1) ; 7302 \mathrm{a} 1$

Sphenoceramus orientalis (Sokolow)

(5007h1)

$5007 \mathrm{jl}$; (7009a)

5007j5; (7176al)

7176(a1), c1

$2511 \mathrm{k} 1$

R346p6; R359c, d; 1079; (1109); (1111); 2532f, h; (4010c); (4023c1); (5007j8); 7176al, a2, b3, (c4), c8, (cr1), (c10), c11

Sphenoceramus cristatus sp. nov.

Sphenoceramus sp. aff. S. cristatus sp. nov.

Sphenoceramus sp.

R346p6; 2532i; (5007g1); 7176b7, c4, crl; 7311bl

5049c4; 7013a; 7239a

(2883b1); 4014a; 4074p; 5269a; 7014a; 7020al; 7111bl; $7128 \mathrm{a} 1 ; 7158 ; 7176 \mathrm{c} 2$, cr1; 7311b1 
Table 3. Continued.

\begin{tabular}{|c|c|}
\hline Species & Locality \\
\hline $\begin{array}{l}\text { Mytiloides sp. aff. M. incertus (Jimbo) } \\
\text { Mytiloides sp. aff. M. striatoconcentricus } \\
\text { (Gumbel) }\end{array}$ & $\begin{array}{l}2434 \mathrm{dr} 1 \\
1266 \mathrm{~d}\end{array}$ \\
\hline Mytiloides sp. & $\begin{array}{l}\text { R303p; 1052b; 1099; 1217i; (2417d); (2506d); 2533pl; 2849a; } \\
\text { 5049c4; 5050; 7018al; 7052a; (7132a); 7207d1 }\end{array}$ \\
\hline Neophylloceras ramosum (Meek) & $\begin{array}{l}1200 \mathrm{c} 2,(\mathrm{f}) ;(1202 \mathrm{~b}) ; 1219 \mathrm{a} 5, \mathrm{a} ; \quad(1242 \mathrm{~b}) ; 2156 \mathrm{r} 1 ;(2442) ; \\
2506 \mathrm{c} ; 2507 \mathrm{~d} 1 ; 2516 \mathrm{~d} ;(3126) ; 4032 ; 4102 ; 5065 \mathrm{a} ;(7055 \mathrm{a}) ; \\
7106 \mathrm{a}\end{array}$ \\
\hline Neophylloceras subramosum Spath & 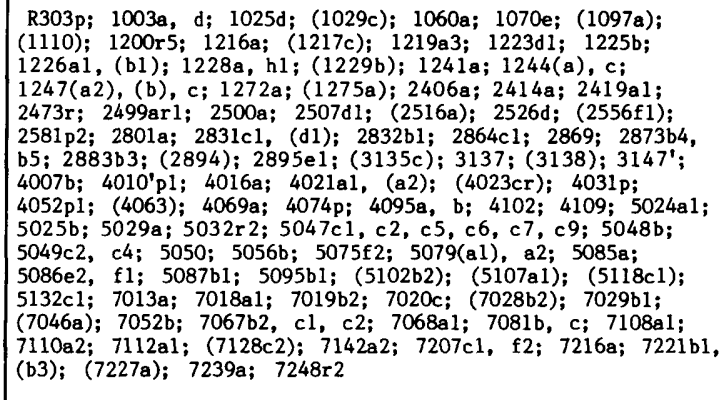 \\
\hline Neophylloceras sp. & 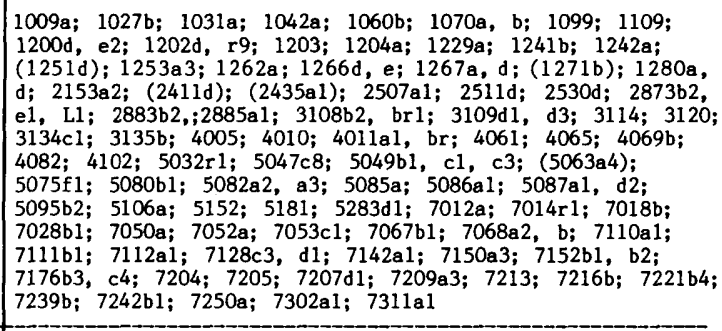 \\
\hline Phyllopachyceras ezoense (Yokoyama) & $\begin{array}{l}\text { 1070b, e; (1215); 1223d1; (1247b); 1253a3; 1267c; 2446al; } \\
(2531 \mathrm{a}) ; 2831 \mathrm{cl} ; 2895 \mathrm{el} ;(3134 \mathrm{c} 3) ;(4074 \mathrm{p}) ; 4102 ; 5024 \mathrm{al} ; \\
\text { 5086e2; 5086f1; 708lc; 7248r2 }\end{array}$ \\
\hline Phyllopachyceras sp. & 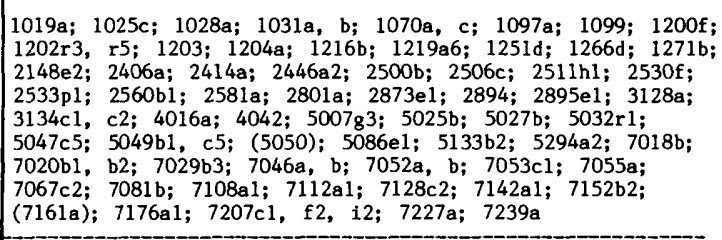 \\
\hline Anagaudryceras limatum (Yabe) & $(2432 b) ;(2439) ;(2844 a) ; \quad(2845 b 1)$ \\
\hline Anagaudryceras yokoyamai (Yabe) & $\begin{array}{l}1241 \mathrm{r} 2 ;(2506 \mathrm{c}) ; 2885 \mathrm{al} ; 22895 \mathrm{el} ;(3155) ; 4069 \mathrm{~b} ; 4095 \mathrm{a} \\
(5049 \mathrm{c} 2) ; \quad(7053 \mathrm{a} 1) ; 7142 \mathrm{al}\end{array}$ \\
\hline Anagaudryceras sp. & $\begin{array}{l}1115 \mathrm{a} ; 1200 \mathrm{c} 2 ; 1267 \mathrm{c} ; 2406 \mathrm{a} ; 2436 \mathrm{a} ; 2873 \mathrm{~b} 5, \mathrm{kl} ; 2883 \mathrm{~b} 2 ; \\
(2895 \mathrm{e} 1) ; 3120 ; 4063 ; 5047 \mathrm{c} 7, \mathrm{c9} ; 5063 \mathrm{a} 4 ; 5079 \mathrm{a} 2 ;(5087 \mathrm{al}) \\
7106 \mathrm{a} ; 7108 \mathrm{al} ; 7248 \mathrm{rl}, \mathrm{r2} ; 7302 \mathrm{a} 1\end{array}$ \\
\hline $\begin{array}{l}\text { Zelandites kawanoi (Jimbo) } \\
\text { Zelandites sp. }\end{array}$ & $\begin{array}{l}1202 r 7 ; 4069 a \\
1099 ;(2506 c) ; 2849 a ; 5047 c 6 ; 7110 a 2\end{array}$ \\
\hline Gaudryceras denseplicatum (Jimbo) & 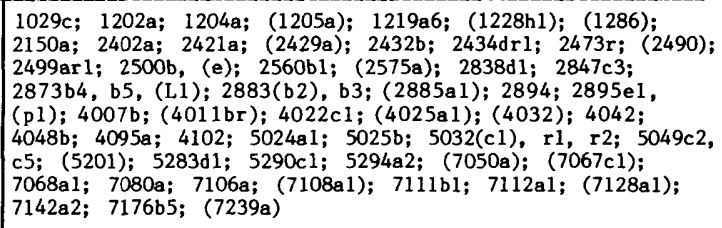 \\
\hline
\end{tabular}


Table 4. Continued.

\begin{tabular}{|c|c|}
\hline Species & Locality \\
\hline Gaudrycerss tenuiliratum Yabe & 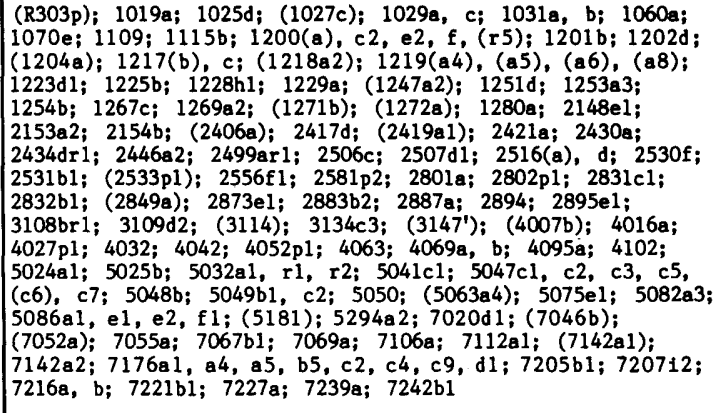 \\
\hline Gaudryceras intermedium (Yabe) & $\begin{array}{l}\text { (R303p); 1070d; 1223d1; 2414a; 2419al; 2473r; 2560bl; } \\
3134 c 4 ; 5029 \mathrm{a}\end{array}$ \\
\hline Gaudryceras striatum (Jimbo) & $(500786)$ \\
\hline Gaudryceras sp. & 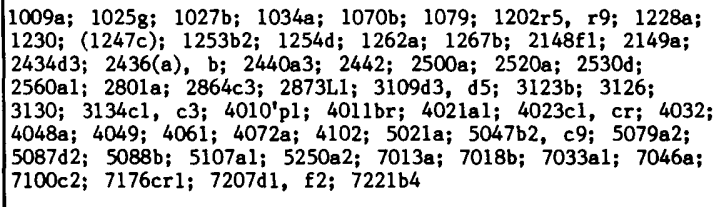 \\
\hline Gaudryceratinae gen. et sp. indet. & $\begin{array}{l}1242 \mathrm{a} ; 1267 \mathrm{~d} ; 1271 \mathrm{a} ; 2887 \mathrm{a} ; 2895 \mathrm{e} 1 ; 4063 ; 4074 \mathrm{p} ; 4082 ; 4102 ; \\
\text { 4109; 5082a3; (5294a2); 7014a; 7018a1; 7053cl }\end{array}$ \\
\hline Tetragonites glabrus (Jimbo) & 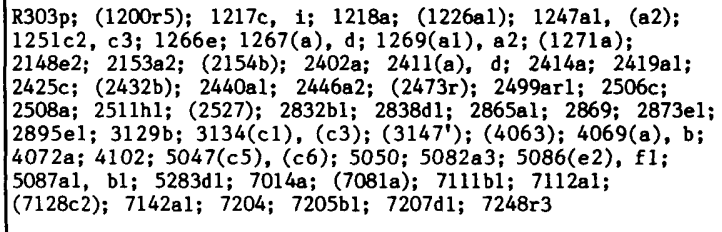 \\
\hline Tetragonites epigonus (Kossmat) & $1200 f ;(1204 a) ; 1219 a 6 ;(1271 b)$ \\
\hline Tetragonites popetensis Yabe & $\begin{array}{l}(1070 a) ;(1200 \mathrm{c} 2) ; 1204 a ; 1219 a 5 ;(1222 a) ;(1280 a) ;(2402 a) ; \\
(2414 a) ; 2434 d r 2 ;(2506 c)\end{array}$ \\
\hline Tetragonites sp. & 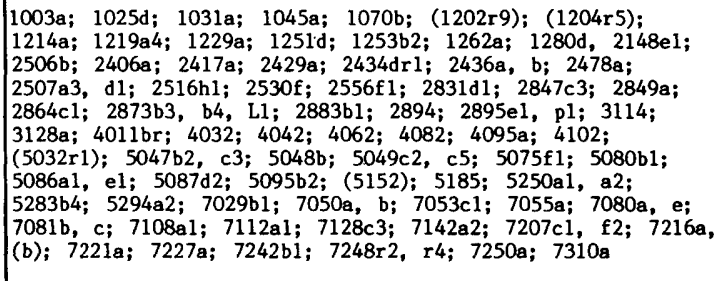 \\
\hline Tetragonitidae gen. et sp. indet. & $\begin{array}{l}1215 ; 2560 \mathrm{bl} ; 2873 \mathrm{~b} 5 ; \text { 4046p; }(4062) ; 4063 ; 4072 \mathrm{a} ; 5047 \mathrm{c} 6 \\
\mathrm{c7} ; 5049 \mathrm{c} 4 ; 5086 \mathrm{e} 2 ; 7029 \mathrm{~b} 3 ; 7069 \mathrm{a} ; 7106 \mathrm{bl} ; 7239 \mathrm{~b} ; 7311 \mathrm{~b} 2\end{array}$ \\
\hline Baculites bailyi & $\begin{array}{l}1200 \mathrm{f}, 8 ; 1204 \mathrm{r} 2 ; 1214 \mathrm{a} ; 1219 \mathrm{a} 3, \text { a6; } 1226 \mathrm{bl} ;(1262 \mathrm{a}) ; \\
(1266 \mathrm{~d}) ; 2530 \mathrm{e} ; 2556 \mathrm{fl} ; 3114 ; 3126 ; 3135 \mathrm{~b} ; 3137 ; 4082 ; \\
5047(\mathrm{c5}), \text { c7; 5050; 5082a2; (5097); 7111b1; 7142a2; (7204) }\end{array}$ \\
\hline Baculites uedae Matsumoto and Obata & $\begin{array}{l}\text { 1214a; 1280a; (2511i); 3114; 3126; 4069a; (5083); (5087b1); } \\
7020 \mathrm{c}\end{array}$ \\
\hline Baculites boulei Collignon & 4102; (5082a3); $5118 \mathrm{c} 1$ \\
\hline Baculites capensis & $\begin{array}{l}\text { 1200f; }(1214 \mathrm{~b}) ;(1216 \mathrm{~b}) ; 2526 \mathrm{~d} ; 2530 \mathrm{f} ;(2849 \mathrm{a}) ;(4062) ; \\
\text { 4069a; 5049c5; (c9); 5080b1; 5085a; 5086(a1), (e1); 5087d2; } \\
7029 \mathrm{~b} 2 ; 7112 \mathrm{a} 2\end{array}$ \\
\hline Baculites princeps & $1200 f ;(1266 d) ; 3126 ; 5049 c 2 ;(5086 \mathrm{e} 2) ; 7112 \mathrm{al}$ \\
\hline
\end{tabular}


Table 5. Continued.

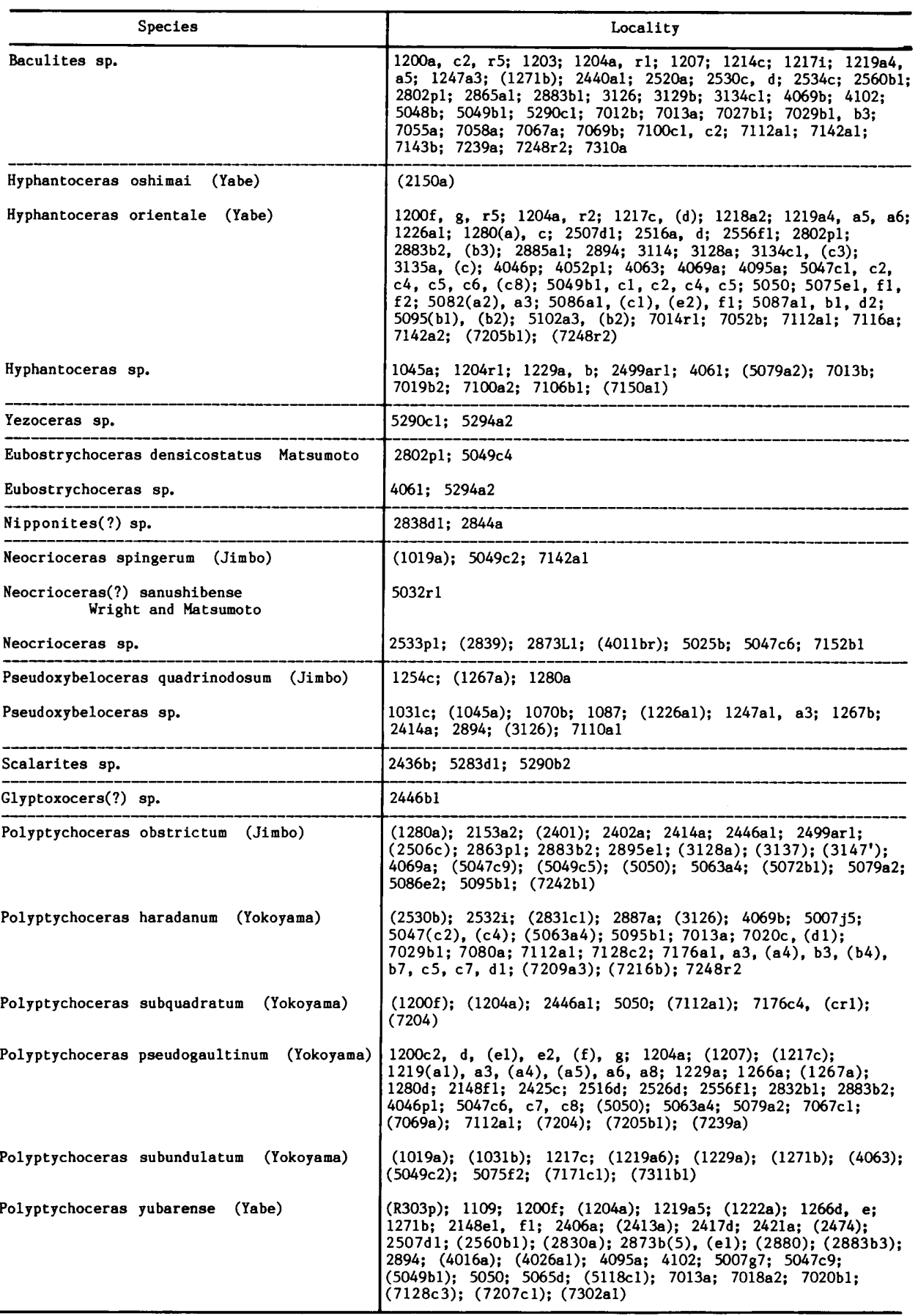


Table 6. Continued.

\begin{tabular}{|c|c|}
\hline Species & Locality \\
\hline Polyptychoceras sp. & 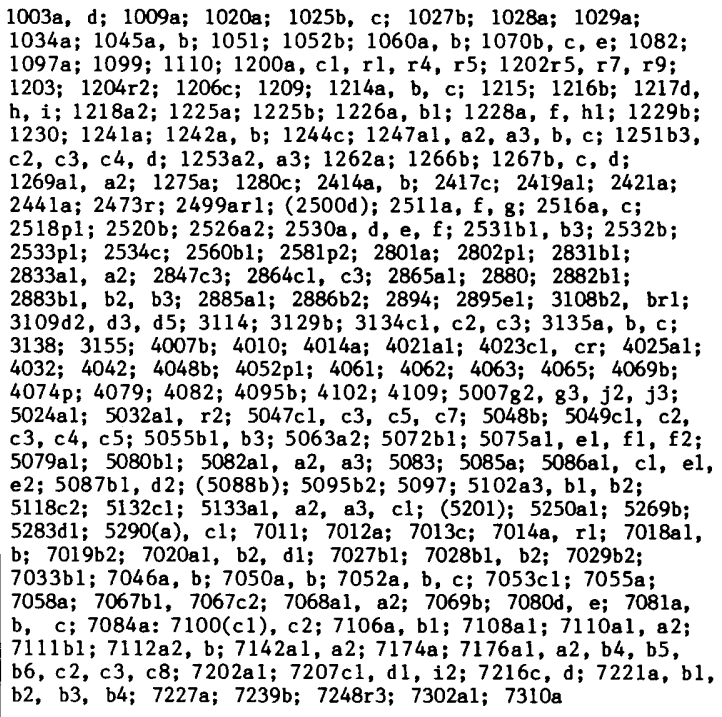 \\
\hline $\begin{array}{l}\text { Scaphites pseudoequalis Yabe } \\
\text { Scaphites sp. }\end{array}$ & $\begin{array}{l}(2500 \mathrm{c}) \\
2849 \mathrm{a}\end{array}$ \\
\hline Clioscaphites sp. & $(2838 d 1)$ \\
\hline Otoscaphites sp. & $2849 a ; 2855$ \\
\hline Jimboiceras mihoense Matsumoto & (2430b1) \\
\hline $\begin{array}{l}\text { Mesopuzosia pacifica Matsumoto } \\
\text { Mesopuzosia yubarensis (Jimbo) } \\
\text { Mesopuzosia sp. }\end{array}$ & $\begin{array}{l}(2448 \mathrm{a}) \\
(2500 \mathrm{~b}) \\
2432 \mathrm{~b} ; 2440 \mathrm{al}\end{array}$ \\
\hline $\begin{array}{l}\text { Ritchinites (Neopuzosia) haboroensis } \\
\text { Matsumoto and Inoma }\end{array}$ & 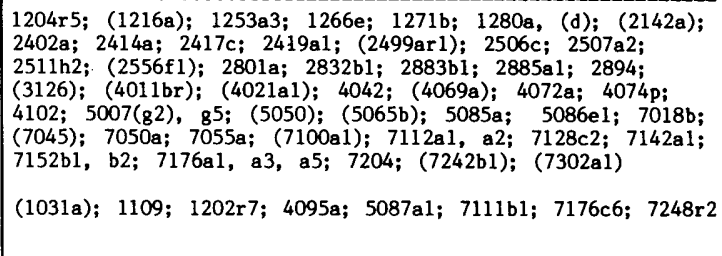 \\
\hline $\begin{array}{l}\text { Kitchinites (Neopuzosia) japonicus Spath } \\
\text { Kitchinites (Neopuzosia) sp. }\end{array}$ & 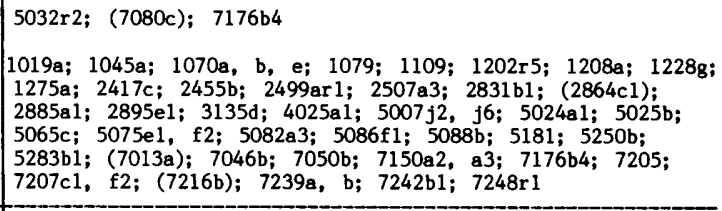 \\
\hline Puzosiinae gen. et sp. indet. & 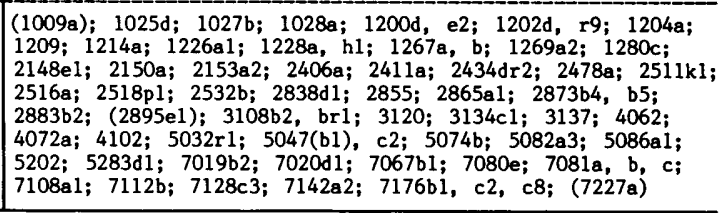 \\
\hline
\end{tabular}


Table 7. Continued.

\begin{tabular}{|c|c|}
\hline Species & Locality \\
\hline Damesites damesi (Jimbo) & 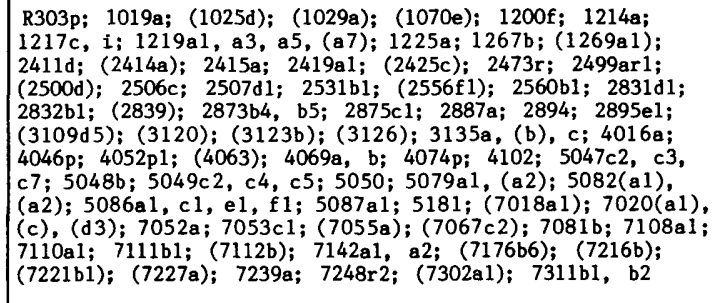 \\
\hline Damesites semicostatus Matsumoto & $\begin{array}{l}\text { 1200f; 1204a; 1217c; 1219a5; 2402a; 2413a; 2446a1, a2; } \\
2506 c \text { d; (2507d1) }\end{array}$ \\
\hline Damesites sugata (Forbes) & $(1019 a) ; 1109 ; 1219 a 3 ;(1267 a) ; 2506 c ; 2556 \mathrm{fl}$ \\
\hline Damesites sp. & 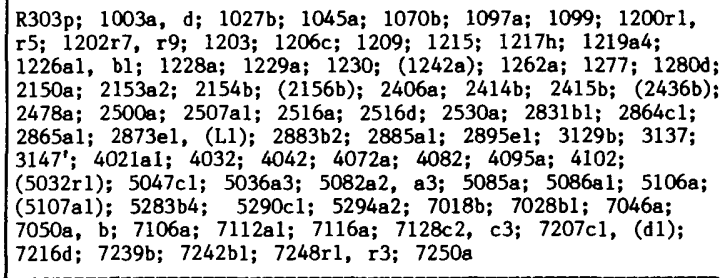 \\
\hline Hauericeras (Gardeniceras) angustum Yabe & $\begin{array}{l}\text { 1115b; 1253b3; 2532e; (2560b1); 2894; 4016p5; 4019p; 4030p; } \\
\text { 4031p; 5007i1; (5029a) }\end{array}$ \\
\hline Hauericeras sp. & $\begin{array}{l}\text { (1060a); 1097a; 1202r7; (1204a); 2564b; 2585a; 2895el; } \\
4007 \mathrm{~b} ; 4010 \mathrm{c} ; 4010 \text { 'p1; 4023c1, cr; 4025a1; 4026a1; 4102; } \\
5007 \mathrm{j} 3 ; 5024 \mathrm{al}, \mathrm{b} ; 5025 \mathrm{~b} ; 7112 \mathrm{al} ; 7158\end{array}$ \\
\hline Yokoyamaoceras kotoi (Jimbo) & $2895 \mathrm{e} 1 ; 7128 \mathrm{c} 2$ \\
\hline Yokoyamsoceras jimboi Matsumoto & $\begin{array}{l}\text { 1269a2; 2153a2; (2414a); 2419a1; 2421a; 2446a2; 2506c; } \\
2507 \mathrm{~d} 1 ; 7055 \mathrm{a}\end{array}$ \\
\hline Yokoyamaoceras sp. & $2411 \mathrm{a} ; 2873 \mathrm{~b} 2, \mathrm{~b} 5, \mathrm{~L} 1 ; 7128 \mathrm{~d} 1 ; 7205 ; 7221 \mathrm{~b} 3 ; 7248 \mathrm{r} 4$ \\
\hline Anapachydiscus sutneri (Yokoyama) & $1262 \mathrm{a} ; 2516 \mathrm{~b} 1 ; 7301 \mathrm{bl}$ \\
\hline $\begin{array}{l}\text { Anapachydiscus deccanesis yezoensis } \\
\text { Matsumoto }\end{array}$ & (2560b1); 7081b; $7128 \mathrm{c} 1$ \\
\hline $\begin{array}{l}\text { Anapachydiscus sp. aff. A. fascicostatus } \\
\text { (Yabe) }\end{array}$ & $1200 \mathrm{r} 5$ \\
\hline $\begin{array}{l}\text { Anapachydiscus (Neopachydiscus) naumanni } \\
\text { (Yokoyama) }\end{array}$ & $(2556 \mathrm{cl})$ \\
\hline Anapachydiscus sp. & 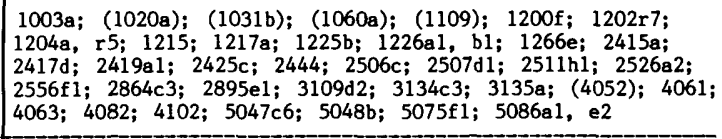 \\
\hline $\begin{array}{l}\text { Menuites pusillus Matsumoto } \\
\text { Menuites japonicus Matsumoto } \\
\text { Menuites sp. }\end{array}$ & $\begin{array}{l}\text { 1029a; 1060a; 1070c; 2560al, b1; 2873b5; 5048b } \\
(1019 a) ; 2531 b 3 ; 7020 d 2 ; 7052 b ; 7053 c 1 ; 7110 a 1 ;(7250 a) \\
1019 a ; 1219 a 8 ; 2560 b 1 ; 5086 a 1\end{array}$ \\
\hline Eupachydiscus haradai (Jimbo) & $\begin{array}{l}\text { 1003a; 1031b; 1060a; 1070b; (1109); 1200a; (1020c); 1221b; } \\
(2516 \mathrm{a}) ; 2864 \mathrm{c} 3 ; 3134 \mathrm{c} 3 ; 3135 \mathrm{a} ; 5040 ;(7013 \mathrm{p} 1) ; 7046 \mathrm{~b}\end{array}$ \\
\hline Eupachydiscus teshioensis (Jimbo) & $1070 \mathrm{~b}$ \\
\hline Eupachydiscus sp. & 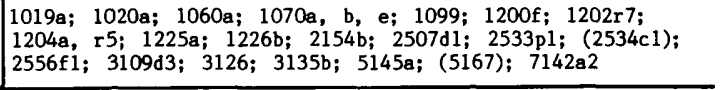 \\
\hline
\end{tabular}


Table 8. Continued.

\begin{tabular}{|c|c|}
\hline Species & Locality \\
\hline Pachydiscidae gen. et sp. indet. & 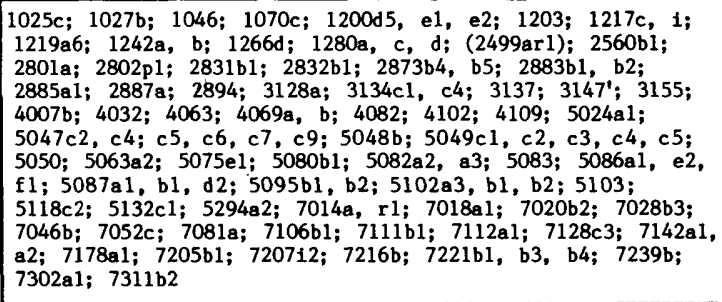 \\
\hline Sornayceras proteus Matsumoto & $2870 a$ \\
\hline Sornayceras omorii Matsumoto & $2506 \mathrm{c}$ \\
\hline $\begin{array}{r}\text { Protexanites (Protexanites) bontanti } \\
\text { shimizui Matsumoto }\end{array}$ & $1200 f, 8 ;(1214 a)$ \\
\hline $\begin{array}{l}\text { Protexanites (Anatexanites) fukazawai } \\
\text { (Yabe and Shimizu) }\end{array}$ & $(1214 c) ; 7239 a$ \\
\hline $\begin{array}{l}\text { Protexanites (Anatexanites) sp. aff. } \\
\text { P. fukazawai (Yabe and Shimizu) }\end{array}$ & $2529 \times 1$ \\
\hline $\begin{aligned} \text { Protexanites (Miotexanites) minimus } & \begin{array}{l}\text { minisumoto } \\
\text { Matsum }\end{array}\end{aligned}$ & $\begin{array}{l}\text { 1204a; (1267d); 2895el; 3126; 4082; 5047c7; 5049c4; } \\
(5132 \mathrm{cl}) ; 7207 \mathrm{cl}\end{array}$ \\
\hline Protexanites sp. & $(5086 a 1)$ \\
\hline $\begin{array}{r}\text { Paratexanites (Paratexanites) sp. aff. } \\
\text { P. orientalis (Yabe) }\end{array}$ & $(1269 \mathrm{al}) ; 1280 \mathrm{a}$ \\
\hline $\begin{array}{l}\text { Paratexanites (Paratexanites) compressus } \\
\text { Matsumoto }\end{array}$ & $5047 c 8$ \\
\hline $\begin{array}{l}\text { Paratexanites (Paratexanites) muramotoi } \\
\text { Matsumoto }\end{array}$ & $2518 \mathrm{p} 1$ \\
\hline Plesiotexanites kawasakii (Rawada) & $\begin{array}{l}(1200 \mathrm{r} 2) ; 1204 \mathrm{rl} ; 1214 \mathrm{~b} ; 1219 \mathrm{a} 4,(\mathrm{a} 7) ; 1251 \mathrm{~b} 3 ;(2516 \mathrm{a}) ; \\
2525 \mathrm{p} 1 ;(2556 \mathrm{f} 3) ; 3128 \mathrm{a} ; 3134 \mathrm{c} 3 ; 5048 \mathrm{a} ; 7052 \mathrm{~d} ; 7080 \mathrm{e}\end{array}$ \\
\hline Plesiotexanites pacificus (Matsumoto) & $\begin{array}{l}\text { 1200f; 1241b; 2511b; }(2516 \mathrm{c}) ;(4046 \mathrm{p}) ; 4052 \mathrm{pl} ;(5049 \mathrm{c} 2) ; \\
\text { 5087b1; 5133al; 5144a }\end{array}$ \\
\hline Plesiotexanites shiloensis (Young) & $(5047 c 6)$ \\
\hline Plesiotexanites (Eutexanites) sp. & $(1217 \mathrm{~b}) ; 2886 \mathrm{~b} 1$ \\
\hline Plesiotexanites sp. & $1200 \mathrm{a} ; 1219 \mathrm{~b} 1 ; 5082 \mathrm{a} 2$ \\
\hline Texanites quinquenodosus (Redtenbacher) & $1267 a$ \\
\hline $\begin{array}{l}\text { Texanites collignoni Klinger and Kennedy } \\
\text { Texanites amakusensis (Yabe) }\end{array}$ & $\begin{array}{l}(1266 \mathrm{cl}) ;(1267 \mathrm{~d}) ;(1271 \mathrm{~b}) ;(1280 \mathrm{~b}) ;(2406 \mathrm{~b}) ;(2418 \mathrm{a}) \\
(2802 \mathrm{pl})\end{array}$ \\
\hline Texanites sp. & $1262 a ; 4069 b$ \\
\hline Submortoniceras condamyi (Collignon) & $(7013 a) ; \quad(7302 a 1)$ \\
\hline $\begin{array}{l}\text { Haboroceras haboroense gen. et sp. nov. } \\
\text { Haboroceras sp. aff. H. haboroense sp. nov. }\end{array}$ & $\begin{array}{l}\text { 1200f; 1204a; 1219a6; 3135c; 4069a; 5047c7; 5049c4; 5086e2 } \\
2873 \mathrm{b5}\end{array}$ \\
\hline Texanitinae gen. et sp. indet. & 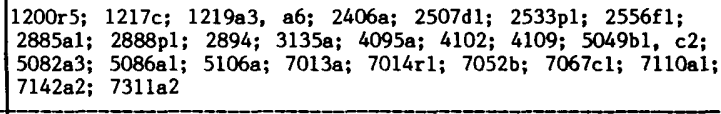 \\
\hline jaw of ammonites & 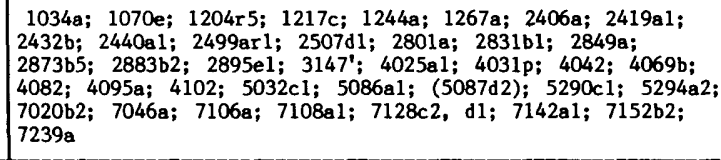 \\
\hline jaw of coleoidea & 1242b; 4032; 5086e2; 7050b; 7132a; 7216b \\
\hline
\end{tabular}

